\title{
Late Ordovician molluscs of the central and eastern Anti-Atlas, Morocco
}

\section{Ebbestad, Jan Ove R.}

The Geological Society of London 2022

Ebbestad, J O R , Polechová , M , Kröger , B \& Gutiérrez-Marco , J C 2022 , Late Ordovician molluscs of the central and eastern Anti-Atlas, Morocco . in A W Hunter, $\mathrm{J} J$ Álvaro , B Lefebvre , P van Roy \& S Zamora (eds), The Great Ordovician Biodiversification Event : Insights from the Tafilalt Biota, Morocco . Special publication of the Geological Society of London, no. 1 , vol. 485 , The Geological Society of London , London , pp. 237-296 . https://doi.org/10.1144/SP485.9

http://hdl.handle.net/10138/325371

https://doi.org/10.1144/SP485.9

unspecified

acceptedVersion

Downloaded from Helda, University of Helsinki institutional repository.

This is an electronic reprint of the original article.

This reprint may differ from the original in pagination and typographic detail.

Please cite the original version. 


\section{Late Ordovician molluscs of the central and eastern Anti-Atlas,}

\section{Morocco}

Jan Ove R. Ebbestad ${ }^{1 *}$, Marika Polechová ${ }^{2}$ Björn Kröger ${ }^{3}$ \& Juan Carlos Gutiérrez-Marco ${ }^{4}$

${ }^{1}$ Museum of Evolution, Uppsala University, Norbyvägen 16, SE 75236 Uppsala, Sweden ${ }^{2}$ Czech Geological Survey, Klárov 3, 11821 Prague 1, Czech Republic ${ }^{3}$ Finnish Museum of Natural History, University of Helsinki, P.O. Box 44, Fi-00014, Helsinki, Finland

${ }^{4}$ Instituto de Geociencias (CSIC, UCM), and Departamento de Geodinámica, Estratigrafía y Paleontología, Facultad CC. Geológicas, José Antonio Novais 12, E-28040 Madrid, Spain *Corresponding author (e-mail: jan-ove.ebbestad@em.uu.se)

Abstract: More than 30 species of tergomyan, gastropod, bivalve and cephalopod molluscs are described from the Late Ordovician of central and eastern Anti-Atlas, Morocco. For the cephalopods this represent the first systematically known taxa of the region. Tergomyans and gastropods are most common in the more shaly part of the Lower Ktaoua Formation, while bivalves are more frequent in the sandy part of the Lower Second Bani Formation. A southern Gondwana aspect is evident for the tergomyan, gastropod, and bivalve assemblages, sharing many taxa with Bohemia, while no clear signal is present for the cephalopods. The latter reflects insufficient knowledge of the fauna of large parts of these areas. The widely recognized Holopea? antiquata is transferred to the genus Radvanospira gen. nov.; other new gastropod taxa include Allossospira gen. nov., Tritonophon grandis sp. nov., Radvanospira baniensis sp. nov., and Lophospira latilabra sp. nov. Most of the diverse bivalve fauna and the few cephalopods are left in open nomenclature but new taxa include the bivalve Praenucula pojetai sp. nov., and the cephalopods Wadema tattai sp. nov. and Tafadnatoceras 
tiouririnense gen. et. sp. nov. The Late Ordovician bivalves from Morocco are dominated by pteriomorphs and protobranchs, inhabiting infaunal, semi-infaunal and epifaunal niches.

Recently, a rare, exceptionally preserved aculiferan mollusc from the Early Ordovician of Morocco provided insight into the early evolution of the Mollusca and the oldest common ancestor of the group (Vinther et al. 2017). The shell bearing molluscs underwent an early radiation and evolution during the Cambrian with (for example) the advent of torsion in the gastropods and the late Cambrian appearance of a cephalopod phragmocone, but also the development of true scaphopods during the Late Palaeozoic (Peel 1991, 2006; Engeser \& Riedel 1996; Frýda et al. 2008; Landing \& Kröger 2012). Although the disparity of molluscs throughout their evolutionary history is astounding, the molluscan body plan also exhibit a tendency to convergence early in their evolution (see for instance Peel 2006; Vinther et al. 2012). When preservation is poor, which is often the case with molluscan fossils, owing to their original aragonite composition of the shell in many groups, similar gross morphologies may make it difficult to elucidate a meaningful phylogeny.

During the Great Ordovician Biodiversification Event (GOBE) molluscs underwent a truly epic radiation and increase in diversity (Webby et al. 2004). Our understanding of this radiation within the molluscs remains poor. Reasons including poor preservation, a disparate and patchy record for many groups and a lack of data from several geographical areas. The present study contributes to our understanding of the latest phase of the GOBE, reviewing and updating the taxonomy and distribution of the Late Ordovician mollusc classes Tergomya, Gastropoda, Bivalvia, and Cephalopoda of the central and eastern Anti-Atlas of Morocco (Fig. 1), presenting more than 30 taxa including several new genera and species. Termier \& Termier (1950) were the first to describe and illustrate Ordovician molluscs (gastropods, bivalves, rostroconchs, and cephalopods) from Morocco and apart from a few 
notable works, very few comprehensive studies have appeared since then. Most of the tergomyan, gastropod, and cephalopod specimens are from the shale and sandstone dominated Ktaoua Group (Lower Ktaoua, Upper Tiouririne and Upper Ktaoua formations) while the bivalves typically occur in the more sandy facies of the Lower Second Bani Formation (Fig. 2). For geological background and stratigraphy see Álvaro et al. (this volume).

\section{Mollusc groups in the Late Ordovician}

Tergomya and Gastropoda. The global diversity of Ordovician tergomyans and gastropods (TG) reflects the prevalence of records from certain palaeoareas, such as Baltica, Bohemia, Laurentia, and North China. By and large this is a consequence of monographic treatments that have focused on the faunas of these particular areas. Both tergomyans and gastropods show high endemicity during the whole of the Ordovician. The lowest endemicity is during the Katian, coinciding with the highest abundance of these molluscs (Frýda et al. 2008;

Ebbestad et al. 2013b and references therein). With a few exceptions, Hirnantian records of these molluscs are paltry, making any new data from this time interval valuable. Four episodes of elevated radiation and origination of gastropods may be identified during the Ordovician (Frýda \& Rohr 2004); the highest rate of extinction was shown to occur during the Hirnantian, although this is probably amplified by the poor fossil record noted above.

Nearshore shallow water TG faunas were susceptible to sea level changes and possible habitat restrictions (Novack-Gottshall \& Miller 2003), which may in part explain some of the fluctuations in the extinction rate, but increasing knowledge of deeper water assemblages will certainly modify this picture (see e.g. Ebbestad et al. 2013a).

Frýda et al. (2008) emphasized the many problems with our current understanding of e.g. gastropod phylogeny, suggesting that studies of specific shell characters as well as the development of protoconch morphologies will provide tools with which to resolve the higher 
group relationships. Unfortunately, protoconchs are not preserved in the material described but the well-preserved teleoconchs provide some insight into these relationships.

Moroccan tergomyan and gastropod faunas show affinities with those of the IberoArmorican faunas. This is most evident for the Early Ordovician (Ebbestad 2016), while during the Late Ordovician Sinuitopsis neglecta Barrande in Perner, 1903, Tritonophon peeli Horný, 1997c, Nonorios pater (Barrande in Perner, 1903), and Holopea antiquata (Barrande in Perner, 1903) are shared with Bohemia. Tritonophon is otherwise widespread, while Nonorios can also be found in the Carnic Alps and Iran (Ebbestad et al. 2008).

Palaeogeographically, Bohemia did not cluster with Morocco and the Ibero-Armorican areas in the Katian-Hirnantian. This is most likely to be the consequence of the currently poor quality of the available Hirnantian data (Ebbestad et al. 2013b).

Bivalvia. Bivalves are well known from many parts of the Late Ordovician world; eastern Gondwana (Argentina) (Sánchez 1990, 1999), Baltica (Isberg 1934; Toni 1975), Bohemia (Barrande 1881a-d; Kříž \& Steinová 2009), Britain (Tunnicliff 1982, 1987; Hind 1910; Reed 1944), Kazakhstania (Khalfin 1958; Sinicyna 1979), Laurentia (Caley 1936; Frey 1987; Bretsky 1970; Pojeta 1966), and Siberia (Krasilova 1970, 1979). According to Cope \& Křŕž (2014), Late Ordovician bivalves became cosmopolitan again for the first time since the early Cambrian. During the Cambrian, bivalves are known mainly from shallow carbonate ramps, where they are generally scarce, but occur in different continents. During the Early and Mid Ordovician, bivalves underwent an explosive diversification (Cope 2004), but they occur mainly around Gondwana and were mainly restricted to siliciclastic sediments (Cope \& Babin 1999). The Late Ordovician bivalves occured widespread and they are known from various habitats (Cope 2002), although their familial diversity changed a little from the Early Ordovician (only two families are new in the Late Ordovician, Cope \& Křřž 2014). 
Epibyssate and endobyssate forms of pteriomorphs show evidence of strong radiation (Cope \& Babin 1999). Although evaluations of Late Ordovician bivalves have suffered from widespread over-splitting, Cope \& Křŕž (2014) demonstrated that it can yield some valuable data. A further problem results form the lack of well-described high latitude bivalve faunas from the Late Ordovician, which fetters comparison with mid-low latitude faunas.

Cephalopods. The diversity evolution and palaeogeographic differentiation of Ordovician cephalopod faunas were analysed and reviewed by Kröger \& Zhang (2009) and Kröger (2013). These analyses revealed a global Ordovician diversity increase at the genus level climaxing during the Katian, accompanied by a general decrease in evolutionary rates and a reduced endemicity. In the context of the Moroccan cephalopod species described herein, it is important to note that during the Late Ordovician no characteristic peri-Gondwanan fauna can be currently distinguished. This pattern is most likely to be an artefact consequent on the lack of knowledge of the faunas of large parts of eastern Gondwana in particular. Notably, Wadema, an actinocerid genus known predominantly from low palaeolatitude Gondwana is present in Morocco, suggesting some relationship to faunas as far away as Australia and Thailand. The only known peri-Gondwanan fauna from relatively high palaeolatitudes was described by Ghavidel-Syooki et al. (2015). It contained slender orthocerids, amongst them Isorthoceras bisignatum (Barrande, 1877), which has some similarities to Tafadnatoceras tiouririnense sp. nov. described herein. The former species is also known from Bohemia, which is in agreement with the general picture of a close relationship of the faunas of Armorica, Bohemia, Iberia and Morocco. Currently, too little is known of these faunas for a more detailed comparison. 


\section{Late Ordovician molluscs in the central and eastern Anti-Atlas}

Tergomya and Gastropoda (Figs 4-25). Late Ordovician tergomyans and gastropods of

Morocco are primarily known through the work of Horný (1997e), based on extensive material collected by the French geologist and palaeontologist Jacques Destombes. Material presented by Termier \& Termier (1950) was shown by Horný (1997e) to be highly fragmentary and ill-determined.

The currently recognized fauna appears sparse, and of a low diversity, with a disparate stratigraphical distribution. It consists of a total of 14 species, two of which are tergomyans, five are bellerophontiform gastropods and seven are anisostrophically coiled gastropods (Fig. 2). Some new collections, especially from the Second Bani Group, add invaluable Hirnantian records, such as the large Tritonophon grandis sp. nov., which otherwise represents a widespread genus in the Katian. Revisions of the species Radvanospira antiquata, Allossospira debganensis, and Deaechospira amouguerana demonstrates more clearly the faunal differences between the cold water siliciclastic dominated realms of southern Gondwana and the warm water carbonate dominated equatorial and sub-equatorial settings of Baltica, Laurentia, and Siberia.

Most specimens in this study are preserved as internal or external moulds, very much like contemporary material from peri-Gondwanan successions in the Czech Republic, France, Portugal, and Spain. In many cases the assemblages are dominated by one species, and in certain cases, like the widespread Mid Ordovician Tropidodiscus pusillus Barrande in Perner, 1903, they can be extremely numerous (Horný 1999a).

Bivalvia (Figs 26-30). Ordovician Moroccan bivalves were practically unknown. Termier \& Termier (1950) figured bivalve specimens from Morocco. Babin \& Destombes (1990) provided a brief list of Ordovician bivalves from the Moroccan Anti-Atlas and the first 
photographic illustrations of those forms. Recently, Polechová (2016) revised the evolutionary important Early Ordovician bivalves from the Fezouata Formation. In this paper, the bivalves described by Babin \& Destombes (1990) are revised and compared with newly collected material from Morocco.

Bivalves from Morocco have been described from different localities and stratigraphical units. They first occur in the Early Ordovician (Tremadocian, Floian) Fezouata Formation within the central part of the Anti-Atlas (Termier \& Termier 1950; Babin \& Destombes 1990; Cope 2002; Cope 2004; Polechová 2016). According to Babin \& Destombes (1990), after the Early Ordovician the bivalves are rare and limited to a few specimens that are very often badly preserved. Bivalves are also more widespread in the western, central and eastern AntiAtlas. Babin \& Destombes (1990) figured a few bivalves from the Late Ordovician; Praenucula costae (Sandbian), Phestia? sp. (Sandbian), Praenucula sp. (Hirnantian), Myoplusia? sp. (Sandbian), Palaeoneilo sp. (Hirnantian), and Modiolopsis? sp. (lower Katian). New material of bivalves from Morocco come from both eastern and central AntiAtlas and originate from the upper part of the Upper Ktaoua Formation (Katian) and the Lower Second Bani Formation (latest Katian, Hirnantian) (Fig. 2).

All the bivalves studied are preserved as internal or external moulds. Some internal moulds show excellent preservation with hinge, adductor, pedal and accessory muscle scars all present (e.g. Praenucula pojetai sp. nov., Fig. 26o-q), but generally the preservation is mediocre. Articulated specimens are rare and specimens preserved in butterfly position are not present, suggesting some preburial transport of individuals. By contrast, two specimens of Cleionychia prisca (Fig. 29d-h) are probably preserved in life position. Bivalves in this study are often preserved as isolated specimens, and only the locality Aït Isioul 'north (west of Tagounite) provides several specimens (mainly Modiolopsis) on one bedding plane. Kříž \& Steinová (2009) described the Modiolopsis Community Group from the Late Ordovician of 
Bohemia. The genus Modiolopsis is dominant in many communities from the Early

Ordovician (Babin 1966; Babin \& Hamman 2001) and the Modiolopsis Community Group is characteristic of the shallow, high energy and sandy inner shelf environments.

The Moroccan bivalve associations share some similarities to the Late Ordovician bivalve asociations from Bohemia (Praenucula, Sluha, Modiolopsis, and Myoplusia), Ireland and Baltica (Ambonychia, Cleionychia, Cyrtodonta, and Nuculites).

Some internal moulds contain traces of the ichnofossil Arachnostega, which is often preserved in Ordovician skeletal faunas (Fatka et al. 2011; Lefebvre 2007; Vinn et al. 2014).

Gil Cid \& Lebrón Moreno (2010) found that Arachnostega is not restricted to a specific environment, as it occurs in both, shallow or deeper facies, as well as in siliciclastic and carbonate environments. They are rather indicators of firm muddy, coherent substrates.

Cephalopoda. The Late Ordovician cephalopods of Morocco and of North Africa in general are practically undescribed. The few taxa described herein, represent the first systematically known Late Ordovician cephalopods of the region. Previously, one probable Late Ordovician specimen only, an annulate orthocone, possessing a reticulate shell sculpture was figured as a schematic line drawing under the name Pseudorthoceras? sp. by Termier \& Termier (1950, pl. 35, fig. 1-3) from the Region d'Aït Saadane-Taghbalt; no additional information is available regarding this specimen. Moreover, a regional comparison of the cephalopods, described herein, is problematic because time-equivalent assemblages from areas such as Armorica, Iberia, and Sardinia are yet to be systematically described. The Bohemian Ordovician species described by Joachim Barrande in the $19^{\text {th }}$ century and listed by Marek (1999) are in need of a revision and are not yet sufficiently well figured and described to warrant a full comparison with the material described here. This is probably the main reason 
why taxa closely similar to the ones described herein, are known only from relatively few regions of circum-Gondwana such as Australia and Eastern Asia (see below).

\section{Palaeoecology}

Tergomya and Gastropoda. Whereas several studies have investigated gastropod biofacies distribution and biocommunities (see review in Ebbestad et al. 2013b), fewer studies have focussed on the life habits of Tergmoya (e.g. Horný \& Vizcaïno 1995; Horný \& Peel 1996; Horný 1997e). The latter work discussed life habits of all the Moroccan species of tergomyans as well as the gastropods. The Late Ordovician taxa range in size from the minute Tritonophon to the gigantic Sinuites destombesi and from planispiral to high spired conispiral shell-draggers, and a broad range of life-styles is involved. Perhaps the best studied taxon is Sinuites, which is inferred to have an infaunal or semi-infaunal predatory life style (see Horný 1997e). Several taxa show morphologies that are compatible with a shallow water environment and high energy, like the explanate Bucanopsina and the robust Deaechospira, Allossospira, Nonorios, and Radvanospira. All of these would be epibenthic browsers, scavengers or predators.

Several species show signs of shell repair, presumably from failed predation. This is particularly evident in the large Allossospira debganensis, where multiple repairs are seen in two specimens illustrated here (Fig. 22b \& g), and in a specimens figured by Horný (1997e, pl. 14, figs 1-5. Typically this is a sign of the animal reaching a size-refuge, so that by its large size alone, it will survive more readily and thus accumulate repairs from failed predation (Ebbestad \& Stott 2008). It is also shown in the present study that Deaechospira sp. probably was a clamper, pulling the shell down over the foot to protect the soft part from predation. Repairs are otherwise documented in Deaechospira amouguerana (Figs 17a, g, 18e \& 19b), 
while Horný (1997e) reported injuries in Mid Ordovician Ptychonema marocanum Horný, 1997e.

Bivalvia. Bivalve assemblages from the Late Ordovician of Morocco are quite diversified with 13 taxa known. Most of the specimens are left in open nomenclature, because they do not show enough characters for determination to the species level. According to the methodology of Kř́ž (1999), the bivalve associations from the Early and Late Ordovician were compared (Table 1). The pie diagrams (Fig. 3) follow the methodology of Cope \& Kř́ž (2014) and demonstrate a large change in faunal composition, compared with the Early Ordovician assemblage of bivalves from the Fezouata Formation of Morocco (Polechová 2016). The Early Ordovician association of bivalves of Morocco show only infaunal feeders, while epifaunal feeders are well-represented in the Late Ordovician associations. Heteroconchs completely dominate the Fezouata Formation, whereas during the Late Ordovician protobranchs and pteriomorphs prevail.

\section{Praenucula pojetai sp. nov., Myoplusia sp., Sluha kosoviensis, Nuculites sp., Pseudarca?} sp., and Phestia? sp. are considered infaunal feeders. Praenucula, Myoplusia and Sluha possess well-developed pedal muscle scars and they were probably infaunal deposit feeders. Nuculites was probably an infaunal filter feeder. Modiolopsis, Cyrtodonta and Dceruska were semi-infaunal, probably endobyssate filter feeders but the internal morphology is not wellknown. They show some reduction of the anterior part, a feature characteristic of bysally attached bivalves. Cleionychia and Ambonychia lived epifaunally, showing a prominent byssus. According to Pojeta (1971), ambonychiids were gregarious and large numbers of articulated shells on one bedding plane were described. The specimen of Cleionychia prisca (Fig. 29d-h) is probably recorded in life position. It is associated with brachiopods and 
bryozoans, and seems to be attached to the substrate, nestling between the brachiopods and bryozoans.

\section{Localities}

The new material presented in this study comes from a number of formations and localities which range from the Darriwilian to Hirnantian in the central and eastern Anti-Atlas.

Lithostratigraphic nomenclature follows Destombes (in Destombes et al. 1985; Destombes 2006a) and Álvaro et al. (this volume).

The oldest locality corresponds to the lower part of the Taddrist Formation (First Bani Group) and lies to the SW of Alnif, about $5.8 \mathrm{~km}$ northeast of the town of Aachich n'Ait Azza (geographic coordinates: $30^{\circ} 55^{\prime} 18^{\prime \prime}$ latitude N, $05^{\circ} 14^{\prime} 51^{\prime \prime}$ longitude W). This is the type locality and horizon of two endemic trilobite and echinoderm species (Rábano et al. 2014; Zamora et al. 2015; Reich et al. 2017) and it is the source of Endoceratidae gen. et sp. indet. described below. The age of this horizon is upper Oretanian, a regional stage division roughly equivalent to the upper Darriwilian 2/basal Darriwilian 3 of the global scale (Gutiérrez-Marco et al. 2015, 2017).

The next location is of late Berounian regional age (= late Katian 1 to Katian 2 of the global scale) and corresponds to a lenticular calcareous coquina placed in the upper part of the Upper Tiouririne Formation (Ktaoua Group) represented by an isolated excavation c. $6.5 \mathrm{~km}$ southeast of the city centre of Erfoud (= Arfoud): locality 'Erfoud 2', coordinates $31^{\circ} 24^{\prime} 10^{\prime}$ ' latitude N, $4^{\circ} 10^{\prime} 37^{\prime \prime}$ longitude W (marked E2 in Fig. 1). It contains a rich assemblage of trilobites, cephalopods, gastropods and conulariids of which Radvanospira antiquata and Tafadnatoceras are described here.

Higher in the succession, the next fossiliferous horizon corresponds to the upper part of the Upper Ktaoua Formation (Ktaoua Group), and is represented by richly fossiliferous strata 
containing a typical Mucronaspis termieri-Flexicalymene ouzregui trilobite assemblage. This occurs in nodules at two locations that lie close to each other at Jbel Bou Ingarf, north and south of the Zagora-Tazarine road (Jbel Bou Ingarf 'north', 30 34' 33" latitude N, 5'34' $18^{\circ}$ ' longitude W; Jbel Bou Ingarf ‘south', 30²8' 11” latitude N, 5²6' 0” longitude W). Material from the first locality comes from below the level erroneously designated as the 'Ouzregui bed' by Loi et al. (2010), which in fact corresponds to the single and discontinuous ferruginous marker horizon mentioned by Destombes (2006b, p. 35), containing 'Dreyfussina' struvei and Amphitryon. The noduliferous strata with Flexicalymene ouzregui and other abundant trilobites, different from the taxa mentioned above, occur in a 30-40 m stratigraphic range below this horizon marking the top of the Upper Ktaoua Formation (Gutiérrez-Marco et al. 2017, p. 272). Besides the trilobites, molluscs occur scarcely and other fossil groups are very rare in the nodules at these localitites. Deaechospira, Sinuites, Wadema, and an ormoceratid are recognized from here. According to Gutiérrez-Marco et al. (2017, fig. 5), the age of the upper part of the Upper Ktaoua Formation is Kralodvorian, equivalent to Katian 3 4 of the global scale (Bergström et al. 2009).

The remaining material comes from different localities placed in the Lower Formation of the Second Bani Group with excellent sections to the west and south of the town of Tagounite (from $30 \mathrm{~km}$ southwest to $50 \mathrm{~km}$ southeast of the city of Zagora, Central Anti-Atlas). With the exception of a single older horizon in one section, all the other sections are regarded as being of a of Hirnantian age based on the occurrence of a typical Mucronaspis-Hirnantia faunal assemblage. This may occur in association with the studied molluscs, or from beds immediately below or above (Destombes et al. 1985, figs 37 \& 38; Gutiérrez-Marco \& Vinn 2018). The most fossiliferous sections lie near the eastern end of the quartzitic cuesta of Ait Isioul, about $33.4 \mathrm{~km}$ west-north-west of Tagounite. Here and above the local outcrops of the Ktaoua Group, the sandstones and bioturbated shales of the Lower Second Bani Formation 
form a prominent escarpment (bani= mountain), and the two main sections nearby are named

Aït Isioul 'north' and 'south', being respectively placed in the eastern and western banks of the same small valley running to the north into the Oued Moulili. In the former locality (c. $30^{\circ}$ 04' 41" latitude N, $05^{\circ} 54^{\prime} 25^{\prime \prime}$ longitude W), Hirnantian bivalves occur abundantly in coquinoid sandstones belonging to bed 'F' of the Lower Second Bani Formation as defined by Destombes et al. (1985) and Destombes (1983: an unpublished version of the incompletely published manuscript of Destombes 2006b). This is well above the FAD of the Hirnantia Fauna (Colmenar in Gutiérrez-Marco \& Vinn 2018). The bivalves Nuculites, Modiolopsis, Dceruska, Ambonychia, Cleionychia, and Cyrtodonta are known from here.

The complementary section Aït Isioul 'south' is located $800 \mathrm{~m}$ southwest of the former and also ranges from the quartzitic horizon ' $\mathrm{G}$ ' (lower) to horizon ' $\mathrm{F}$ ' (upper) of Destombes, lying at about $30^{\circ} 04^{\prime} 27^{\prime \prime}$ latitude $\mathrm{N}, 5^{\circ} 54^{\prime}$ '53" longitude W. This steeply-inclined section has been studied in detail and starts with beds of late Kralodvorian (= late Katian 4) age. These range from the base of the formation to about $6 \mathrm{~m}$ above horizon ' $\mathrm{G}$ ', thus comprising the first studied fossiliferous beds T1 and T2 (above 'G') bearing some trilobites and bivalves. Fossil horizons T4 (coincident with the FAD of the Hirnantia brachiopod fauna) and T5 are placed respectively 11.5 and $14.8 \mathrm{~m}$ above the top of the horizon ' $\mathrm{G}$ ', having yielded the gastropods Tritonophon and Radvanospira and the bivalves Ambonychia, Cleionychia, and Dceruska. Higher up in the section, several levels containing large bivalves are recorded from the quartzitic horizon ' $F$ ', whose base is placed about 40-60 $\mathrm{m}$ above the top of ' $\mathrm{G}$ ' and which also bears a very abundant Hirnantia brachiopod fauna.

Finally, two other sections in the Hirnantian beds of the Lower Second Bani Formation also yielded remains of the large bivalve Cyrtodonta and the smaller bivalve Cleionychia prisca. The first section, provisionally designated the "Foum el Fehamya section" is located $10.8 \mathrm{~km}$ west of the Foum el Fehamiya pass and $27 \mathrm{~km}$ northwest of Tagounite $\left(30^{\circ}\right.$ 
02' 55” latitude N, 5’ 51' 13.4” longitude W). It was studied by Havlíček (1971), Destombes et al. (1985), Destombes (1983), and Mergl (1983), and was attributed to somewhat higher beds (quartzitic horizons ' $D$ ' and ' $C$ '), but still associated with the Hirnantia Fauna.

The second locality lies east of the road to Mhamid on the mountain Pass south of Tagounite (29 $54^{\prime}$ ' $33.5^{\prime \prime}$ latitude N, 5' 36' 04' longitude W), where a 'float' specimen of the large bivalve Nuculites sp. was recorded from strata lying below the first of the glacial unconformities recorded within the Second Bani sandstone Group. (i.e., below the base of the Upper Second Bani Formation).

Horný (1997e) referred to Destombes’ localities and presented a detailed list with names and coordinates. This information is not repeated here, and only the Destombes locality number is given here.

\section{Material and methods}

The material described and discussed herein comes partly from extensive material collected by the French geologist and palaeontologist Jacques Destombes. New material has been added by J.C. Gutiérrez-Marco from several fieldtrips to Morocco. Most of the tergomyan and gastropod specimens were described by Horný (1997e), while part of the bivalve material was described by Babin \& Destombes (1990). Destombes (2006a) re-illustrated some of the material described by these authors.

All the figured tergomyans, gastropods, bivalves, and some of the cephalopods were coated with ammonium chloride before being photographed. All bivalve specimens were measured (length, height, and width of the shell, and in some specimens also the angular relationship between different parts of the shells). The methodology of Stanley (1970), Kř́žz (1999) and Cope \& Křriž (2014) was used for the palaeoecological interpretation of the bivalves. All bivalve specimens were systematically determined and statistically analysed to 
find their numerical and ranked abundance. Abbreviations Bivalvia. $\mathrm{V}=$ valve, $\mathrm{L}=$ length of the shell, $\mathrm{H}=$ height of the shell, $\mathrm{W}=$ width of the shell, $\mathrm{W} / 2$ = width of one valve (Kř́rž 1969). Measurements of whorl parameters in tergomyans and gastropods follow Peel (1974) and Ebbestad (1999). All linear measurements are in millimetres.

\section{Systematic Palaeontology}

Naming of taxa for each systematic group is credited to the main authors of the group only;

Ebbestad \& Gutiérrez-Marco for Tergomya and Gastropoda, Polechová \& Gutiérrez-Marco for Bivalvia, and Kröger \& Gutiérrez-Marco for the Cephalopoda. The classifications used by Horný (1997b, 1997c, 2002) for the Tergomya and the bellerophontoid Gastropoda, Wagner (2002) and Frýda \& Bouchet (2005) for the anisostrophic Gastropoda, and Carter et al. (2011) for the Bivalvia are adopted here. Synonym lists follow the reccomendations by Matthews (1973) Specimens are deposited in the following collections: the University of Lyon 1, France (FSL ); the Museo Geominero, Madrid, Spain (MGM); the Department of Palaeontology in the National Museum, Praha 9, Czech Republic (NM); the Cadi-Ayyad University, Marrakesh, Morocco (AA). Non-Moroccan specimens from other collections are mentioned as follows: BGS GSM (British Geological Survey, Keyworth, Nottingham), NIGP (Nanjing Institute of Geology and Palaeontoogy, Nanjing, China), and UM K Ulster Museum, Belfast, Ireland).

LSID: http:// zoobank.org/\#\#\#

Phylum Mollusca Linné, 1758

Class Tergomya Horný, 1965

Family Cyrtolitidae Miller, 1889 
Type species. By subsequent designation of Cossmann (1904, p. 108), Sinuitopsis neglecta

375

Barrande in Perner, 1903, pp. 68-71, text-figs 42-46, pl. 85, fig. 11 \& pl. 88, figs 28-30, 3840, from the Upper Ordovician (Katian Stage) Zahořany Formation at Loděnice, Prague Basin, Czech Republic.

Sinuitopsis neglecta Barrande in Perner, 1903

(Fig. 4a-h)

Material. 22 specimens, listed by Horný (1997e).

Localities and horizons (Moroccan specimens only). Destombes localities 86, 88, 134, 628, 899, 1265, 1778, central and eastern Anti-Atlas, Morocco. Lower Ktaoua and Upper Tiouririne formations, Sandbian and Katian stages.

Remarks. The tergomyan Sinuitopsis is a characteristic element of the Mid to Late Ordovician of the Bohemia, Czech Republic, with four species known; S. evoluta (Perner, 1903) from the Šárka Formation (Darriwilian), Sinuitopsis sp. sensu Horný (1997b) from the Dobrotivá Formation (Darriwilian), the type species $S$. neglecta from the Zahorany Formation (Katian), and S. hornyi Marek, 1963 from the Kosov Formation (Hirnantian). Horný (1997e, 1999b) mentions other unnamed species of the genus in Bohemia. The species $S$. nodosa Perner, 1903 co-occurs with the type species and was considered its junior synonym by Horný (2002). Sinuitopsis neglecta is common in the Lower Ktaoua Formation in the eastern Anti-Atlas (Horný 1997e), and the most typical specimens are re-illustrated here (Fig. 4). Villas et al. 
(2006) reported the species in the uppermost part of the Lower Ktaoua Formation at Alnif in eastern Anti-Atlas (Katian), where it co-occurs with the (here revised) gastropods Radvanospira antiquata (Barrande in Perner, 1903) and Deaechospira amouguerana (Horný, 1997e). According to Horný (1997e) in Morocco S. neglecta is even associated with the gastropods Nonorios pater (Barrande in Perner, 1903), Tritonophon peeli Horný (1997c), and Bucanopsina calypso (Perner, 1903). In Bohemia, Czech Republic, the latter also co-occurs with Sinuitopsis neglecta.

Dzik (1981) figured a specimen of $S$. neglecta from an erratic boulder of Backsteinkalk found in Poland. Erratics of this type came from Sweden or Baltic states and are no younger than mid-Sandbian (Schallreuter 1970), thus this record is older than the Czech Republic and Moroccan occurrences. Horný (1997e) further discussed the possibility that Pharetrolites? tumidus (Koken, 1897) and P.? elegans (Koken in Koken \& Perner, 1925) from the Dariwillian Elnes Formation, Oslo Region, Norway could be species of Sinuitopsis. Yochelson (1963) redescribed these species and tentatively assigned them to the Silurian Pharetrolites Wenz, 1943.

Bellerophon (Sinuitopsis) avunculus Hadding, 1913 from the Darriwilian Andersön Formation at Andersön, Jämtland, Sweden, belongs with Tropidodiscus and so is also most likely the case with the poorly preserved B. (Sinuitopsis) consobrinus Troedsson, 1918 from the Katian Lindegård Mudstone, Scania, Sweden. Yochelson (1964) discussed both species and although no firm generic assignment was made, he pointed out that the latter species possessed a dorsal median band thus excluding it from the sinuate Sinuitopsis. Bellerophon (Sinuitopsis?) subtrilobatus Troedsson, 1918, from the same unit, was shown to be a species of Tritonophon by Ebbestad et al. (2008).

Kobayashi (1934) described Sinuitopsis kochiriensis from the Darriwilian Jigunsan Formation, South Korea, showing a small, paucispiral shell with strong ribs and a V-shaped 
median anterior sinus without a median dorsal band. The taxon is not readily comparable with Sinuitopsis, or other sinuate taxa for that matter, and may constitute a new genus. Sinuitopsis cf. kochiriensis sensu Kobayashi (1959) from the Floian La Nga Formation, Tarutao Island, southern Thailand, is most likely Peelerophon oehlerti (Bergeron) according to Jell et al. (1984).

An interesting occurrence of Sinuitopsis is S. congruens Reed, 1920 from the Sandbian Pumphouse Member of the Balclatchie Formation in Girvan, Scotland, as this would represent marginal Laurentia. However, other typical peri-Gondwanan form also make their appearance in the Girvan succession. Horný $(1963,2002)$ and Ebbestad (2008) discussed the presence of the characteristic peri-Gondwana genera Carcassonnella Horný \& Peel, 1996 and Grandostoma Horný, 1962 in the Katian of Girvan, and Ebbestad et al. (2013b) speculated that this could relate to transgressive episodes that could introduce peri-Gondwanan genera to Girvan via Baltica.

Although post-Ordovician species have been named, Sinuitopsis is likely to be restricted to the Ordovician. Examination of Sinuitropsis subrectangulatus Pitcher, 1939 from the Silurian of the Welsh Borderland shows a paucispiral shell with barely contiguous whorls. Although the apertural lip is not preserved, the species is better placed with Pharetrolites Wenz, 1943 (see Peel 1975 for a discussion on Pharetrolites). The Devonian Bellerophon acutilira Hall, 1861 was placed with Sinuitopsis by Rollins \& Batten (1968), a position viewed with scepticism by Horný (1991). Blodgett et al. (1999) eventually placed the species with Sinuitina Knight, 1945.

Horný (1997e, p. 2, figs 5 \& 6) described two specimens of Sinuitopsis? sp. from the Lower Ktaoua Formation at Destombes locality 399, eastern Anti-Atlas. These differ from $S$. neglecta in having regular commarginal ribs in the early whorls instead of undulating ribs. These specimens are otherwise flattened and incomplete and are not re-illustrated here. 
Type species. By original designation, Atlantophon maider Horný, 1997e, p. 53, pl. 8, figs 8-

11, from the Upper Ordovician (Katian Stage) Lower Ktaoua Formation at Destombes locality

Material. Holotype specimen only (NM S2673), figured herein as Fig. 5a-e.

460

Locality and horizon. Destombes locality 882, eastern Anti-Atlas, Morocco. Lower Ktaoua

463

Formation, Katian Stage.

(Fig. 5a-e)

\section{Formation, Katian Stage.}

Remarks. This enigmatic taxon is known solely from the type species. It was described in detail by Horný (1997e) and is re-figured here, high-lighting various aspects of the morphology. The left half of the shell is almost covered by matrix. Horný (1997e) remarked that the specimen was depressed and crushed. In posterior and dorsal views (Fig. $5 \mathrm{~b} \& \mathrm{c}$ ) it is clear that the specimen is laterally compressed, which is also suggested by irregularities on 469 the body whorl. The dorsal lobe is obscured at the posterior of the visible shell (see arrow 1 in 470 Fig. 5b). Furthermore, the transition from the median lobe to the whorl on the left side is 471 placed much higher than on the right side (see arrows marked 2 in Fig. $5 b$ \& c); the growth 
472 lines are visible in the groove between the shell and the matrix. The lack of a lobe on the

473 earlier whorls and the high placement on the left side is due to the compressional deformation

474 of that part of the shell having been sheared and moved up (see white arrow in Fig. 5b: the

475 compressional suture runs adapberturally, cutting across the median lobe towards the left).

476 The compaction and deformation probably contribute to an accentuation of the median lobe,

477 perhaps even more so than acknowledged by Horný (1997e). Furthermore, near the aperture 478 the trilobation is less marked (see white arrow in Fig. 5c).

479 Atlantophon therefore seems to be less strongly trilobate than for instance Tritonophon 480 and the whorls are probably more lanceolate than reniform with the shallow U-shaped sinus 481 on the median lobe (see tentative outline drawn on specimen in Fig. 5c). The overall shell 482 morphology would thus resemble that of Sinuitopsis, although with an accentuated median 483 dorsum, a more shallow median apertural sinus, and an ornamentation of distinct tiled increments with a raised edge adaperturally.

Horný (1997e) compared Atlantophon with the trilobed Bucanella Meek from the Tremadocian of North America. The concept of Bucanella formulated by Koken \& Perner (1925) is essentially eroded, with most of the originally assigned species that were placed in their sub-family Bucanellinae now being transferred to other genera (such as $B$. quadrisulcatus (Reed) herein being transferred to Plectonotus). Frýda \& Bouchet (2005) elevated the Bucanellinae to family level, attributing the name to Koken (1925). However, as explained by Ebbestad (1999) that work, and in this case the family name, must be attributed to Koken \& Perner (1925).

Peel (1974) showed that Bucanella nana Meek, the type species, may in fact have a bordered median dorsal band instead of only the dorsum being sinuated. In light of the discussion herein, similarities between Bucanella nana and Atlantophon seems merely 
504

505

506

507

508

509

510

511

512

513

514

515

516

517

518

519

520

convergent morphology and Atlantophon can therefore neither be placed in the Plectonotinae nor the Bucanellidae.

Until new and better material of Atlantophon is discovered the family placement remains unresolved. Because of the trilobation, and comparison with the Plectonotinae, it is tacitly understood that this taxon had a pair of laterally placed ctenidia coinciding with the position of inhalant currents, while the median placed elevation was the site of the exhalant current and the anus as a result of torsion.

\section{Superfamily Bellerophontoidea McCoy, 1852}

Family Sinuitidae Dall in Zittel \& Eastman, 1913

Genus Sinuites Koken, 1896

Type species. By subsequent designation of Bassler (1915, p. 1159), Bellerophon bilobatus Sowerby in Murchison, 1839, p. 643, pl. 19, fig. 13, from the Upper Ordovician (Sandbian Stage) Horderly Sandstone at Horderley, Shropshire, England.

Sinuites destombesi Horný, 1997e

(Figs 6a-f, 7a-f \& 8)

Material. 30 specimens mentioned by Horný (1997e) and five new specimens added herein (specimens MGM-6963X-MGM-6966X).

Localities and horizons. Destombes localities 750, 885, 901, 1078, 1080, 1109, 1132, 1624, 1651, 1791 (see Horný 1997e) and Jbel Bou Ingarf ‘south’ (the MGM specimens listed under 
material), central and eastern Anti-Atlas, Morocco. Upper Ktaoua and Lower Second Bani formations, Katian to Hirnantian stages.

Remarks. Horný (1997e) erected this species, based on the exceptionally large size of adult specimens (Fig. 6). It bears finely reticulated shell ornamentation (Fig. 7), which is seen in a number of species of Sinuites (see discussion in Horný 1997e). Records of the genus in the cold-water settings of Armorica, Iberia, and Bohemia flourish in the literature. Often they appear under the name Sinuites bilobatus (Sowerby in Murchison, 1839), but a number of species are named (see Horný 1963; Gutiérrez-Marco 1984; Sá 2008). Except for Sinuites sowerbyi Perner, 1903 from the older Tachilla Formation (Darrwilian), S. destombesi is the only named species of the genus in the Ordovician of Morocco.

Besides the gross morphology, specimens of $S$. destombesi preserve a number of morphological details. The reticulate shell structure shows densely spaced co marginal ribs crossed by subordinate spiral lines. The reticulation can be subdued or more distinct on the median sinus (Fig. 7a \& c) and is more densely spaced on the lateral sides of the shell than towards the dorsum (Fig. 7b \& d). At the umbilici the lip does not fill the space but forms a deep depression with a labro-umbilical ridge (Fig. 7e). Two deposits are seen in or close to the umbilical area. Firstly, the inductura in the umbilici, a lamellar deposit that would correspond to the parietal inductura or parietal callus at the inner part of the lip at the umbilicus in conical shells. The second type of deposit was called the subinductura by Horný (1996), and represents deposits laid on top of the original shell outside the umbilici (Fig. 7d \& f). The subinductura is deposited underneath the inductura proper. Sometimes the subinductura preserves a slightly raised ring-like structure which was called the subinductural vallum by Horný (1996) pertaining to the rampart of roman fortifications (see Horný 1997e, pl. 6, fig. 2). Secondary shell deposits have been used to distinguish between sinuitid genera 
(i.e. Frýda \& Gutiérrez-Marco 1996) but as pointed out by Ebbestad et al. (2013a) secondary shell deposits may not be a derived feature, but could equally well be a broadly shared sinuitid characteristic, or even an ecological response in some sinuitid groups.

Horný (1997e) illustrated four specimens in which the myostracum was preserved. This appears as a thin, entire layer reflecting the area where the adductor muscle of the head-foot mass attached to the umbilical area of the shell.

A cross-section of $S$. destombesi shows a very low umbilical angle (sensu Ebbestad 1999) of about only $6^{\circ}$. Whorl height of the last whorl is slightly more than $2 / 3$ of whorl width, while for the penultimate whorl this is slightly lower than $2 / 3$ of whorl width. The rate of whorl expansion and whorl expansion at half whorls (sensu Peel 1974) is 2.7 and 4.4 respectively (Fig. 8). Thus, the shell is tightly coiled with a fairly low rate of expansion that increases slightly at maturity with a whorl that expands more dorsally than laterally.

Of the cold-water peri-Gondwanan species $S$. destombesi is most similar to S. hispanicus (Born, 1918) from the Darriwilian of Spain. Apart from attaining a large size, the contemporaneous species show similar reticulate ornamentation and the slight flattening of the median dorsum. Horný (1997e) pointed out that S. destombesi does not show constrictions across the internal mould of the body whorl, which sometimes occur in S. hispanicus. However, this is not a feature that seems to have phylogenetic importance. 
569

570

571

572

573

574

575

576

577

578

579

580

581

582

583

584

585

586

587

588

589

590

591

592

Type species. By original designation, Kokenospira (Tritonophon) trimetra Öpik, 1953, p. 20, pl. 7, figs 52-54, from the Lower Silurian (Llandovery) Wapentake Beds (lower part 'Illaenus Band'), Heathcote, Victoria, Australia.

Tritonophon peeli Horný, 1997c

(Fig. 9a \& b)

Material. Five specimens mentioned by Horný (1997e).

Localities and horizon. Destombes localities 399 and 899, eastern Anti-Atlas, Morocco.

Lower Ktaoua Formation, Sandbian? to Katian stages.

Remarks. The Ordovician distribution and species of this taxon was reviewed by Ebbestad et al. (2008). It is widespread in several peri-Gondwanan areas, Baltica, Avalonia, Kazakhstan, and Laurentia, ranging in age from Darriwilian to Hirnantian (herein). Owing to generally poor preservation, usually only the small and distinctly trilobed internal moulds are known. Although this leaves some degree of uncertainty with regards to affinity, the trilobed morphology, small size and narrow umbilici readily distinguish these kind of shells. Another trilobed Ordovician genus is Bucanella Meek, where the umbilical angle is greater than in Tritonophon or Plectonotus and it does not seemingly have a dorsal median band (but see discussion on Atlantophon maider). As such, the species 'Bucaniella' [= Bucanella $]$ quadrisulcata Reed, 1920 from the Silurian (Llandovery) of Wales should be transferred to Plectonotus, owing to the general shell morphology and the narrow outline of a dorsal median band, and it is here recombined as Plectonotus quadrisulcatus (Reed). 

lines curving gently back on the whorl towards the median raised keel, and the border of the median dorsal band (Fig. 9). Horný (1997e) compared it with the type material from Bohemia,

Czech Republic, where the species has a long range. Horný (1997c) suggested that a

specimens attributed to 'Bucaniella' bohemica Perner, 1903 (now T. bohemicus) by Termier \& Termier (1950, pl. 131, fig. 3) from a locality $3 \mathrm{~km}$ north of Taouz, eastern Anti-Atlas, could belong to T. peeli. In Bohemia T. bohemicus occurs in the Kralodvorian (upper Katian

600

601

602

605

606

607

608

609

610

611

612

613

614

615

616

617 and lower Hirnantian).

Frýda (1999) followed Wahlman (1992) and placed the subfamily Plectonotinae in the family Bucaniidae while Horný (1997e) and Ebbestad et al. (2008) placed it with the family Bellerophontidae. Frýda (1999) pointed out the many uncertainties at the family-level classification within the bellerophontoidean gastropods.

Tritonophon grandis sp. nov.

(Fig. 10a-h)

Holotype. Specimen MGM-6967X figured herein as Fig. 10a-e.

Diagnosis. Large Tritonophon with shell nearly as wide as long, median lobe broad with median band slightly narrower than the lobe.

Derivation of name. From latin grandis, meaning large or grand, pertaining to the impressive size of the species.

Material. Four paratype specimens preserved as internal moulds (MGM-6968X-MGM- 
Type locality and horizon. Aït Isioul 'south', West of Tagounite, central Anti-Atlas, Morocco.

Description. Shell large with maximum preserved shell length of $\sim 10 \mathrm{~mm}$; max shell width $\sim 8$ mm. Number of whorls unknown. Median lobe embraced by succeeding whorls, showing the side of the whorls in the narrow umbilicus. Periphery at mid of evenly convex whorl with slightly increased curvature of the umbilical wall towards the umbilici. Transition to median lobe weakly concave. Height of lobe approximately the same as height of the whorl. Width of median lobe $2 / 3$ of total width, but narrower adaperturally at the laterally expanding apertural part of the whorl. Median band flat, outlined by grooves on the median lobe, being slightly narrower than the lobe itself. Ornamentation, apertural lip and median anterior sinus unknown.

Remarks. With a length of nearly $10 \mathrm{~mm}$ Tritonophon grandis sp. nov. is the largest species of the genus hitherto known. It is also the youngest Ordovician occurrence of the taxon. The shell is about as wide as it is long, and the broad median lobe bears a slightly narrower median band. The shell therefore has a broadly rounded profile, compared to the narrow, pointed outline of the type species and other species of the genus. Two large specimens (MGM-6968X in Fig. 10f \& MGM-6971X) have slightly narrower whorl widths and the median lobe is more pronounced than compared to the holotype specimen. However, all five known specimens of the new species are preserved in a soft decalcified coquina which invariably yields different preservation of internal moulds. 
The cross section of T. peeli from Iran shown by Ebbestad et al. (2008) illustrates that the median lobe is quite wide but higher than the whorl height in this species. In T. grandis the width of the lobe is proportionally larger and the height is proportionally lower. Tritonophon kivitalonae from the Silurian Stonehouse Formation, Nova Scotia, Canada, has a proportionally low median lobe compared to the height of the whorl but it is proportionally narrower than that in $T$. grandis.

Peel (1974) showed that the median band of the Silurian to Devonian Plectonotus occupies only part of the width of the median dorsal elevation, whereas it covers the entire width in Tritronophon. Generally, the trilobation in Tritonophon is more marked than that in Plectonotus. It could be argued that the narrow median dorsal band in T. grandis should suggest a placement with Plectonotus, but the marked trilobation suggests otherwise. The opposite argument was used by Peel (1974) for the Silurian Plectonotus cherylae Peel, 1974 that has a narrow shell with a Tritonophon-like median dorsal band, but a low median lobe.

Subfamily Bucaniinae Ulrich \& Scofield, 1897 Genus Bucanopsina Horný, 1997a

Type species. By original designation of Horný (1997a, p. 7, text-figs 1-10), Bucanopsis calypso Perner, 1903, p. 157, text-fig. 110, from the Upper Ordovician (Katian Stage) Zahořany Formation at Praha-Libeň, Bohemia, Czech Republic.

$$
\text { Bucanopsina calypso (Perner, 1903) }
$$

Material. 13 specimens mentioned by Horný (1997e). Typical specimens are figured here as 
667

668

669

670

671

672

673

674

675

676

677

678

679

680

681

682

683

684

685

686

687

688

689

690

691

Fig. 11a-d.

Localities and horizon. Destombes localities 899, 1640, and 1778, central and eastern AntiAtlas, Morocco. Lower Ktaoua Formation, Sandbian to Katian stages.

Remarks. This explanate species is characterized by its small size, a well-bordered but low median dorsal band, short median anterior slit, and massive parietal deposits. Horný (1996, 1997a, f) discussed in detail the differences between Bucanopsina and the broadly comparable Grandostoma Horný, 1962. The latter has a median apertural sinus while Bucanopsina has a median apertural slit. Widely explanate gastropods are typically associated with shallow water soft substrates (Peel 1984 and references therein; Horný 1997e).

Bucanopsina calypso was first reported from the Zahořany Formation in Bohemia, and constitutes a genus that has hitherto only been found in Bohemia and Morocco. It co-occurs in Morocco with Bohemian species of Sinuitopsis, Tritonophon, and Nonorios, also from the Zahořany Formation, but all of these genera are found outside the peri-Gondwanan areas and have longer ranges.

.

Clade Neritomorpha
Superfamily Platyceratoidea Hall, 1879
Family Platyceratidae Hall, 1879

Remarks. Bouchet \& Rocroi (2005) discovered that the original reference to the family-name by Knight (1934) was wrong (seemingly by lapsus calami). In a footnote Knight referred to Hall (1859) using Platyceridae as a heading on plates 1 to 8 in volume 3 of the 'Palaeontology of New York'. However, Platyceridae is used in Hall (1879), on plates 1 to 8 in volume 5 of 
692

693

694

695

696

697

698

699

700

701

702

703

704

705

706

707

708

709

710

711

712

713

714

715

716

the 'Palaeontology of New York'. Platyceridae was corrected to Platyceratidae by Knight (1934).

Palaeozoic platyceratids have two types of protoconchs, a tightly coiled type found as far back as the Silurian and an open coiled hook-like protoconch found as far back as the Early Ordovician (Frýda 1999; Frýda \& Rohr 2004; Frýda et al. 2009 and references therein). Note that although identifiable in the fossil record, these protoconch morphologies are rarely associated with teleoconchs. These important findings led the authors to suggest that Palaeozoic platyceratids are diphyletic and two sub-clades within the Neritomorpha, to which platyceratids have been associated (e.g. Bandel 1992), were erected; the Cyrtoneritimorpha for members with a hook-like protoconch and the Cycloneritimorpha for members with the tightly coiled protoconch. Possible patellogastropod affinities of the platyceratids suggested by Sutton et al. (2006) were dismissed by Frýda et al. (2009) owing to the uncertain affinity of the putative platyceratid from the Herefordshire Silurian lagerstätte that was the foundation for this suggestion.

Type species. By original designation of Horný (1997d, p. 46); Turbonitella pater Barrande in Perner, 1903, pl. 51, figs 1-3; 1907, p. 288, from the Upper Ordovician (Katian Stage)

Zahořany Formation at Vráž, Bohemia, Czech Republic.

Nonorios pater (Barrande in Perner, 1903)

(Fig. 12a-d)

Material (Moroccan specimens only). Three specimens mentioned by Horný (1997e). 
Localities and horizon. Destombes localities 1266, 1270, and 1276, eastern Anti-Atlas,

Morocco. Lower Ktaoua Formation, Katian Stage.

Remarks. Nonorios was erected by Horný (1997d) for a number of Ordovician platyceratid species discussed by Perner (1903, 1907). Nonorios pater is known from the Letná, Vinice, and Zahořany formations in Bohemia, the Lower Ktaoua Formation in Morocco, and strata

724

725 contemporaneous with the Vinice Formation in Spain (undescribed) (Horný 1997d, 1997e, 1999b; Gutiérrez-Marco et al. 1999). Typically it co-occurs with Holopea? antiquata (now placed with Radvanospira) in what Horný (1997e, 1999b) referred to as the Nonorios

Community; except for Sinuitopsis sp. none of the other co-occurring taxa in Bohemia can be found in Morocco.

Nonorios is characterized by the rapidly expanding turbiniform shell, large rounded aperture, an inner lip having a groove or channel and an ornamentation of both spiral and commarginal components (Fig. 12).

Horný (1997e) noted that $N$. pater and Holopea? [=Radvanospira] antiquata had been recognized by Romão et al. (1995) in Portugal under different names, and anticipated these two could also be recognized in France and Sardinia (Horný 2002). With respect to the latter he may have had Craspedostoma sardoum Vinassa de Regny, 1927 from the Late Ordovician (Katian) Portixeddu Formation in mind. This is a small rotund, anomphalous species that has an overall similarity with Nonorios but could as well be compared to Radvanospira antiquata. Without ornamentation preserved these two species can be difficult to separate (Horný 1997e) and more material is required in order to assess the degree of variation in these two species. Ebbestad et al. (2008) recognized Nonorios kleistos in the Late Ordovician (Sandbian) Katkoyeh Formation of the Kerman Region of east-central Iran. This is a large and thick- 
shelled species that develops a massively thickened base and a closed umbilicus at maturity.

The ornamentation lacks the spiral component seen in N. pater. Two other species tentatively assigned to Nonorios are known, the Late Ordovician (Katian) Nonorios? carnicus Vinassa de Regny of the Italian Carnic Alps and Nonorios? transversum Ulrich in Ulrich \& Scofield, Late Ordovician (Katian) of USA (see Horný 1997d; Ebbestad et al. 2008).

Type species. Designated here, Naticopsis antiquata Barrande in Perner, 1903, pl. 54, figs 3133, non 34-37from the Upper Ordovician (Sandbian to Katian) Letná to Zahořany formations, Bohemia, Czech Republic.

Diagnosis. Shell turbiniform with 4-5 evenly expanding whorls, whorl profile elongated, higher than wide. Aperture auriform to semi-circular. Width of shell up to $40 \mathrm{~mm}$. Shell thick, umbilicus closed, ornamentation of fine, straight to slightly irregular and densely spaced prosocline and sharp lirae. Entire aperture weakly inclined (up to $\sim 35^{\circ}$ ), inner lip reflexed with channel, thicker than base and outer lip.

Derivation of name. Named in honour of the late Dr Radvan J. Horný, Czech Republic, for his outstanding contributions to the understanding of Lower Palaeozoic molluscs and their evolution. The names is combined with the Latin Spira, a spire. The ending is feminine.

Remarks. The type species of Radvanospira, H.? antiguata (Barrande in Perner) cannot be placed with Holopea Hall. Species of Holopea are generally smaller, have thinner shells, no thickening of the inner lip and no inner lip channel, the whorls are more rounded with deeper 
sutures, and the ornamentation generally consists of finer threads. The preservation of Radvanospira, although variable, suggests that the shell was primarily calcitic whereas that of Holopea spp. is seldom preserved, leaving mainly steinkerns, which is typical in taxa with an aragonitic shell (see Cherns et al. 2008).

Radvanospira resembles species of Platystoma Conrad and Naticonema Perner, but both of these genera have a more rapid shell expansion giving a lower, more rotund shell form (i.e. Naticiform) and have a more rounded whorl profile. Ornamentation in Platyostoma typically has a spiral component.

Radvanospira gen. nov. is an important genus in southern Gondwana, begin widely recognized through $R$. antiquata (see discussion for the species, and also discussion under Nonorios pater).

Perner $(1903,1907)$ described a number of Ordovician and Silurian species attributed to Holopea, and these need to be examined for comparison with Radvanospira. Likewise, species of Holopea s.l. in other collections of the southern Gondwanan areas should be carefully examined to seek for the presence of Radvanospira, but this is beyond the scope of this paper.

The close similarity of $R$. antiquata to the platyceratid $N$. pater was noted by Horný (1997e), and the morphological traits in Radvanospira discussed above also seem to warrant the placement of the genus in the family Platyceratidae.

Radvanospira antiquata (Perner, 1903)

(Figs $13 \mathrm{a}-\mathrm{g} \& 14 \mathrm{a}-\mathrm{h})$

*1903 Naticopsis antiquata Barrande in Perner, pl. 54, figs 31-33, non 34-37.

1907 Naticopsis antiquata Barrande in Perner. - Perner, p. 289. 
1911 Platyostoma ferrigenum Barrande in Perner. - Perner, p. 170.

?1975 Holopea sp. - Carls, p. 136.

?1995 Holopea? sp. - Romão et al., p. 124.

1997e Holopea? antiquata Barrande in Perner. - Horný p. 60, pl. 15, figs 1-13; pl. 16, figs 16.

?1997 Holopea? sp. - Gutiérrez-Marco et al., p. 35.

1999 Holopea? antiquata (Barrande in Perner). - Gutiérrez-Marco et al., p. 490.

1999 ? Holopea - Horný, p. 398.

2000 Holopea? antiquata (Barrande in Perner). - Horný, p. 421.

2003 Holopea? antiquata (Barrande). - Herranz Araújo et al., p. 422.

2006 Holopea? antiquata (Barrande). - Villas et al., p. 734.

2006 Holopea? antiquata (Barrande). - Sá, p. 618, fig. 1.

2008 Holopea? antiquata Barrande in Perner. - Sá, p. 56, fig. 2; pl. 5, figs 11-13.

?2016 Holopa sp. - Monteserín López et al., p. 19.

Lectotype. Designated by Horný (1997e, p. 60), specimen NM L8443 figured by Perner (1903, pl. 54, fig. 33).

Material (Moroccan material). 15 specimens mentioned by Horný (1997e) and five new specimens added herein (specimens MGM-6972X-MGM-6976X).

Localities and horizons. Destombes localities 88, 1250, 1266, 1302, 1305, 1313, and 1315, eastern Anti-Atlas, Morocco. Lower Ktaoua and Upper Tiouririne formations, Katian Stage. Erfoud 2, eastern Anti-Atlas, Morocco. Upper Tiouririne Formation (MGM specimens), Katian Stage. 
Remarks. The species was described by Horný (1997e) but some emendations and additions can be made, and some typical specimens are re-figured here (Figs $13 \& 14$ ). Originally it was stated that the species has three to four whorls, which would suggest very rapid whorl expansion. However, the available specimens show at least three whorls preserved with the spire being eroded (Figs 13d \& 14e). Thus the shell had at least four whorls and most likely five giving it a low turbiniform shape rather than naticiform. The whorl expansion rate $\mathrm{W}$ (see methods) is around 2 in the comparable $R$. baniensis sp. nov. although that species has a slightly higher rate of translation down the axis. The periphery is at mid-height of whorl. Inclination of entire aperture in $R$. antiquata is about $35^{\circ}$, and there is very little posterior projection of base. The inner margin of the aperture in large specimens is evenly curved but parallel to the axis of coiling (Fig. 13a). In a juvenile specimen attributed to the species the curvature of the inner margin is absent as it is inclined at about $15^{\circ}$ to the axis (Fig. $14 \mathrm{f} \& \mathrm{~g}$ ). The apertural edge is broken and may not show the inner margin entirely correctly, but an ontogenetic change in the curvature and inclination of this feature seems likely.

Besides Bohemia and Morocco, Holopea? antiquata has been reported from the Central Iberian Zone at Camada Favaçal (Buçaco), Amêndoa-Mação, and the Trás-os-Montes region (see Sá 2008). In Spain a number of occurrences may relate to R. antiquata or Radvanospira spp., which could be common in middle Berounian (Katian) strata. Holopea? has been mentioned in the eastern (or Aragonian) branch of the Iberian Ranges (Carls 1975), in the

837 Western (or Castilian) branch of the same (Herranz Araújo et al. 2003), and is abundant in other strata such as the Cantera Shales/base of the Bancos Mixtos Formation of the Viso del 839 Marqués syncline of the southern Central Iberian Zone (Monteserín López et al. 2016). In the West Asturian-Leonese Zone (NW Spain), Holopea? sp. occurs within an assemblage of brachiopods, trilobites, and bryozoans correlatable with those from the Iberian Ranges and the 
Central Iberian Zone of Spain and Portugal (Gutiérrez-Marco et al. 1997). Note that the 1987 reference in the synonym list of Sá (2008) is erroneous. All of these records need to be reassessed in the light of the Bohemian and Moroccan material.

Radvanospira baniensis sp. nov.

(Figs 15a-i \& 16)

Types. Holotype (MGM-6977X) and paratype (partial steinkern) (MGM-6978X) (Figs 15 \& 16).

Diagnosis. A species of Radvanospira with a shell of sub-equal width and height, an apical angle of $\sim 85^{\circ}$, inclination of aperture around $30^{\circ}$, width of aperture less than height, periphery slightly below mid-height of whorl. Ornamentation consisting of gently prosocline lira without undulations or bifurcations.

Derivation of name. After the Upper Bani Group in which this species occur.

Type locality and horizon. Ait Isioul 'south', West of Tagounite, central Anti-Atlas, Morocco. Lower Second Bani Formation, horizon T4, Hirnantian Stage.

Description. Shell $~ 20 \mathrm{~mm}$ wide with at least four whorls. Height slightly greater than width. Whorl profile auriform with evenly and gently convex upper and lower whorl surfaces, but with periphery slightly below mid-height of whorl. Whorl expansion rate is about 2 . Whorls overlap slightly below periphery with sharp suture line but without being incised. Apical angle is $\sim 85^{\circ}$. Earliest whorl(s) and protoconch unknown. Aperture tangential, simple, 
inclined about $\sim 30^{\circ}$. Outer lip entire, without a sinus, base rounded with an angle of about $60^{\circ}$ to inner margin. Shell thick with thickening of inner margin which is gently curved, nearly straight, broad, flat and slightly recurved, bearing a shallow groove along most of its length.

Ornamentation consists of fine, sharp lirae that are straight without undulations or bifurcations. In early ontogeny there are as many as $\sim 10 / \mathrm{mm}$ and $\sim 5 / \mathrm{mm}$ in later ontogeny.

Remarks. Radvanospira baniensis sp. nov. is smaller than $R$. antiquata, with a more pronounced auriform aperture that is slightly less inclined. The periphery of the whorls is a little lower and the translation down the axis is greater than in $R$. antiquata. In both species the ornamentation is equally dense and the lirae are sharp, but in $R$. baniensis they are straight without the undulations and bifurcation seen in $R$. antiquata.

\section{Superfamily Eotomarioidea Ulrich \& Scofield, 1897}

Family Gosseletinidae Wenz, 1938

Subfamily Euryzoninae Wagner, 2002

Type species. - By original designation of Wagner (2002, p. 85), Trochus ellipticus Hisinger, 1831, p. 11, pl. 2, fig. 2. From the Upper Ordovician (Sandbian) Dalby Limestone at Furudal in the Siljan District, Sweden.

Remarks. The type species of Deaechospira Wagner was discussed by Frisk \& Ebbestad (2007). The type material is poorly preserved, but well-preserved exemplars of the species are known from both Sweden and Norway (see also Yochelson 1963). This predominantly 
Baltoscandian genus differs from the North American Clathrospira Ulrich \& Sofield, 1897 in a more convex whorl profile, a peripheral band that is broader and symmetrical placed on the periphery, between the upper and lower whorl, rather than more on the upper whorl surface. The upper whorl of Clathrospira is higher (adapically) than the lower part, so that the band appears to sit low on the whorl. The bordering lirae of the band are less prominent in Deaechospira, and there is a greater symmetry between the upper and lower parts of the whorl than in Clathrospira.

Identifying this genus in southern Gondwana is not unreasonable. A number of gastropod and tergomyan taxa first identified in, and specific to, Bohemia have later been found in Baltica, such as Sarkanella Horný, Laeogyra Perner, Grandostoma Horný, and Carcassonnella Horný \& Peel (see Ebbestad 2008; Stewart 2012; Ebbestad et al. 2013b). There is an obvious similarity between the wider Mediterranean faunas (e.g. Gutiérrez-Marco et al. 2017), although of the mentioned taxa only Carcassonnella has hitherto be found in Baltica, Bohemia, and Morocco (Ebbestad 2016).

Holotype. Specimen NM S2564, re-illustrated here in Fig. 17a-h.

Deaechospira amouguerana (Horný, 1997e)

(Figs 17a-h, 18a-k \& 19a-e)

Material. 47 specimens mentioned by Horný (1997e).

Localities and horizons. Destombes localities 86, 88, 882, 1100, 1266, 1652, and 1778, eastern Anti-Atlas, Morocco (except locality1652 from the High Atlas north of Ouarzazate). Lower Ktaoua Formation, Katian Stage except for the Sandbian Stage localities 1100 and 
1778. Localities 585, 1134, and 1282, eastern Anti-Atlas, Morocco. Upper Tiouririne Formation, Katian Stage.

Remarks. The species was described by Horný (1997e), and previously illustrated and nonillustrated material is presented here (Figs 17-19). Additional observations on the morphology can be added here. Most likely the species has more than six whorls, as this is the number of observable preserved whorls and the spire is missing. The apertural sinus is welldeveloped and easy to follow, but does not seem to generate a slit. In specimen NM S2686, not illustrated by Horný (1997e), the course of the sinus and development of the peripheral band suggest development of a short sinus at the sinus apex (Fig. 18g-h); the sides of the sinus are not sub-paralell. A portion of the band in specimen NM S2685 (Fig. 18f) is lacking lirae and the apex sinus is clearly seen. On the internal mould of NM S2684 the impression of the peripheral band is raised medially and flanked by shallow spiral depressions (Fig. 18k). In the juvenile specimen (Fig. 19) the peripheral band is flush with the whorl and the bordering lirae are very faint. The band may even be positioned slightly higher on the whorl, as in Clathrospira, although the roundness and symmetry of the whorls in Deaechospira clearly set these genera apart.

Horný (1997e) compared the Moroccan species closely to Clathrospira egens (Barrande in Perner, 1907) from the Zahořany Formation in Bohemia. This appears to be a smaller species, with a more convex whorl profile, deeper sutures, stronger lirae bordering the peripheral band, and less prosocline growth lines giving a shallower apertural sinus. The Bohemian species is also transferred to Deaechospira.

D. amouguerana is similar to the type species D. elliptica (Hisinger) in its large size and high number of whorls. The base in the type species is flatter, the upper whorl profile is less 
convex, the lirae bordering the peripheral band are stronger, the lunulae of the band are asymmetrical, and the band has a spiral thread that is lacking in the Moroccan species.

\section{Deaechospira sp.}

(Fig. 20a-i)

Material. Four specimens mentioned by Horný (1997e), of which three have been studied here (NM S2687-NM S2689).

Locality and horizon. Destombes locality 134, eastern Anti-Atlas, Morocco. Upper Tiouririne Formation, Katian Stage.

Remarks. Horný (1997e) described the species in detail, but some additions can be made. The species has at least four whorls preserved, and most likely had five to six whorls. The peripheral band is broad, straight and slightly sunken between the upper and lower border so that bordering lirae are not really standing out from the shell but forming a ledge. Horný (1997e) recorded a faint angulation on the lower whorl surface of the internal mould of NM S 2689, but this cannot be substantiated (Fig. 20a, c \& d). A muscle impression is present on the base of the same specimen (Fig. 20d). It is crescent-shaped, with a well-defined outer edge, positioned on the umbilical wall and encroaching slightly onto the base of the whorl. It starts quarter of a whorl back from the aperture and extends nearly three quarters of a whorl back abaperturally where it disappears under the matrix. The surface is textured with fine irregular and wrinkled, discontinuous lines.

The position of the muscle impression close to the aperture and sinus suggest that the snail was not capable of deep withdrawal of the body. Instead the near-aperture position of the scar, 
the rounded and straight aperture would suggest clamping behaviour of this species (see discussion on clamping behaviour in Ebbestad \& Peel 2001 and references therein). Horný (1997e) placed these specimens with the true Lophospira Miller, which is not supported here. The general shell shape, great symmetry of the apertural sinus and its symmetrical placement on the periphery, the broad peripheral band with well-defined lirae, and the median spiral lira on the band support a placement with Deaechospira. Although the material seems well-enough preserved to define a species, a new name is not put forward. This is because one get the sense that Hórny (1997e) may have compared these specimens with contemporaneous Bohemian material and expected similarities. Most of the original Perner material has not been examined for this project, and a designation will have to await a thorough revision of that material.

Deaechospira sp. is smaller than D. amouguerana but both share a similar shell shape, a broad peripheral band and a symmetrical and short apertural sinus (for the latter character compare Fig. 18g-i with Fig. 20c \& e). The development of the peripheral band is different in the two, where the peripheral band of Deaechospira sp. has distinct upper and lower lirae and a lira placed low on the peripheral band, whereas in D. amouguerana the band is slightly raised with more indistinct bordering lirae and no lira on the band (compare Fig. $17 \mathrm{~g} \& \mathrm{~h}$ with Fig. 20f).

Type species. Designated here, Lophospira? debganensis Horný, 1997e, p. 58, pl. 13, figs 710, pl. 14, figs 1-9, from the Upper Ordovician (Katian) Upper Ktaoua Formation, central and eastern Anti-Atlas, Morocco. 
Diagnosis. (Modified from the diagnosis of Lophospira? debganensis by Horný 1997e). Shell trochiform but slightly coeloconical at maturity, upper whorl surface of earliest whorls weakly convex. Shell up to $35 \mathrm{~mm}$ wide, with at least six whorls, with increasing translation during ontogeny. Aperture with a deep, narrow asymmetrical sinus. Peripheral band vertical in early ontogeny with sharp upper edge, changing to a slightly inflated band with raised weakly defined median keel at apex of asymmetrical lunulae. At maturity band extend out from shell, curving slightly adapically.

Derivation of name. From Greek Allosso, meaning change, changeable, referring to the marked ontogenetic changes in the shell of this taxon. The name is combined with the Latin Spira, a spire. The ending is feminine.

Remarks. The original placement of this genus with the Lophospirids is not upheld, and by comparison with Deaechospira it is being placed in the subfamily Euryzoninae Wagner.

Horný (1997e) discussed a number of species attributed to Pleurotomaria (Lophospira) s.l. by Perner (1903, 1907), and while some of these (especially L. infausta Perner) may be close to Allossospira they have not been studied in the present work.

\section{Allossospira debganensis (Horný, 1997e)}

(Figs 21a-i, 22a-h, 23a-c \& 24a, b)

Holotype. Specimen NM S2466, figured here as Fig. 21a-i.

Diagnosis. Same as for genus. 
Material. 37 specimens reported by Horný (1997e) and 16 new specimens added here (MGM6979X-MGM-6991X; the number MGM-6985X includes three specimens and number MGM-6991X includes two specimens).

Localities and horizon. Destombes localities 49, 757, 901, 1077, 1078, 1109, 1125, 1132 (holotype), 1146, 1649 (marked as 1149 in Horný 1997e), 1791, and Jbel Bou Ingarf 'south' (MGM specimens listed under material), central and eastern Anti-Atlas, Morocco. Upper Ktaoua Formation, Katian Stage.

Description (modified and emended from Horný 1997e). Shell trochiform, anomphalous, with at least six whorls. Spire angle of $\sim 80^{\circ}$, whorl expansion rate $\sim 1.7$. Whorls embraced just below periphery, obscuring the lower part of the peripheral sinus, but rate of translation increases during ontogeny so that lower part of peripheral sinus becomes visible. Suture is shallow. Upper whorl surface on initial three to four whorls nearly straight or slightly convex, bulging slightly at upper margin of peripheral sinus, becoming gradually weakly concave and finally strongly concave at maturity, giving a coeloconical appearance. Peripheral band vertical in early ontogeny, slightly concave with sharp upper edge, changing to a slightly inflated band with raised, weakly defined median keel from fourth whorl onwards and with gradually increased convexity. At maturity peripheral band carina-like, extending out from shell, rounded and curving slightly adapically. Growth lines consist of fine, dense, slightly irregular prosocline lines above periphery, but curving slightly anteriorly close to suture before turning backwards with increased curvature near periphery. Below periphery growth lines run anteriorly and slightly abapically, at the upper third of the whorl, thereafter turning in a wide convex arch back towards the umbilicus. Base projecting anteriorly in umbilical view. Aperture inclined about $15^{\circ}$, with lower side being more inclined than upper side. 
Apertural sinus forms wide and deep V-shape, asymmetrical with lower side being wider. Apex of sinus coincides with spiral keel. Upper part of sinus and lunulae sub-parallel owing to the increased curvature of the growth lines at the periphery, defining the sharp edge in early ontogeny. Lunulae open below periphery. Upper edge of lunulae lost during ontogeny as peripheral band becomes convex and protruding from shell. Protoconch not preserved, but possibly simple and bulbous.

Remarks. Allossospira gen. nov. is a taxon that displays a number of major ontogenetic changes; the convexity of the upper whorl surfaces goes from slightly convex to strongly concave and almost perpendicular to the axis of coiling, the peripheral band goes from flat with a sharp upper edge to bulging and upturned with a weak median carina so that the growth lines continue uninterruptedly across the periphery, and the rate of translation increases during ontogeny. The aperture is slightly inclined with greater inclination of the lower half, reflecting the asymmetric and deep V-shaped sinus and the anterior projection of the base. Although the initial part of the spire and the protoconch is missing, specimen MGM-6982X (arrow in Fig. 22f) preserves an external impression of what may be the protoconch. The structure is about $250 \mu \mathrm{m}$ across, and would be simple, openly coiled.

The concave upper whorl surface and upturned peripheral band at maturity is reminiscent of similar features in some raphistomiid species of Raphistoma Hall and Scalites Emmons, and the eotomariid Phanerotrema Fischer, but in these forms these characters are continuous. Most of these taxa has spiral ornamentation and Raphistoma and Scalites generally has a basal carina which is absent in the anomphalous Allossospira.

It is clear that there are no peripheral lirae in Allossospira. The sharp upper line in early ontogeny is purely a result of the growth lines sweeping strongly backwards and aligning 
1065

1066

1067

1068

1069

1070

1071

1072

1073

1074

1075

1076

1077

1078

1079

1080

1081

1082

1083

1084

1085

1086

1087

1088

1089

(Fig. 21g). As the periphery starts to bulge the growth lines are pulled out and the tight congregation seen at the flat band is lost (arrows in Fig. 21e).

Originally the genus was tentatively placed with Lophospira Whitfield. The lophospiroids, including the lophospirids and the trochonematids, are a species rich group that was revised by Wagner $(1995,1999)$. The group as a whole contain species with both comarginal and spiral ornamentation, many exhibiting a carina on the lower whorl surface, a basal carina, a phaneromphalus umbilicus, and deep sutures. Typically, the peripheral band is bordered by lirae and it contains one or more spiral components or a keel. Most of these characters are not seen in Allossospira, although the anterior projection of the base is shared with many lophospirids. The peripheral band keel in Allossospira is an indistinct feature and develops late in the ontogeny, and is somewhat reminiscent of the structure seen in Lophospira milleri (Miller), the type species of Lophospira. Both Knight (1941) and Horný (1997e) used the term pseudo-selenizone to describe the nature of the peripheral band in L. milleri and L.? debganensis respectively. A broadly similar situation is seen in the eotomarid genus Semizona Ebbestad \& Peel, 2001 from the Late Ordovician of Sweden, where the curvature of growth lines of the upper whorl surface are almost horizontal at the periphery and creats the impression of a border on the upper part of the peripheral band; Semizona lacks a peripheral keel (Ebbestad \& Peel 2001). It is considered important that these characters together with the convex upper whorl surface and protruding peripheral band, are a gerontic development in Allossospira. Together with the other characters discussed above, this separates the genus from the lophospirids.

Three juvenile specimens of Allossospira debganensis, all on the same block of matrix, appear very similar to the juvenile Deaechospira amouguerana (compare Figs $19 \& 23$ ). Growth lines of the upper whorl surface of Allossospira debganensis curve more strongly abaperturally, and while the peripheral band is not bordered by lirae, it is horizontal with a 
sharp and distinct edge on the upper whorl surface. Allossospira is also similar to Deaechospira ellpitica, the type specis of the latter genus, in the asymmetrical development of the apertural sinus. While $D$. elliptica has a bordered peripheral band, the lunulae are asymmetrical, with the lower half being the widest. In D. elliptica the peripheral band has a spiral lira, which is absent in Allossospira. Although both are quite large, the two differ in the convexity of the upper whorl surface of the last whorl, but have a similar inclination of the aperture owing to the asymmetrical apertural sinus. In Deaechospira the sinus is not very deep, and as seen in D. amouguerana the sinus dos not generate a proper slit. The latter species has a peripheral band bordered by lirae, lacking in Allossospira.

\section{Superfamily Lophospiroidea Wenz, 1938}

Family Lophospiridae Wenz, 1938

Genus Lophospira Whitfield, 1886

Type species. By subsequent designation of Oehlert (1888, p. 23), Murchisonia bicincta Hall, 1847, now considered a junior synonym of Murchisonia milleri Miller, 1877. Upper

Ordovician (Katian Stage) Trenton Limestone at Waterstown, New York State, USA.

Holotype. Specimen MGM-6992X, figured here as Fig. 25a-d, f-h, i \& k.

Lophospira latilabra sp. nov.

(Fig. 25a-k)

Paratypes. Two specimen MGM-6993X-1 and MGM-6993X-2 (not figured), from the same locality as the holotype (Fig. 25e \& j). 
Diagnosis. A species of Lophospira with seven non-disjunct whorls, a sharp wedge-shaped and from the fourth whorl - continuous peripheral band, deep shovel-like base and inner margin.

Derivation of name. From Latin Lata, Wide and Labrum, giving the meaning wide-lipped, pertaining to the large prominent inner margin and base in this species.

Type locality and horizon. Jbel Bou Ingarf ‘south’, central Anti-Atlas, Morocco. Upper Ktaoua Formation, Katian Stage.

Description. Shell moderately high spired, with seven whorls. Height of holotype $12 \mathrm{~mm}$, width $7 \mathrm{~mm}$. Spire angle is $60^{\circ}$. Umbilicus anomphalus, the base curving sharply toward the umbilicus. Upper whorl surface steeply inclined ( $30^{\circ}$ relative to axis of coiling), evenly concave with a sharp upper angulation (sutural shelf) that is nearly horizontal and at the height of the suture. Suture simple, not incised. Thin peripheral band placed symmetrical on periphery, slightly sunken and bordered by fine, thin ledge-like edges that are not raised as lirae but flush with upper and lower whorl surfaces. Band bluntly wedge-shaped without visible lunulae. Band is first manifested on the fourth whorl. Apertural sinus broad, V-shaped and short. Inclination of aperture slight, nearly vertical. Base nearly straight, abapertural projection gentle. Upper part of lower whorl surface nearly vertical and weakly concave above low, blunt spiral carina, and gently convex below carina with an angle of about $50^{\circ}$ relative to axis of coiling. Upper surface and lower surface down to carina symmetrical in shape. Whorls embrace at carina, obscuring this in earlier whorls. Aperture of similar height and width (sub-rounded in outline). Outer margin thin above periphery, gradually widening 
into wide and broad shovel-like base and inner margin. Angle between base and inner margin about $15^{\circ}$. Inner margin straight, gently curved with faint longitudinal groove, reflected around axis of coiling. Apex of sinus nearly perpendicular relative to axis of coiling (angles about $80^{\circ}$ adapically). Protoconch not preserved in detail, but seemingly simple, open coiled. Ornamentation consists of fine gently prosocline growth lines on upper whorl surface. Below the peripheral band the growth lines are of same strength as above, curving gently convex to carina before turning sharply abaperturally towards umbilicus.

Remarks. The holotype is an external mould preserved in two halves of a nodule. Silicone casts were made for each half, completing the specimen (Fig. 25a-d, k shows one half and $25 \mathrm{f}-\mathrm{i}$ the other half). The paratypes are preserved with the impression of one side only, allowing a silicon cast to be made.

This species is similar to North American Ordovician species of angular Lophospira (major differences given in parentheses behind each species); for instance L. perangulata (Hall) (taller, steeper spire angle, lower carina not embraced by subsequent whorls), $L$. sorocula (Billings) (fewer whorls?, less prominent sutural shelf, more prominent carina on lower surface, stronger ornamentation, more incised suture at maturity), and Lophospira milleri Miller (less distinct and sloping sutural shelf, less distinct peripheral band lacking the sharp wedge-shape, coarser ornamentation). The Moroccan species resembles even some species of Paupospira Wagner, recognized by its thick columnella and the shovel-like aperture, but the nature of the columella is unknown in L. latilabra and the trilineation of the peripheral band is continuous.

Some similar taxa from other Ordovician deposits are (in alphabetical order): L. acuta Grabau (Korea, North China: more narrow and taller, more curved inner margin, whorls embrace below carina on lower whorl surface), L. argenta Tassel (Australia: narrower and 

taller, lacking sutural shelf, whorls embrace below carina on lower whorl surface), L. jaekeli (Koken in Koken \& Perner) (drift material in Germany, originating from Scandinavia. Too little is known of this species to compare),

Lophospira is a wide-spread taxon in the Ordovician, mostly in the warm water realms, but also unequivocally present in cold-water southern Gondwana. The specimen from Morocco attributed to Lophospira by Horný (1997e) is here placed differently, while the affinity of $L$. latilabra is more certain. Several Bohemian taxa need to be considered to be able to understand the distribution of this genus, but that is beyond the scope of this study.

Remarks. A poorly featureless external mould of a high-spired gastropod with ten whorls was tentatively attributed to Loxonema? sp. by Horný (1997e, pl. 16, figs 14 \& 15). The poor state of the specimen (latex cast) does not allow identification of its affinity and it is here treated as indeterminable. The specimen comes from Destombes locality 1791, Upper Ktaoua Formation (Katian), eastern Anti-Atlas, Morocco.

Class Bivalvia Linné, 1758

Subclass Protobranchia Pelseneer, 1889

Superorder Nuculiformii Gray, 1824

Order Nuculoida Dall, 1889

Superfamily Nuculoidea Gray, 1824

Family Praenuculidae McAlester, 1969

Genus Praenucula Pfab, 1934 
Type species. By subsequent designation of Pfab (1934, p. 235), Nucula dispar Barrande, 1881d, pl. 273, from the Mid Ordovician (early and mid Darriwilian Stage) Šárka Formation at Osek, Bohemia, Czech Republic.

Remarks. The similarity between the genera Praenucula, Praeleda, and Deceptrix were previously discussed in many papers (Bradshaw 1970; Pojeta 1978; Tunnicliff 1982; Babin \& Gutiérrez-Marco 1991; Cope 1997, 1999; Babin \& Beaulieu 2003; Kř́ž \& Steinová 2009; Polechová 2013). Here only the main opinions regarding these genera are discussed, as this is otherwise beyond the scope of the paper. According to Cope (1997), the genus Deceptrix is valid, but it is characteristic of the Devonian while Praeleda and Praenucula are characteristic of the Ordovician. Tunnicliff (1982) suggested the following main differences between Praenucula and Praeleda (in his concept Deceptrix): 1) the posterior teeth in Praeleda (='Deceptrix') are smaller and more numerous than the anterior teeth while in Praenucula the posterior and anterior teeth are similar in size and number; 2) umbos in Praenucula lie in the posterior half while in 'Deceptrix' they generally lie in the anterior half; 3) in 'Deceptrix' the adductor muscle scars are larger and in a more ventral position, in Praenucula they are close to the dorsal margin. Cope (1999) added another character: between the anterior and posterior hinge range it is possible (but not always) to find the discordance). In conclusion, all these authors noted the similarity between these two genera and they could be congeneric. In the Late Ordovician of Bohemia these two genera are very common and their species show a mixture of the characters, which should be characteristic only for one genus. On the other hand, there are species which correspond perfectly only with the diagnose of Praenucula or Praeleda (e.g. Praenucula dispar, Praeleda pulchra). Moroccan specimens of Praenucula show a mixture of these characters: posterior teeth are 
smaller and more numerous, the anterior adductor is more ventral (characteristic for Praeleda); the hinge ranges do not show any discordance or disruption, and umbos lie in the posterior half (characteristic of Praenucula).

\section{Praenucula pojetai sp. nov.}

(Fig. 26b, c \& k-q)

1990 Praenucula costae Sharpe. - Babin \& Destombes, pl. 1, fig. 6.

Holotype. Internal mould of the left valve, MGM-6845X, figured herein as Fig. 26o, p \& q.

Paratypes. Five right valves, two left valves, one articulated specimen (specimens FSL 550113, FSL 550118, FSL 550161, MGM-6843X, MGM-6844X, MGM-6846X, MGM6848X, MGM-6849X). Measurements are given in Table 2. MGM-6846X is figured herein as Fig. $26 b \& \mathrm{~m}$.

Diagnosis. Praenucula with broadly subelliptic to ovate shells, with nine to 11 teeth in the anterior part of the hinge and with 15-20 smaller teeth in the posterior part of the hinge. Three pairs of accessory muscle scars constitute row in the umbonal region, toward to the anterior part of the shell they are smaller.

Derivation of name. In honour of John Pojeta, Jr. (1935-2017), who devoted his research mainly to Palaeozoic bivalves and rostroconchs. 
Type locality and horizons. North slope of the Jbel Amouguer, south of the eastern Sarhro Massif, Jbel Bou Isidane, south of Alnif, eastern Anti-Atlas, Morocco. Lower Ktaoua Formation, Sandbian Stage. Jbel Bou Ingarf 'south' (holotype) and Jbel Bou Ingarf 'north', central Anti-Atlas, Morocco. Upper Ktaoua Formation, Katian Stage. Near the Tizi n’Takrit, 7 km southwest of Tazarine (Maïder), eastern Anti-Atlas, Morocco. Lower Member of the Lower Second Bani Formation, upper Katian Stage.

Description. Small, equivalve, inequilateral, and broadly subelliptic to ovate shell. Anterior margin evenly rounded, posterior margin more straight, ventral margin convex. Anterior part constitutes larger part of the shell. Umbos are situated in the posterior half of the shell length. Dorsal margin in the anterior part of the shell is slightly concave. Posterior part of the shell is slightly convex or straight. The hinge is taxodont, the posterior part with small numerous teeth (15-20 in number), and the anterior part of the shell with abruptly larger teeth (9-11 in number). Teeth in the posterior part are slightly convexodont or orthomorphodont, in the anterior part convexodont. Teeth row between the umbos is not interrupted. Anterior adductor muscle scar elliptic and slightly larger than elliptic posterior adductor muscle scar. One pair of elliptic pedal muscle scars (protractors) is developed posterodorsally from the anterior adductor muscle scars, one pair of slightly elliptic pedal muscle scars (retractors) is developed anterodorsally from the posterior adductor muscle scar, and three pairs of rounded accessory muscle scars are developed in the umbonal region. The accessory muscle scars toward the anterior part of the shell are smaller, the largest one is the closest to the umbo. Inner surface sculpture is smooth. Outer surface sculpture consists of numerous, regularly spaced growth bands and furrows.

Remarks. Praenucula dispar (Barrande, 1881d) from the Hirnantian of Bohemia differs from Praenucula pojetai in more rounded shape, prominent umbos and less numerous teeth, which 
show almost similar size. Praenucula abrupta Kř́̌ž \& Polechová, 2009 from the Hirnantian of Bohemia has triangular shape and prominent umbos and less numerous teeth. Praenucula dispersa Tunnicliff, 1982 from the Katian of Ireland has a more dorsally placed adductor muscle scars and teeth of almost similar size. Praenucula infirma Tunnicliff, 1982 from the Katian of Ireland, is distinguished from Praenucula pojetai on its more dorsally placed adductor muscle scars and prominent umbos. Praenucula praetermissa Tunnicliff, 1982 from the Katian of Ireland are characterised in more centrally placed umbos and more numerous teeth than Praenucula pojetai sp. nov. Praenucula sp. from the Sandbian of Argentina (Sánchez 1999) differs in having umbos in a central position and less numerous teeth in the posterior and anterior hinge lines. Ctenodonta dubia Hall, 1847 from the mid Katian (probably Katian 2) of Norway is similar to P. pojetai sp. nov. in shape, but other characters are unknown.

Family Nuculitidae Bradshaw, 1999

Genus Nuculites Conrad, 1841

Type species. By original designation, Nuculites oblongatus Conrad, 1841, p. 49, from the Mid Devonian Hamilton Group near Smyrna, Chenango County, New York, USA.

Nuculites sp.

(Fig. 27d, $\mathrm{m} \&$ o)

Material. One articulated specimen, one left valve (specimens MGM-6860X, MGM-6862X). Measurements are given in Table 3. 
1291

1292

1293

1294

1295

1296

1297

1298

1299

1300

1301

1302

1303

1304

1305

1306

1307

1308

1309

1310

1311

1312

1313

Description. Shell of very large size, equivalved, inequilateral, ovate or longitudinally elongated. Umbos inconspicuous, in the anterior part of shell, prosogyrate. Anterior margin rather straight, posterior margin rounded. Dorsal margin very slightly convex and ventral margin rather straight. The septum in the anterior part is relatively long and extends from anterior part of the hinge line towards the ventral margin of the shell, constituting an arc around the anterior adductor muscle scar. Posterior hinge line straight, the anterior hinge line curved ventrally. Hinge unknown, hinge line is preserved but seems to be without teeth, edentulous. The anterior adductor muscle scar badly preserved, occupying much of the portion of the shell anteriorly to the septum. Posterior adductor muscle scar unknown, outer surface sculpture with growth wrinkles.

Remarks. The genus Nuculites show very high variability of the shell, as it was demonstrated by Bretsky \& Bretsky (1977) for Nuculites planulatus and by Tunnicliff (1982) for Nuculites cylindricus. Nuculites sp. from the Late Ordovician of Morocco shows a key character for this genus, the septum. It is very characteristic in its dimensions, being a very large shell.

Locality and horizon. Mountain Pass south of Tagounite, central Anti-Atlas, Morocco. Lower Second Bani Formation, Hirnantian Stage.

Superfamily Nuculanoidea Adams \& Adams, 1858

Family Malletidae Adams \& Adams, 1858

Genus Myoplusia Neumayr, 1884 
Type species. By subsequent designation of McAlester (1968), Leda bilunata Barrande, 1881a, d, p. 153, pl. 270, fig. 3 from the Upper Ordovician (Katian Stage) Zahořany Formation at Štěrboholy, Bohemia, Czech Republic.

\section{Myoplusia sp.}

(Fig. 26a, d, e, g \& j)

Material. Two right valves, three left valves (specimens FSL 550117, MGM-6850X- MGM6853X). Measurements are given in Table 4.

Description. Shell small, equivalve, inequilateral, ovate, and longitudinally elongated. Umbos are placed at two thirds of the shell length, prosogyrate. Anterior part of the shell is smaller than posterior part of the shell. Anterior part and posterior part rounded, posterior part slightly truncate. Dorsal margin straight, ventral margin convex. Hinge preserved only in the anterior part, with numerous taxodont teeth (MGM-6852X). Anterior adductor muscle scar slightly ovate, posterior adductor muscle scar unknown. Inner surface sculpture smooth, outer surface sculpture unknown.

Remarks. Specimens from the Late Ordovician of Morocco are poorly preserved, so only the shape of the shell, prosogyrate umbos and taxodont teeth permit the determination to Myoplusia. The specimen MGM-6853X from the central Anti-Atlas differs from other Myoplusia in shape of the shell and very probably it represents a new species. It is very similar to Myoplusia incisa (Barrande, 1881d) from the Late Ordovician of Bohemia. 
Localities and horizons. Slope of the Jbel Amouguer, south of the eastern Sarhro Massif, eastern Anti-Atlas, Morocco. Lower Ktaoua Formation, Sandbian Stage. Jbel Bou Ingarf ‘south', central Anti-Atlas, Morocco. Upper Ktaoua Formation, Katian Stage. Aït Isioul 'north', central Anti-Atlas, Morocco. Lower Second Bani Formation, Hirnantian Stage.

Type species. By original designation, Sluha expansus Barrande, 1881a, p. 159, pl. 267 from the Upper Ordovician (upper Katian Stage) Králův Dvůr Formation at Lejškov Hill, Bohemia, Czech Republic.

Genus Sluha Barrande, 1881a

Sluha kosoviensis (Barrande, 1881d)

(Fig. 26f, h \& i)

*1881d Arca? kosoviensis Barrande, pl. 265, figs III/1-12.

1881d Arca? disputabilis Barrande, pl. 265, figs I/13-15.

1881d Arca? innotata Barrande, pl. 265, figs II/1-20.

1891 Praearca kosoviensis (Barrande). - Neumayr, p. 755.

1934 Praearca kosoviensis (Barrande). - Pfab, p. 220, pl. 3, fig. 21.

1934 Ctenodonta praecox (Barrande). - Pfab, p. 228, pl. 2, fig. 14.

1934 Ctenodonta disputabilis (Barrande).- Pfab, p. 228, pl. 2, fig. 15.

1934 Ctenodonta (Palaeoneilo) flectens (Barrande). - Pfab, p. 230, pl. 2, fig. 18.

1934 Ctenodonta (Palaeoneilo) magna (Barrande). - Pfab, p. 231, pl. 2, fig. 19.

1968 Praearca kosoviensis (Barrande). - McAlester, pp. 44, 45, pl. 30, figs 1-8.

1969 Sluha kosoviensis (Barrande). - McAlester, p. N235. 
2009 Sluha kosoviensis (Barrande). - Kříž \& Steinová, p. 420, pl. 3, fig. L-M \& pl. 5, fig. AC, E-L.

Material. Two left valves (specimens FSL 550162, MGM-6847X). Measurements are given in Table 5.

Types. Lectotype, designated by Pfab (1934), internal mould of a right valve figured by Barrande (1881d, pl. 265, figs III/9 \& 10), NM L 27070. Paralectotypes, internal mould of the shell with articulated and opened valves figured by Barrande (1881d, pl. 265, fig. III/1), NM L27072; internal mould of the shell with articulated and opened valves figured by Barrande (1881d, pl. 265, fig. III/2), NML27071; internal mould of the left valve figured by Barrande (1881d, pl. 265, figs III/3-5), NML27073; internal mould of the right valve figured by Barrande (1881d, pl. 265, figs III/6-8), NM L27069; internal mould of a left valve figured by Barrande (1881d, pl. 265, figs III/11 \& 12), NM L27068.

Type locality. Kosov Hill near Beroun, Bohemia, Czech Republic.

Type horizon. Late Ordovician, late Katian Stage, uppermost Králův Dvůr Formation.

Diagnosis. Sluha without prominent umbo, small orthomorphodont teeth in the anterior and posterior part of the shell and with the anterior smaller than the posterior portion of the shell.

Description. Shell medium size, equivalved, inequilateral, broadly ovate. Anterior part of the shell is smaller than posterior part. Anterior margin evenly rounded, posterior margin rather straight, ventral slightly convex, and dorsal margin convex. Umbos not prominent, in anterior 
half of the shell. Ligament external. Hinge line in anterior part of the shell slightly curved ventrally, in posterior part slightly convex. Taxodont teeth orthomorphodont. In anterior range of the hinge probably 6-7 teeth, in posterior hinge line probably $18-20$ teeth. Posterior adductor muscle scar large and rounded, close to the hinge line and posterior margin. Anterior adductor muscle scar smaller, also rounded, distant from the anterior hinge line. Inner surface smooth. Outer surface sculpture of fine growth wrinkles.

Remarks. Sluha kosoviensis is well known from the Late Ordovician of Bohemia (Barrande 1881a; Krríž \& Steinová 2009) and it is probably a direct descendant of Sluha expansus Barrande, 1881a, from the mid Katian of Bohemia. Moroccan specimens of Sluha are very similar to the Bohemian species, differing slightly in the more rounded shape of the shell.

Localities and horizons. Morocco: Jbel Bou Ingarf 'south', central Anti-Atlas. Upper part of the Upper Ktaoua Formation, Katian Stage. Near the Tizi n’Takrit, 7 km southwest of Tazarine (Maïder), eastern Anti-Atlas. Lower Member of the Lower Second Bani Formation, upper Katian. Bohemia, Czech Republic: Králův Dvůr Formation, Katian Stage.

Superfamily Nuculanoidea Adams \& Adams, 1858 Family Nuculanidae Adams \& Adams, 1858 Genus Phestia Chernyshev, 1951

Type species. By original designation of Chernyshev (1951), p. 9, Leda inflatiformis Chernyshev, 1939, p. 116, from the Carboniferous Formation $\mathrm{C}_{2}$ at Volchya River, Don Basin, Ukraine. 
Remarks. McAlester (in Cox et al. 1969) suggested that the widely used name Nuculana (Leda in older bibliography) should be restricted to Triassic-Recent forms with a rostrum and commarginal sculpture. Phestia should be used for stratigraphically older forms.

\section{Phestia? sp.}

(Fig. 30c)

Material. One right valve (specimen FSL 550115). Measurements are given in Table 6.

Description. The single right valve of an internal mould. Small, longitudinally elongated, equivalve, inequilateral. Umbos in the middle of the shell, rather orthogyrate. Anterior margin rounded, dorsal margin in the posterior part slightly concave, ventral margin convex. Posterior part of the shell extends into rostrum. Dentition and muscle scars unknown, and sculpture of inner surface smooth.

Remarks. Phestia? sp. from the Mid Ordovician of China is preserved as an external mould, so any comparison is difficult. Phestia rostellata (Hall, 1883) and Phestia diversa (Conrad, 1841) are stratigraphically younger (Devonian) than the taxon described here.

Locality and horizon. Plain between Jbel Tafenna and Ikhf n'Ouzerg, $60 \mathrm{~km}$ south east of Zagora, eastern Anti-Atlas, Morocco. Lower Ktaoua Formation, Sandbian Stage.

Subclass Autobranchia Grobben, 1894 Infraclass Pteriomorphia Beurlen, 1944 Cohort Mytilomorphi Férussac, 1822 (in Férussac \& Audebard 1822) 
Order Mytilida Férussac, 1822 (in Férussac \& Audebard 1822)

Superfamily Modiolopsoidea Fischer, 1886

Family Modiolopsidae Fischer, 1886

Genus Modiolopsis Hall, 1847

Type species. By original designation of Hall, 1847, p. 157, Pterinea modiolarisConrad, 1838, p. 118, from the Upper Ordovician (Katian Stage) Pulaski Formation, New York State, USA.

\section{Modiolopsis sp.}

(Fig. 30a, d \& e-k)

Material. Seven left valves, three right valves (specimens MGM-6854X, MGM-6855X,

MGM-6857X, MGM-6865X, MGM-6867X, MGM-6870X- MGM-6874X. Measurements are given in Table 7.

Description. Large shells, posteriorly elongated, modioliform, equivalve, inequilateral. Anterior part smaller, slightly lobate, evenly rounded, posterior part larger and rounded. Ventral margin convex, dorsal margin prominently convex. Umbos inconspicuous, situated very slightly above the hinge line, prosogyrate. Ligament opisthodetic. Outer surface sculpture composed of irregularly spaced growth wrinkles. Hinge plate edentulous, muscle scars and pallial line unknown.

\section{Remarks. Pojeta (1971) reported that more than 163 species belong to Modiolopsis. Very} often taxa have been determined only on the basis of the modioloform shape, edentulous hinge and growth ornamentation, so the determination to the species level may be very 
difficult. It is preferred to leave the Moroccan Modiolopsis in open nomenclature, because the whole concept of Modiolopsis requires revision.

Localities and horizon. Aït Isioul 'north' and ‘south', central Anti-Atlas, Morocco. Lower Second Bani Formation, Hirnantian Stage.

Genus Dceruska Barrande, 1881a

Type species. By original designation, Dceruska primula Barrande, 1881a, d, p. 77, pl. 275, fig. 2, from the Upper Ordovician (middle and upper Katian Stage) Králův Dvůr Formation at Lejškov Hill, Barrandian Area, Czech Republic.

Remarks. Some species of Modiolopsis are similar to Dceruska. The significant character of Dceruska noted by Kř́žž (2005) is the anterior lobe. Other significant characters may include the posteroventrally elongation of the shell and a prominently higher posterior part.

\section{Dceruska sp.}

(Fig. 27a, e \& h)

\section{Material. One articulated specimen, one left valve (MGM-6842X, MGM-6861X).}

Measurements are given in Table 8.

Description. Shell medium size, equivalved, inequilateral, modioliform, expanding posteroventrally, posterior part is prominently higher. Anterior part of the shell is smaller than posterior part. Anterior and posterior margins are evenly rounded, ventral margin convex, and 
dorsal margin straight. Umbos not prominent, in anterior half of the shell, not terminal, prosogyrate. Hinge edentulous. Opisthodetic ligament. Anterior adductor muscle scar small, evenly rounded, closed to the anterior margin. Inner surface with prominent growth bands in the ventral part. Outer surface sculpture unknown.

Remarks. Dceruska was described from the Late Ordovician of Bohemia by Barrande (1881a) and from the Telychian (Silurian) of Spain (Kř́ž 2005). Dceruska primula from the Katian of Bohemia has a prominent anterior lobe. Dceruska hispanica from the Telychian of Spain has a generally shorter shell and its shape is more pteriiform.

Locality and horizon. Aït Isioul ‘south’, central Anti-Atlas, Morocco. Lower Second Bani Formation, Hirnantian Stage.

Cohort Ostreomorphi Férussac, 1822 Order Myalinida Paul, 1939 Superfamily Ambonychioidea Miller, 1877 Family Ambonychiidae Miller, 1877 Genus Ambonychia Hall, 1847

Type species. By original designation, Ambonychia radiata Hall, 1847, p. 163, from the Upper Ordovician (Katian Stage) Lorraine Formation of USA.

\author{
Ambonychia aff. magna Isberg, 1934
}

(Fig. 29i) 
Material. One left valve (specimen MGM-6858X). Measurements are given in Table 9.

Description. - Shell large, inflated, equivalved, strongly inequilateral, longitudinally elongated. Umbos prominent, in the anterior part of shell, prosogyrate, rising above the hinge line. Posterior margin rounded. Ventral margin straight, curving rapidly up to the anterior margin. Angle alpha about $40^{\circ}$, angle gamma about $100^{\circ}$, angle beta about $150^{\circ}$ (see Fig. 28). Hinge line straight, dentition unknown. Muscle scars unknown. Inner surface sculpture is smooth. Outer surface sculptureof coarse rugae.

Remarks. Ambonychiids are a well known group of the Late Ordovician bivalves mainly because of the systematic work of Pojeta (1966). They were widespread; many species have been described from North America, Baltica, Avalonia, Australia, and China. They are typical representatives of epibyssate bivalves of this age. Ambonychia magna originally described from the Late Ordovician of Sweden is preserved as an external mould, while the present Moroccan species interpreted as Ambonychia aff. magna is preserved as an internal mould. In spite of the different aspects of preservation they seem to be very similar in shape and dimensions.

Locality and horizon. Aït Isioul ‘south', central Anti-Atlas, Morocco. Lower Second Bani Formation, Hirnantian Stage.

Ambonychia sp.

(Fig. 29b \& j)

Material. One articulated specimen (MGM-6866X). Measurements are given in Table 10. 
Description. Shell small, equivalved, strongly inequilateral, longitudinally elongated. Umbos

1540

1541

1542

1543

1544

1545

1546

1547

1548

1549

1550

1551

1552

1553

1554

1555

1556

1557

1558

1559

1560

1561

1562 terminal, probably prosogyrate. Posterior part rounded dorsal part rather straight, slightly

convex in posterior part, ventral margin convex. Anterior part without lobation. Hinge

unknown. Dorsal part with very prominent escutcheon delimited by ridges. Outer surface

scultpure of growth lines and rugae, inner surface sculpture with one prominent ridge visible

from escutcheon, directed posteroventrally. Muscle scars unknown.

Locality and horizon. Aitt Isioul ‘south’, central Anti-Atlas, Morocco, Lower Second Bani

Formation, Hirnantian Stage.

Genus Cleionychia Ulrich, 1892

Type species. By subsequent designation of Ulrich (1892, p. 97), Ambonychia lamellosa Hall, 1861 from the Upper Ordovician (Katian Stage) Platteville Formation at Mineral Point, opposite to Dubuque, State of Wisconsin, USA.

Cleionychia transversa (Portlock, 1843)

(Fig. 27f \& g)

*1843 Inoceramus transversus Portlock, p. 423, pl. 33, fig. 11.

1843 Inoceramus vetustus Portlock, p. 423, pl. 33, figs $2 \& 3$.

1952 Clionychia subovalis Reed, p. 76, pl. 4, fig. 7.

1952 Clionychia subquadrata Reed, pp. 76-77, pl. 4, fig. 8.

1982 Cleionychia transversa (Portlock). - Tunnicliff, p. 73, pl. 12, figs 1-6. 
Material. One left valve (MGM-6841X). Measurements are given in Table 11.

1565

Types. Lectotype, internal mould of the left valve figured by Tunnicliff (1982, pl. 12, fig. 1),

BGS GSM 12439. Paralectotypes: internal mould of the right valve figured by Tunnicliff

(1982, pl. 12, fig. 3), BGS GSM 12440; internal mould of the left figured by Tunnicliff (1982,

pl. 12, fig. 5), BGS GSM 24304.

1570

Type locality and horizon. Exact locality unknown but south of the Craigbardahessiagh,

Pomeroy, Ireland. Bardahessiagh Formation, Katian Stage.

Diagnosis. Cleionychia with long, straight dorsal margin, angle gamma about $90^{\circ}$.

Description. Shell equivalve, strongly inequilateral, transversally elongate. Umbos not prominent, in the anterior part of shell, terminal, prosogyrate, rising slightly the hinge line. Anterior margin straight, posterior margin rounded. Ventral margin convex, curving rapidly up to the anterior margin. Angle gamma about $90^{\circ}$, angle beta about $145^{\circ}$ (see Fig. 28). Hinge line straight, dentition unknown. The anterior adductor muscle scar rounded, far from the hinge line and very closed to the anterior margin. Inner surface sculpture is smooth. Outer surface sculpture is characterized by coarse rugae.

Remarks. Cleionychia transversa was described by Tunnicliff (1982) from the Late Ordovician of Ireland. Other species from Ireland (Cleionychia Prisca and Cleionychia incognita) were revised by Tunnicliff (1982). The main differences between these species are in the shape of the shell and the angles alpha and gamma. 
Locality and horizon (Moroccan material). Aït Isioul 'south', above bed G, central Anti-Atlas,

Morocco. Lower Second Bani Formation, Hirnantian Stage.

1591

*1843 Inoceramus vetustus Sowerby var. priscus Portlock. - Portlock, p. 423, pl. 33, fig. 1. 1878 Ambonychia undata Hall. - Baily, p. 28.

1952 Ambonychinia prisca (Portlock). - Reed, p. 73.

1982 Cleionychia prisca (Portlock). - Tunnicliff, p. 74, pl. 12, figs 8 \& 12.

Material. Two left valves, one articulated specimen, one right valve (specimens MGM6856X, MGM-6864X, MGM-6875X). Measurements are given in Table 12. (1982, pl. 12, fig. 8), UM K 4200.

Type locality and horizon. Portlock's (1843) locality, sheet 37, no. 6, south of 1610 acute $\left(80^{\circ}\right)$. 
1614

1615

1616

1617

1618

1619

1620

1621

1622

1623

1624

1625

1626

1627

1628

1629

1630

1631

1632

1633

1634

1635

1636

1637

Description. Shell equivalved, strongly inequilateral, ovate and inflated. Umbos

inconspicuous, in the anterior part of shell, terminal, prosogyrate, rising above the hinge line.

Posterior margin rounded. Ventral margin convex, curving rapidly up to the anterior margin.

Angle alpha about $50^{\circ}$, angle gamma about $80^{\circ}$ and angle beta about $120^{\circ}$ (see Fig. 28).

Hinge line straight, two cardinal teeth in the anterior part (Fig. 29g). Muscle scars unknown.

Inner surface of the shell is smooth. Outer surface sculpture consists of coarse rugae.

Remarks. Cleionychia prisca was originally described from the Late Ordovician of Ireland, Tunnicliff (1982) revised this species. Cleionychia prisca from Ireland also shows strong growth rugae and in this feature it differs from C. incognita Tunnicliff, 1982. In Moroccan specimens this character is not preserved. Cleionychia transversa is less oblique and less inflated while angle gamma is about $90^{\circ}$.

Localities and horizon (Moroccan material). Foum el Fehamya section, Aït Isioul 'north', central Anti-Atlas, Morocco. Lower Second Bani Formation, Hirnantian Stage.

\section{Order Cyrtodontida Nevesskaya et al., 1971}

Superfamily Cyrtodontoidea Ulrich, 1894 (in Ulrich \& Scofield, 1894)

Family Cyrtodontidae Ulrich, 1894 (in Ulrich \& Scofield, 1894)

Genus Cyrtodonta Billings, 1858

Type species. By original designation, Cyrtodonta rugosa Billings, 1858 from the Upper

Ordovician (Sandbian Stage) Chaumont Formation at the Paquette Rapids near Ottawa,

Canada. 
Cyrtodonta sp.

Material. Two articulated specimens, one left valve, one right valve (specimens MGM-

6859X, MGM-6863X, MGM-6868X, MGM-6869X). Measurements are given in Table 13.

Description. Shell large, ovate, equivalve, very inequilateral, becoming broader towards the posterior. Anterior part smaller than posterior, posterior part rounded. Dorsal and ventral margins convex. Umbos not prominent, terminal, prosogyrate. Ligament external, probably duplivincular. Muscle scars and pallial line not developed. Hinge unknown. Inner surface sculpture smooth. Outer surface sculpture unknown.

1650

Remarks. Cyrtodonta is well known from a variety of areas throughout the Ordovician

(Canada, Wales, Ireland, Sweden, China, Canada, United States, and the Czech Republic).

Identification to the species level is difficult, as in most species only the shape of the shell is known, while the other characters are rarely preserved.

1655

Localities and horizon. Aït Isioul 'north' and 'south', and the Foum el Fehamya section,

Infraclass Heteroconchia Hertwig, 1895 Cohort Uniomorphi Gray, 1854 
Type species. By original designation, Pseudarca typa Tromelin \& Lebesconte, 1875, p. 5, from the Upper Ordovician (Sandbian Stage) Grés de May Formation at Bouexière in the Armorican Massif, France.

\section{Pseudarca? sp.}

Material. One right valve (FSL 550155). Measurements are given in Table 14.

Description. Shell medium size, very elongated longitudinally, equivalve, strongly inequilateral. Umbo in the middle of the shell, rather orthogyrate. Anterior margin rounded, posterior margin truncate, dorsal margin in the posterior part slightly concave, ventral margin convex. Dentition and muscle scars are not visible. Inner surface is smooth.

Remarks. Babin \& Destombes (1990) figured this specimen and determined it as Modiolopsis? sp. It differs substantially from Modiolopsis in having very narrow and elongated shell, which is characteristic of Pseudarca. Pseudarca typa Tromelin \& Lebesconte, 1875 is known from the Late Ordovician (Katian) of France and Pseudarca celtica Tunnicliff, 1987 from the Late Ordovician (Katian) of North Wales. The specimen from Morocco has the characteristic shape of Pseudarca, but the other characters are unknown in this specimen. 
Locality and horizon. West of Akka Akka, Jbel Bani, western Anti-Atlas, Morocco. Lower Ktaoua Formation, Katian Stage.

\author{
Class Cephalopoda Cuvier, 1797 \\ Order Actinocerida Teichert, 1933 \\ Family Wademidae Özdikmen, 2008 \\ Genus Wadema Özdikmen, 2008
}

Type species. By original designation of Özdikmen (2008, p. 595), Georgina taylori (Wade, 1977), p 8, figs 3, 4, 6h-p, pl. 2, fig. 7, pl. 3 figs $1-6$ \& pl 4, fig. 1, from the Lower

Ordovician (Floian Stage) Coolibah Formation of the Georgina Basin, northern Australia.

Diagnosis. Orthocones with subcentral siphuncle; siphuncle expanded within chambers with adnate area at septa and small septal perforation; septal necks suborthochoantic in early growth stages to cyrtochoanitic and recumbent in later stages; siphuncular segments nonadnate to adnate; siphuncular deposits with variable number of engrafts and radial lamellae of annuli, endocameral deposits not known (after Wade 1977).

Wadema tattai sp. nov.

(Fig. 31a)

Holotype. Specimen AA.ABT.OS 38 figured herein as Fig. 31a.

Diagnosis. Wadema with relatively wide chamber distance of 0.45 of corresponding conch cross section; suborthochoantic septal necks, and relatively thin barrel-shaped siphuncular 
segments; siphuncle with maximum diameter c. 0.25 that of corresponding conch diameter.

Derivation of name. Referring to the type locality.

Material. Holotype only.

Type locality and horizon. SSE de Abdi bou Tatta, locality 6 of Destombes (2006b), west of Tazarine, east-central Anti-Atlas, Morocco. Upper Ktaoua Formation, Katian Stage.

Description. The holotype is a portion of a phragmocone with four chambers, $37 \mathrm{~mm}$ long and with a diameter of $24-29 \mathrm{~mm}$. The siphuncle is subcentral, with a distance of the septal perforation of c. $11 \mathrm{~mm}$ from the conch margin at a corresponding conch cross section of 27 $\mathrm{mm}$. The septal necks are suborthochoanitic. The siphuncular segments are barrel-shaped expanded within the chambers to a maximum diameter of $5.5 \mathrm{~mm}$ where the corresponding septal perforation is $2.8 \mathrm{~mm}$ and the corresponding conch cross section is $25 \mathrm{~mm}$. The siphuncular annuli are elongated with convex adapical and adoral margins and have well preserved lamellae. Siphuncular engrafts are preserved at mid-length between the septa (Fig. 31a), they are shallow with a length of $2 \mathrm{~mm}$ and a thickness of c. $0.7 \mathrm{~mm}$ at corresponding siphuncular diameter of $6.7 \mathrm{~mm}$. Endocameral deposits are not present. The conch surface is not preserved.

Remarks. The presence of siphuncular engrafts and the shape of the siphuncle and septal necks justifies the assignment of this species to Wadema. The Australasian specimens are all considerably older (late Floian Stage). 

Thailand (Stait \& Burrett 1984), and tentatively from Saudi Arabia and Bolivia (Evans 2000), suggesting a circum-Gondwana distribution of this group during the Mid Ordovician. The Moroccan occurrence is the youngest report of a wademid cephalopod so far.

Wadema sp. (Fig. 32e)

Material. Specimen MGM-7013X.

Locality and horizon. Locality Jbel Bou Ingarf 'north', eastern Anti-Atlas, Morocco. Upper

Ktaoua Formation, Katian Stage.

Description. The specimen is an internal mould of a portion of a phragmocone with two chambers. The specimen is $37 \mathrm{~mm}$ long and with a diameter of $51-52 \mathrm{~mm}$. The siphuncle is subcentral, with a distance of the septal perforation of c. $14 \mathrm{~mm}$ from the conch margin and a diameter of $9 \mathrm{~mm}$ at a corresponding conch cross section of $51 \mathrm{~mm}$. The septal necks are suborthochoantic. The siphuncular segments are expanded within the chambers. The endosiphuncular annuli have convex adoral margins and well preserved lamellae. The conch surface is not preserved.

Remarks. The general conch morphology (distance of chambers, position of siphuncle, presence of annuli with lamellae) is similar to Wadema tattai sp. nov. but internal characters, such as connecting ring shape and engrafts are not preserved, an do not permit more specific determination of this specimen. 
Material. Specimen MGM-7014X.

Locality and horizon. Jbel Bou Ingarf ‘north', eastern Anti-Atlas, Morocco. Uppermost beds of the Upper Ktaoua Formation, Katian Stage.

Description. The specimen is a fragmentary internal mould of a portion of a phragmocone with three chambers, $20 \mathrm{~mm}$ long and with a diameter of $44 \mathrm{~mm}$. The siphuncle is subcentral, with a distance of the centre of the septal perforation of c. $17 \mathrm{~mm}$ from the conch margin and a maximum siphuncular diameter of $16 \mathrm{~mm}$. The shape of the septal necks is not preserved.

The siphuncular segments are expanded within the chambers. The siphuncular annuli have convex adoral and adapical margins and well preserved lamellae. The conch surface is not preserved.

Remarks. The general conch morphology (distance of chambers, position of siphuncle, presence of annuli with lamellae) is similar to other ormoceratids, but internal characters, such as septal neck shape and conch surface are not preserved, not permitting a determination at genus level or higher. 
Type species. Tafadnatoceras tiouririnense sp. nov. from the Upper Ordovician (Katian

Stage), Upper Tiouririne Formation at Tafilalt, eastern Anti-Atlas, Morocco.

Diagnosis. Slightly curved orthocones with central siphuncle; siphuncle expanded within chambers with adnate area at septa and small septal perforation; septal necks cyrtochoanitic and adnate during late growth stages; with siphuncular lining composed of stacked layers of parietal deposits; with cameral deposits.

Derivation of name. Referring to the Tafilalt type region and the superficial similarity to Adnatoceras Flower, 1939. The gender is neuter.

Remarks. This new genus is similar to the late Palaeozoic Adnatoceras Flower, 1939 and the

Mid Ordovician Paradnatoceras Chen \& Liu (1974) in having a slender central siphuncle with adnate connecting ring and septal necks and a siphuncle that expands abruptly at the septal foramen.

Tafadnatoceras gen. nov. differs from these two genera in having a continuous lining inside the siphuncle. Such a combination of cyrthochoanitic septal necks and a continuous siphuncular lining is otherwise known only from stereoplasmocerids. Adnatoceras is a spyroceratid and Paradnatoceras has discontinuous parietal siphuncular deposits (Fig. 33b). Hence the new genus is a stereoplasmocerid, uniquely characterized by septal necks and siphuncular segments adnate to the septa. 
ornamentation and non-adnate cyrtochoanitic septal necks.

Holotype. Specimen MGM-7005X figured herein as Figs 32b \& 34d.

Tafadnatoceras tiouririnense sp. nov.

(Figs 32a, b, 33a \& 34a-d)

Diagnosis. Slightly curved orthocones, with angle of expansion of up to c. $7^{\circ}$, smooth conch surface or ornamented with very fine irregularly spaced rugae or growth lines; conch cross section circular; siphuncle centrally positioned, with septal perforation diameter of c. $0.07 \mathrm{~mm}$ of corresponding conch diameter; siphuncular segments expanded, barrel-shaped; maximum expansion of sipuncle at mid-length with diametre of c. 0.2 of corresponding conch diameter, connecting ring adnate at septa, septal necks cyrtochoanitic, adnate, except in earliest growth stage; siphuncular deposits form continuous lining; massive episeptal and hyposeptal deposits.

Derivation of name. Referring to type horizon.

Material. Nine additional specimen, MGM-7003X \& MGM-7006X-MGM-7012X, and one specimen MGM-7004X from locality Erfoud 2; all from the Upper Tiouririne Formation, Katian Stage.

Type locality and horizon. Erfoud 2, Tafilalt, eastern Anti-Atlas, Morocco. Upper Tiouririne Formation, Katian Stage. 
Description. The holotype is a portion of a phragmocone with a length of $22 \mathrm{~mm}$ and a diametre of 5.5-6.8 $\mathrm{mm}$ (angle of expansion $6^{\circ}$ ). The conch cross section is circular. The chamber height varies between $1.8-2.5 \mathrm{~mm}(0.33-0.38$ of the corresponding conch cross section). The conch surface is nearly smooth with very fine irregularly spaced transverse rugae or growth lines. The siphuncle is central with very narrow septal perforation (c. 0.7 of corresponding conch cross section), barrel-shaped outline in median section, adnate in adoral part of the specimen, less expanded in adapical parts. Septal necks cyrtochoanitic and adnate in adoral part of specimen. Parietal siphuncular deposits form thin continuous lining, which is thicker on the "ventral" side (Figs 33a \& 34d). Massive, irregular episeptal and hyposeptal deposits occur.

Specimen MGM-7003X is a portion of a slightly curved phragmocone with a length of 25 $\mathrm{mm}$ and a conch diameter of 2.6-5.4 $\mathrm{mm}$ with circular conch cross section. The adapical chamber spacing is wider than the adoral spacing with a chamber distance of $0.3-0.6$ of the corresponding conch cross section (Fig. 34c). The siphuncle is central and is nearly tubular in its extreme adapical part, becoming more expanded and barrel-shaped within the adapical 10 mm (Fig. 34a). The septal necks are cyrtochoanitic, they are adnate only in the adoral part of the specimen. The siphuncle is empty. Episeptal and hyposeptal deposits are irregular and mural deposits are more massive in the adapical part of the specimen. The largest specimen in the collection is MGM-7009X with a maximum diameter of $19 \mathrm{~mm}$, and a length of $58 \mathrm{~mm}$. The fragment of the phragmocone has an angle of expansion of $6.5^{\circ}$, and a chamber distance of up to 0.35 of the corresponding conch cross section.

Remarks. The adult size of this species is not known. The available fragments reveal a change in siphuncle shape in the earliest growth stages toward a diameter of c. $3 \mathrm{~mm}$, with a more tubular siphuncle and non-adnate connecting rings and septal necks. 
The early growth stages with nearly tubular connecting rings and less curved septal necks,

1861

1862

1863

1864

1865

1866

1867

1868

1869

1870

1871

1872

1873

1874

1875

1876

1877

1878

1879

1880

1881

1882

1883

1884

preserved in one of the specimens described herein, are important because they link cyrtochoanitic stereoplasmoceratids morphologically with other suborthochoanitic orthocerids with more discontinuous parietal deposits. This new link and the presence of a continuous siphuncular lining, formed by stacked layers of parietal deposits justifies a classification of the Stereoplasmoceridae within the Orthocerida.

Order Endocerida Teichert, 1933

Family Endoceratidae Hyatt, 1884

Endoceratidae gen. et sp. indet.

Figures $32 \mathrm{c} \& \mathrm{~d}$

Material. Nine specimens MGM-6994X-MGM-7002X.

Locality and horizon. SW of Alnif, about $5.8 \mathrm{~km}$ northeast from the town of Aachich n'Ait Azza, eastern Anti-Atlas, Morocco. Taddrist Formation (First Bani), Sandbian Stage.

Description. The specimens are all fragmentary inner moulds of phragmocones with apparently smooth conch surface, circular conch cross section and marginal siphuncles. The siphuncles, if preserved are nearly tubular or slightly concavo-convex with holochoanitic septal necks (Fig. 32c). Specimen MGM-6994X is a fragment with a length of $35 \mathrm{~mm}$ and a diameter of 36-38 mm.; it has a chamber distance of $7 \mathrm{~mm}$ and a siphuncular diameter of 17 $\mathrm{mm}$ at a corresponding conch cross section of $38 \mathrm{~mm}$. Specimen MGM-6997X is a fragment with a diameter of $47 \mathrm{~mm}$ and a corresponding siphuncular diameter of $20 \mathrm{~mm}$ and a chamber distance of $8 \mathrm{~mm}$. Specimen MGM-7001X has a length of $54 \mathrm{~mm}$ is $45-48 \mathrm{~mm}$ wide and has 
a diameter of $21 \mathrm{~mm}$ and a chamber distance of $10 \mathrm{~mm}$ at a corresponding conch cross section of $48 \mathrm{~mm}$. No siphuncular deposits are preserved in these specimens.

Remarks. The general conch morphology (smooth conch surface, depth of chambers, position of siphuncle, presence of holochoanitic septal necks) are similar to other endoceratids, but internal characters, such as the endosiphocone shape and early ontogenetic growth stages are not preserved, negating a determination at genus level or higher.

\section{Discussion}

The mollusc assemblage of the Late Ordovician of central and eastern Morocco is diverse with more than 30 taxa documented. Most taxa are from the Sandbian to Katian Lower Ktaoua Group and the Hirnantian portion of the Lower Second Bani Formation. Tergomyan and gastropods are represented by 14 species, two which are tergomyans, four are bellerophontiform gastropods, and eight are anisostrophically coiled gastropods. The widely recognized Holopea? antiquata is transferred to the genus Radvanospira gen. nov.; other new gastropod taxa include Allossospira gen. nov., Tritonophon grandis sp. nov., Radvanospira baniensis sp. nov., and Lophospira latilabra sp. nov.

The bivalve assemblage is relatively diverse, including 13 taxa, although most of them are left in open nomenclature: Ambonychia aff. magna, Ambonychia sp., Praenucula pojetai sp. nov., Cleionychia prisca, Cleionychia transversa, Cyrtodonta sp., Dceruska sp., Modiolopsis sp., Myoplusia sp., Nuculites sp., Phestia? sp., Pseudarca? sp., and Sluha kosoviensis. They are mostly preserved as isolated valves and articulated specimens are rare. There is a clear dominance of pteriomorphs and protobranchs, while the dominating elements in the Early Ordovician bivalves from Morocco are heteroconchs. The life habits of Moroccan Late 
Ordovician bivalves are varied, from infaunal and semi-infaunal to epifaunal. In contrast, the Early Ordovician bivalves from Morocco were entirely infaunal.

Five cephalopod taxa are recognized but except for two taxa they are left in open nomenclature. Tafadnatoceras tiouririnense gen. et. sp. nov. from the Upper Tiouririne Formation is similar to the late Palaeozoic Adnatoceras Flower, 1939 and the Mid Ordovician Paradnatoceras Chen \& Liu (1974).

The cool-water, high-latidtude Mediterranean province of southern Gondwana is wellestablished (Gutierrez-Marco et al. 2017). Widespread Late Ordovician shallow water benthic assemblages dominate but the knowledge of many groups are still sketchy, as demonstrated by the molluscan fauna described herein. The bivalve fauna, which shows strong affinities with contemporaneous bivalve faunas in Bohemia, Ireland, and Baltica, was until now practically unknown and the cephalopods described herein represent the first systematically known from the region. A surprising result is the presence of the actinocerid genus Wadema in Morocco otherwise known from low palaeolatitude Gondwana faunas as far away as Australia and Thailand. Characteristic peri-Gondwanan faunal elements are lacking in Morocco but this may be an artefact because of insufficient knowledge of the cephalopod fauna of large parts of especially eastern Gondwana (Kröger 2013). The tergomyan and gastropod faunas are better known. Late Ordovician records from Morocco showed prior to the present work a high percentage of widespread genera (Ebbestad et al. 2013b), but the new definitions of Radvanospira and Allossospira emphasises better the southern Gondwana aspect of the assemblage. Genera like Sinuitopsis, Bucanopsis, and Nonorios are in common with Bohemia, Deaechospira is shared with Baltica and Bohemia, while Tritonophon and Lophospira are more widely spread genera. The latter taxon, e.g. Lophospira latilabra, is a representative of a generally warm-water genus. 
Acknowledgements

We cordially thank drs Aaron Hunter and Bertrand Lefebvre for inviting us to write this chapter and dr Peter van Roy for handling the editorial aspects. JORE wish to thank the members of the Department of Palaeontology in Prague, and especially drs Martin Valent and František Vacek, for help and access to the collections. MP would like to thank John Cope for providing important literature and valuable suggestion to systematics. The authors wish to express their gratitude to Julio Martín Sánchez and Saturnino Lorenzo for the field assistance to JCG-M. Comments from drs John C. W. Cope, David H. Evans, and Jan Audun Rasmussen greatly improved the manuscript. This is a contribution to SYNTHESYS CZ-TAF-6578 awarded to JORE. This work was funded by Grant Agency of the Czech Republic Project No.18-14575S and internal project of the Czech Geological Survey number 339900 to MP. Field-work in Morocco (JCG-M) was supported by project CGL2017-87631-P of the Spanish Ministry of Science, Innovation and Universities. This paper is a contribution to project IGCP 653 'The onset of the Great Ordovician Biodiversification Event'. 
Adams, H. \& Adams, A. 1854-1858. The genera of Recent Mollusca arranged according to their organization. J. van Vorst, London.

Álvaro, J.J., Benharref, M., Destombes, J., Gutiérrez-Marco, J.C., Hunter, A.W., Lefebvre, B., Van Roy, P. \& Zamora, S., this volume. Ordovician stratigraphy and benthic community replacements in the eastern Anti-Atlas, Morocco. In: Hunter, A.W., Álvaro, J.J., Lefebvre, B., van Roy, P. \& Zamora, S. (eds) The Great Ordovician Biodiversification Event: Insights from the Tafilalt Biota, Morocco. Geological Society, London, Special Publications, 485, \#\#\#-\#\#\#.

Babin, C. 1966. Mollusques Bivalves et Céphalopodes du Paléozoïque armoricain. Imprimerie Commerciale et Administrative, Brest.

Babin, C. \& Destombes, J. 1990. Les Mollusques Bivalves et Rostroconches ordoviciens de 1'Anti-Atlas marocain: Intérêt paléogéographique de leur inventaire. Géologie Méditerranéenne, 17, 243-261.

Babin, C., \& Gutiérrez-Marco, J.C. 1991. Middle Ordovician Bivalves from Spain and their phyletic and palaeogeographic significance. Palaeontology, 34, 109-147.

Babin, C. \& Hamman, W. 2001. Une nouvelle espèce de Modiolopsis (Bivalvia) dans l'Arenig (Ordovicien inférieur) de Daroca (Aragon, Espagne); réflexions sur la denture des bivalves primitifs. Revista Española de Paleontología, 16, 269-282.

Babin, C. \& Beaulieu, G. 2003. Les Mollusques Bivalves de l'Ordovicien de Saint-Clémentde-la-Place (Maine-et-Loire, sud-est du Massif Armoricain). Bulletin de la Société Scientifique Naturelle Ouest de la France, nouvelle série, 25, 177-206.

Bandel, K. 1992. Platyceratidae from the Triassic St. Cassian Formation and the evolutionary history of the Neritomorpha (Gastropoda). Paläontologische Zeitschrift, 66, 231-240. 
Baily, W.H. 1878. Paleontological Notes. In Nolan, J., Explanatory Memoir to accompany sheet 34 of the maps of the Geological Survey of Ireland. Memoirs of the Geolological Survey.

Barrande, J. 1877. Systême Silurien du centre de la Bohême. lère partie: Recherches Paléontologiques, Vol. II. Classe des Mollusques. Ordre des Céphalopodes. Supplement et Série Tardive. Texte. Chez l'auteur et éditeur, Prague.

Barrande, J. 1881a. Systême Silurien du centre de la Bohême. lère Partie: Recherches Paléontologiques. Vol. VI. Classe des Mollusques. Ordre des Acéphalés. Quatre chapitres de texte et Planches 1 à 48. Chez l'auteur et éditeur, Prague.

Barrande, J. 1881b. Systême Silurien du centre de la Bohême. lère Partie: Recherches Paléontologiques. Vol. VI. Classe des Mollusques. Ordre des Acéphalés. Planches 49 à 154. Chez l'auteur et éditeur, Prague.

Barrande, J. 1881c. Systême Silurien du centre de la Bohême. lère Partie: Recherches Paléontologiques. Vol. VI. Classe des Mollusques. Ordre des Acéphalés. Planches 155 à 254. Chez l'auteur et éditeur, Prague.

Barrande, J. 1881d. Systême Silurien du centre de la Bohême. lère Partie: Recherches Paléontologiques. Vol. VI. Classe des Mollusques. Ordre des Acéphalés. Planches 255 à 361. Chez l'auteur et éditeur, Prague.

Bassler, R.S. 1915. Bibliographic index of American Ordovician and Silurian fossils. United States National Museum, Bulletin, 92, 1-1521.

Bergström, S.M., Chen, X., Gutiérrez-Marco, J.C. \& Dronov, A. 2009. The new chronostratigraphic classification of the Ordovician System and its relations to major regional series and stages and to $\delta 13 \mathrm{C}$ chemostratigraphy. Lethaia, 42, 97-107. 
Beurlen, K. 1944. Beiträge zur Stammesgeschichte der Muscheln. Sitzungsberichte. Bayerische Akademie der Wissenschaften, Mathematisch-Naturwissenschaftliche Klasse 1-2, 133-145.

Billings, E. 1858. On the Asteridae of the Lower Silurian rocks of Canada. Figures and descriptions of Canadian organic remains. Geological Survey of Canada, 3, 75-85.

Blodgett, R.B, Frýda, J. \& Racheboeuf, P.R. 1999. Upper Middle Devonian (Givetian) Gastropods from the Kersadiou Formation, Brittany, France. Journal of Paleontology, 73, $1081-1100$.

Bouchet, P. \& Rocroi, J.-P. 2005. Part 1. Nomenclator of Gastropod Family-Group Names. In: Bouchet, P. \& Rocroi, J.-P. Classification and nomenclator of gastropod families. Malacologia, 47, 1-397.

Boucot, P. \& Yochelson, E.L. 1966. Paleozoic Gastropoda from the Moose River Synclinorium, Northern Maine. Professional Papers of the. U. S. geological Survvey, 503A, 1-20.

Born, A. 1918. Die Calymene tristani-Stufe (mittleres Untersilur) bei Almaden, ihre Fauna, Gliederung und Verbreitung. Abhandlungen der senckenbergischen naturforschenden Gesellschaft, 36, 309-358.

Bradshaw, M.A. 1970. The dentition and musculature of some Middle Ordovician (Llandeilo) Bivalves from Finistère, France. Palaeontology, 13, 623-645.

Bradshaw, M.A. 1999. Lower Devonian bivalves from the Reefton Group, New Zealand. Memoir of the Association of Australasian Palaeontologists, 20, 1-171.

Bretsky, P.W. 1970. Upper Ordovician ecology of the central Appalachians. Peabody Museum of Natural History, Bulletin, 34, 1-150. 
Bretsky, S.S. \& Bretsky, P.W. 1977. Morphological variability and change in the palaeotaxodont bivalve mollusk Nuculites planulatus (Upper Ordovician of Quebec). Journal of Paleontology, 51, 256-271.

Carls, P. 1975. The Ordovician of the Eastern Iberian Chains near Fombuena and Luesma (Prov. Zaragoza, Spain). Neues Jahrbuch für Geologie und Paläontologie Abhandlungen, 150, 127-146.

Chen, Jun-yuan \& Liu, Geng-wu 1974. Ordovician and Silurian Nautiloidea. In: Nanking Institute of Geology and Paleontology. Academia Sinica (ed.) A Handbook of the Stratigraphy and Paleontology in Southwest China. Science Press, Beijing, 138-143, 190194.

Caley, J.F. 1936. Part II: The Ordovician of Manitoulin Island, Ontario. In: Wilson, A.E., Caley, J.F., Sproule, J.C. \& Okulitch, V.K. (eds) Contributions to the Study of the Ordovician of Ontario and Quebec. Canada Department of Mines, Bureau of Economic Geology, Geological Survey of Canada, Ottawa, Memoirs, 202, 21-92.

Carter, J.G., Altaba, C.R., Anderson, L.C., Araujo, R., Biakov, A.S., Bogan, A.E., Campbell, D.C., Campbell, M., Chen, J., Cope, J.C.W., Delvene, G., Dijkstra, H.H., Fang, Z., Gardner, R.N., Gavrilova, V.A., Goncharova, I.A., Harries, P.J., Hartman, J.H., Hautmann, M., Hoeh, W.R., Hylleberg, J., Jiang, B., Johnston, P., Kirkendale, L., Kleemann, K., Koppka, J., Kř́̌ž, J., Machado, D., Malchus, N., Márquezaliaga, A., Masse, J.P., MC, Roberts, C.A., Middelfart, P.U., Mitchell, S., Nevesskaya, L.A., Özer, S., Pojeta, J. jr., Polubotko, I.V., Pons, J.M., Popov, S., Sánchez, T., Sartori, A.F., Scott, R.W., Sey, I.I., Signorelli, J.H., Silantiev, V.V., Skelton, P.W., Steuber, T., Waterhouse, J.B., Wingard, G.L. \& Yancey, T. 2011. A synoptical classification of the Bivalvia (Mollusca). University of Kansas, Paleontological Institute, Paleontological Contributions, 4, 1-47. 
2042

2043

2044

2045

2046

2047

2048

2049

2050

2051

2052

2053

2054

2055

2056

2057

2058

2059

2060

2061

2062

2063

2064

2065

Cherns, L. Wheeley, J.R. \& Wright, V.P. 2008. Taphonomic windows and molluscan preservation. Palaeogeography, Palaeoclimatology, Palaeoecology, 270, 220-229.

Chernyshev, B.I. 1939. Tip Myagkotelyye-Molluska, Klass Atlas rukovodyashchikh from isokopayemykh faun SSSR. Sdreniy i verkhniy otdely kamennougl' noy sistemy. Tsentral' nyy Nauchno-Issledovatel' skiy Geologo-Razvedochnyy Institut, 5, 113-126 [in Russian].

Chernyshev, B.I. 1951. Semeistvo Ledidae iz Kammenougol'nykh otlozhenii SSSR. Trudy Instituta Geologicheskikh Nauk, Akademii Nauk Ukrainskoi SSR, Seriya Stratigrafii i Paleontlogii, 2, 1-40 [in Russian].

Conrad, T.A. 1838. Report on the palaeontological department of the survey (of New York). New York Geological Survey Annual Report, 2, 107-119.

Conrad, T.A. 1841. Annual report of the paleontology of the State of New York. New York Geological Survey Annual Report, 5, 25-57.

Cope, J.C.W. 1997. The early phylogeny of the class Bivalvia. Palaeontology, 40, 713-746.

Cope, J.C.W. 1999. Midle Ordovician bivalves from Mid-Wales and the Welsh Borderland. Palaeontology, 42, 467-499.

Cope, J.C.W. 2002. Diversification and biogeography of bivalves during the Ordovician Period. In: Crame, J.A. \& Owen, A.W. (eds.) Palaeobiogeography and Biodiversity Change: A Comparison of the Ordovician and Mesozoic-Cenozoic Radiations. Geological Society, London, Special Publications, 194, 35-52.

Cope, J.C.W. 2004. Bivalve and Rostroconch mollusks. In: Webby, B.D., Paris, F., \& Droser, Percival, I.G. (eds.) The Great Ordovician Biodiversification Event. Columbia University Press. New York, 196-208.

Cope, J.C.W. \& Babin, C. 1999. Diversification of bivalves in the Ordovician. Geobios, 32, $175-185$. 
2066

2067

2068

2069

2070

2071

2072

2073

2074

2075

2076

2077

2078

2079

2080

2081

2082

2083

2084

2085

2086

2087

2088

2089

Cope, J.C.W. \& Kříž, J. 2014. The Lower Palaeozoic palaeobiogeography of Bivalvia. Geological Society of London Memoir, 38, 221-241.

Cossmann, M. 1904. Essais de Paléoconchologie comparée 6. Chez l'auteur, Paris.

Cuvier, G. 1797. Tableau élémentaire de l'histoire naturelle des animaux. Baudouin, Paris.

Dall, W.H. 1889. On the hinge of pelecypods and its development, with an attempt toward a better subdivision of the group. American Journal of Science and Arts (Series 3), 38, 445462.

Destombes, J. 1983. Notice explicative (Cambrien moyen, Ordovicien, base du Silurien) de la Carte géologique du Maroc au $200000^{2 e ̀ ~ d e ~ l ' A n t i-A t l a s ~ m a r o c a i n . ~ C h a p i t r e ~ A: ~ F e u i l l e s ~}$ Zagora-Coude du Dra-Hamada du Dra. Rapport Interne du Service de la Carte géologique du Maroc, Rabat (48 pp., unpubl.).

Destombes, J. 2006a. Carte géologique au $200000^{\circ}$ de l'Anti-Atlas marocain. Paléozoïque inférieur: Cambrien moyen et supérieur - Ordovicien - base du Silurien. Sommaire général sur les mémoires explicatifs des cartes géologiques au 1/200 000 de l'Anti-Atlas marocain. Notes et Mémoires du Service Géologique du Maroc, 515, 1-150.

Destombes, J. 2006b. Carte géologique au 1/200 000 de l'Anti-Atlas marocain. Paléozoïque inférieur. Cambrien moyen et supérieur-Ordovicien-base du Silurien. Feuille ZagoraCoude du Dra. Mémoire explicatif, Chapitre A. Notes et Mémoires du Service Géologique du Maroc, 273, 1-36.

Destombes, J., Hollard, H. \& Willefert, S. 1985. Lower Palaeozoic Rocks of Morocco. In: Holland, C.H. (ed.) Lower Palaeozoic Rocks of the World. Volume 4: Lower Palaeozoic of North Western and West Central Africa. Wiley, New York, 91-336.

Dzik, J. 1981. Larval development, musculature, and relationships of Sinuitopsis and related Baltic bellerophonts. Norsk geologisk Tidsskrift, 61, 111-121. 
Ebbestad, J.O.R. 1999. Bucaniid gastropods from the Upper Ordovician of Baltica, with a discussion of the Bucaniinae. Palaeontology, 42, 149-169.

Ebbestad, J.O.R. 2008. The tergomyan mollusc Carcassonnella from the Upper Ordovician of Girvan, Scotland. Palaeontology, 51, 663-675.

Ebbestad, J.O.R. 2016. Gastropoda, Tergomya and Paragastropoda (Mollusca) from the Lower Ordovician Fezouata Formation, Morocco. Palaeogeography, Palaeoclimatology, Palaeoecology, 460, 87-96.

Ebbestad, J.O.R. \& Peel, J.S. 2001. An unusual trochiform gastropod from the Upper Ordovician of Sweden. Palaeontology, 44, 375-387.

Ebbestad, J.O.R. \& Stott, C. 2008. Failed predation in Late Ordovician gastropods (Mollusca) from Manitoulin Island, Ontario, Canada. Canadian Journal of Earth Sciences, 45, 231241.

Ebbestad, J.O.R., Bassett, M.G., Dastanpour, M. \& Popov, L.E. 2008. Ordovician (Caradoc) Gastropoda of the Katkoyeh Formation, Kerman Province, Iran. Geobios, 41, 605-624.

Ebbestad, J.O.R., Högström, A.E. \& Frisk, Å.M. 2013a. Gastropods and tergomyans from the Upper Ordovician (Viru-Harju) of the Fågelsång area, Scania, southern Sweden. Journal of Systematic Palaeontology, 11, 295-336.

Ebbestad, J.O.R., Frýda, J., Wagner, P.J., Horný, R.J., Isakar, M., Stewart, S., Percival, I.G., Bertero, V., Rohr, D.M., Peel, J.S., Blodgett, R.B. \& Högström, A.E.S. 2013b.

Biogeography of Ordovician and Silurian gastropods, monoplacophorans and mimospirids. In: Harper, D.A.T. \& Servais, T. (eds) Early palaeozoic biogeography and palaeogeography. Geological Society London Memoirs, 38, 199-220.

Engeser, T. \& Riedel, F. 1996. The evolution of the Scaphopoda and its implications for the systematics of the Rostroconchia (Mollusca). Mitteilungen Geologisch-Paläontologisch Institut Universität Hamburg, 79, 117-138. 
Evans, D.H. 2000. A cephalopod fauna from the middle Ordovician of Saudi Arabia. Palaeontology, 43, 573-589.

Fatka, O., Mikuláš, R., Szabad, M., Micka, V. \& Valent, M. 2011. Arachnostega Bertling, 1992 in the Drumian (Cambrian) sediments of the Teplá-Barrandian region (Czech Republic). Acta Geologica Polonica, 61, 367-381.

Férussac, A.E.J. \& D’Audebard, D.E. 1821-1822. Tableaux Systèmatiques des Animaux Mollusques suivis d'un Prodrome Général pour tous les Mollusques Terrestres ou Fluviatiles Vivants ou Fossiles. Première Partie, Tableaux Systématiques Généraux. Arthus-Bertrand \& Sowerby, Paris \& London.

Fischer, P.H. 1886. Manuel de Conchyliologie et de Paléontologie Conchyliologique, ou Histoire Naturelle des Mollusques Vivants et Fossiles suivi d'un Appendice sur les Brachiopodes par D. P. Oehlert. Avec 23 planches contenant 600 figures dessinées par $S$. P. Woodward. Savy, Paris.

Flower, R.H. 1939. Study of Pseudorthoceratidae. Palaeontographica Americana, 11, 1-214.

Frey, R.C. 1987. The paleoecology of a Late Ordovician shale unit from southwest Ohio and southeastern Indiana. Journal of Paleontology, 61, 242-267.

Frisk, Å.M. \& Ebbestad, J.O.R. 2007. Paragastropoda, Tergomya, and Gastropoda (Mollusca) from the Upper Ordovician Dalby Limestone, Sweden. GFF, 129, 83-99.

Frýda, J. 1999. Higher classification of Paleozoic gastropods inferred from their early shell ontogeny. Journal of the Czech Geological Society, 44, 137-153.

Frýda, J. \& Bouchet, P. 2005. Paleozoic molluscs of uncertain systematic position, Neritimorpha, fossil "archaeogastropods", fossil lower caenogastropods and fossil lower Heterobranchia. In: Bouchet, P. \& Rocroi, J.-P. Classification and nomenclator of gastropod families. Malacologia, 47, 1-397. 
Frýda, J. \& Gutiérrez-Marco, J.C. 1996. An unusual new sinuitid mollusk (Bellerophontoidea, Gastropoda) from the Ordovician of Spain. Journal of Paleontology, 70, 602-609.

Frýda, J. \& Rohr, D.M. 2004. Gastropods. In: Webby, B.D., Paris, P., Droser, M.L. \& Percival, I. G. (eds) The Great Ordovician Biodiversification Event. Columbia University Press, New York, 184-195.

Frýda, J., Nützel, A. \& Wagner, P. 2008. Paleozoic gastropods. In: Ponder, W.F. \& Lindberg, D.R. (eds) Phylogeny and Evolution of the Mollusca. University of California Press, 239270.

Frýda, J., Racheboeuf, P.R., Frýdová, B., Ferrová, L., Mergl, M. \& Berkyová, S. 2009. Platyceratid gastropods - stem group of patellogastropods, neritimorphs or something else? Bulletin of Geosciences, 84, 107-120.

Ghavidel-Syooki, M., Evans, D.H., Ghobadi Pour, M., Popov, L.E., Álvaro, J.J., Rakhmonov, U., Klishevich, I.A. \& Ehsani, M.H. 2015. Late Ordovician cephalopods, tentaculitides, machaeridians and echinoderms from Kuh-e Faraghan, High Zagros, Iran. Alcheringa, 39, $530-549$.

Gil Cid, M.D. \& Lebrón Moreno, J.A. 2010. Taphonomy of trilobites and associated invertebrates from SW Spain and NW Portugal. Neues Jahrbuch für Geologie und Paläontologie, Abhandlungen, 257, 169-179.

Gray, J.E. 1824. A supplement to the Appendix of Captain Perry's voyage for the discovery of a North West Passage, in the years 1819-1820, containing an account of the subjects of natural history. In: Parry, E.W. (ed.) Journal of a Second Voyage for the Discovery of a Northwest Passage from the Atlantic to the Pacific, Performed in the Years 1821-22-23, in His Majesty's Ships Fury and Hecla, under the Orders of Captain William Edward Parry, R.N., F.R.S. Appendix X. Natural History, Shells. Murray, London, ccxl-ccxlvi. 
Gray, J.E. 1854. A revision of the arrangement of the families of bivalve shells (Conchifera). The Annals and Magazine of Natural History (Series 2), 13, 408-418.

Grobben, K. 1894. Zur Kenntniss der Morphologie, Verwandschaftsverhältnisse und des Systems der Mollusken. Sitzungsberichte der Kaiserlichen Akademie der Wissenschaften. Mathematisch-Naturwissenschaftliche Klasse, 103, 61-86.

Gutiérrez-Marco, J.C. 1984. Una interesante señal de actividad biológica en el Ordovícico de los Montes de Toledo. Coloquios de Paleontología, 39, 17-25.

Gutiérrez-Marco, J.C. \& Vinn, O. 2018. Hirnantian cornulitids (tubeworms) from near the Ordovician South Pole. Journal of African Earth Sciences, 137, 61-68.

Gutiérrez-Marco, J.C., Rábano, I., Sarmiento, G.N., Aceñolaza, G.F., San José, M.A., Pieren, A.P., Herranz, P., Couto, H.M. \& Piçarra, J.M. 1999. Faunal dynamics between Iberia and Bohemia during the Oretanian and Dobrotivian (late Middle-earliest Upper Ordovician), and biogeographic relations with Avalonia and Baltica. Acta Universitatis Carolinae Geologica, 43, 487-490.

Gutiérrez-Marco, J.C., Aramburu, C., Arbizu, M., Méndez-Bedia, I., Rábano, I., Truyols, J. \& Villas, E. 1997. Caracterización estratigráfica del Ordovícico Superior en el Manto de Mondoñedo (Zona Asturoccidental-leonesa, NO de España): primeras dataciones paleontológicas y correlación. In: Grandal d'Anglade. A., Gutiérrez-Marco, J.C. \& Santos Fidalgo, L. (eds) Comunicaciones XIII Jornadas de Paleontología y V Reunión Internacional PIGC 351, A Coruña, 33-37.

Gutiérrez-Marco, J.C., Sá, A.A., Rábano, I., Sarmiento, G.N., García-Bellido, D.C., Bernárdez, E., Lorenzo, S., Villas, E., Jiménez-Sánchez, A., Colmenar, J. \& Zamora, S. 2015. Iberian Ordovician and its international correlation. Stratigraphy, 12, 257-263. 
Gutiérrez-Marco, J.C., Sá, A.A., García-Bellido, D.C. \& Rábano, I. 2017. The BohemoIberian regional chronostratigraphical scale for the Ordovician System and palaeontological correlations within South Gondwana. Lethaia, 50, 258-295.

Hadding, A. 1913. Undre Dicellograptusskiffern in Skåne jämte några därmed ekvivalenta bildningar. Lunds Universitets Årsskrift, Ny Följd 2, 9, 1-91.

Hall, J. 1847. Natural History of New York. Palaeontology. Vol. 1. Geological Survey of New York.

Hall, J. 1859. Contributions to the palaeontology of New York; being some of the results of investigations during the years 1855, 1856, 1857, and 1858. Twelfth Annual Report of the Regents of the University of the State of New York on the condition of the State Cabinet of Natural History and the Historical and Antiquarian Collection connected therewith, 8 110.

Hall, J. 1861. Contributions to Palaeontology, comprising descriptions of new fossils from the Upper Helderberg, Hamilton and Chemung groups. Annual report of the Regents of the University of the State of New York on the State Cabinet of Natural History and Historical and Antiquarian collection annexed there to, 15, 29-155.

Hall, J. 1879. Natural history of New York. Geological Survey of New York. Palaeontology, Vol. 5, Part 2. Text et Plates. Van Benthuysen \& Sons, Albany.

Hall, J. 1883-1884. Natural History of New York. Paleontology of New York. Geological Survey of New York. Paleontology. Vol. 5, Part 1. Lamellibranchiata I. Containing Descriptions and Figures of the Monomyaria of the Upper Helderberg, Hamilton, Portage and Chemung Groups. Van Benthuysen \& Sons, Albany.

Havlíček, V. 1971. Brachiopodes de l'Ordovicien du Maroc. Notes et Mémoires du Service Géologique du Maroc, 230, 1-135. 
Herranz Araújo, P., Gutiérrez-Marco, J.C., Pieren Pidal, A.P., Robardet, M., San José Lancha, M.A., Rábano, I. \& Sarmiento, G.N. 2003. The Ordovician succession from the western Iberian Ranges (NE Spain): a review with new data. INSUGEO, Serie Correlación Geológica, 17, 417-424.

Hertwig, R. 1895. Lehrbuch der Zoologie, 3rd edit. Fischer, Jena.

Hind, W. 1910. The lamellibranchs of the Silurian rocks of Girvan. Transactions of the Royal Society of Edinburgh, 47, 479-548.

Hisinger, W. 1831. Anteckningar i physik och geognosi under resor uti Sverige och Norrige. Femte Häfte. B.M. Bredberg, Stockholm.

Horný, R.J. 1962. New genera of Bohemian Lower Paleozoic Bellerophontina. Vestnik Ceského Geologického Ústavu, 37, 473-476.

Horný, R.J. 1963. Lower Paleozoic Bellerophontina (Gastropoda) of Bohemia. Ustredni ustav geologicky, Sbornik geologickych ved, Paleontologie, 2, 57-164.

Horný, R.J. 1965. On the systematical position of Cyrtolites Conrad, 1838 (Mollusca). Časopsis Národního muzea., oddíl př́rodovědný, 134, 8-10.

Horný, R.J. 1991. Shell morphology and muscle scars of Sinuitopsis neglecta Perner (Mollusca, Monoplacophora). Časopis Národního muzea v Praze, fada pfirodovedna, 157, 81-105.

Horný, R.J. 1996. Secondary shell deposits and presumed mode of life in Sinuites (Mollusca, Gastropoda). Acta Musei Nationalis Pragae, Series B, Historia Naturalis, 51, 89-103.

Horný, R.J. 1997a. Bucanopsina gen. n., a new bellerophontoidean gastropod with circumbilical muscle attachment areas from the Middle Ordovician of Bohemia. Věstník Ceskeho geologickeho ústavu, 72, 5-13.

Horný, R.J. 1997b. New, rare, and better recognized Ordovician Tergomya and Gastropoda (Mollusca) of Bohemia. Věstník Ústředního ústavu geologického, 72, 223-237. 
Horný, R.J. 1997c. Circumbilical retractor muscle attachment area in the Ordovician trilobed bellerophontoidean gastropod Tritonophon peeli sp. n. Věstník Ústředního ústavu geologického, 72, 333-338.

Horný, R.J. 1997d. Nonorios gen. n., a new platyceratid gastropod (Mollusca) from the Middle Ordovician of the Mediterranean Palaeoprovince. Časopis Národního muzea, Rada př́rodovědná, 166, 104.

Horný, R.J. 1997e. Ordovician tergomya and gastropoda (Mollusca) of the Anti-Atlas (Morocco). Acta Musei Nationalis Pragae, Series B, Natural History, 53, 37-78.

Horný, R.J. 1997f. Circumbilical retractor muscle attachment areas in the Upper Ordovician bellerophontoidean gastropod Grandostoma grande (Barrande in Perner, 1903). Časopis Národního muzea, Rada přirodovědná, 166, 99-103.

Horný, R.J. 1999a. Circumbilical retractor muscle attachment areas found in Tropidodiscus (Gastropoda, Bellerophontoidea). Journal of the Czech Geological Society, 44, 126-130.

Horný, R.J. 1999b. Gastropod, paragastropod and tergomyan biostratigraphy of the Ordovician of Bohemia. Acta Universitatis Carolinae, Geologica, 43, 397-400.

Horný, R.J. 2000. Tachloconcha gen. n. and Spirina Kayser, 1889, two additional Lower Palaeozoic gastropods with preserved retractor muscle attachment scars. Věstník Českého geologického ústavu, 75, 415-426.

Horný, R.J. 2002. Ordovician Tergomya and isostrophic Gastropoda (Mollusca) of Bohemia: Types and referred specimens in the collections of the National Museum, Prague, Czech Republic. Acta Musei Nationalis Pragae, Series B, Natural History, 57, 69-102.

Horný, R.J. \& Peel, J.S. 1996. Carcassonnella, a new Lower Ordovician bellerophontiform mollusc with dorsally located retractor muscle attachments (Class Tergomya). Věstník Českého geologického ústavu, 71, 305-331. 
Horný, R.J., Vizcaïno, D. 1995. Thoralispira, a new Lower Ordovician cyrtonellid genus (Mollusca, Tergomya) from the Montagne Noire, southern France. Věstník Českého geologického ústavu, 70, 25-41.

Hyatt, A. 1884. Genera of fossil cephalopods. Proceedings of the Boston Society of Natural History, 22, 253-338.

Isberg, O. 1934. Studien über Lamellibranchiaten des Leptaenakalkes in Dalarna. Ohlssons, Lund.

Jell, P.A., Burret, C.F., Stait, B. \& Yochelson, E.L. 1984. The Early Ordovician bellerophontoid Peelerophon oehlerti (Bergeron) from Argentina, Australia and Thailand. Alcheringa, 8, 169-176.

Khalfin, L. 1958. Plastinchatozhabernye mollyuski ordovika Chu Iliiskikhgor. Trudy Geologicheskiy Institut (Moskva), 9, 139-193 [in Russian].

Knight, J.B. 1934. The gastropods of the Saint Louis, Missouri, Pennsylvanian outlier. VII. the Euomphalidae and Platyceratidae. Journal of Paleontology 8, 139-166.

Knight, J.B. 1941. Paleozoic Gastropod Genotypes. Geological Society of America, Special Papers, 32, 1-510.

Knight, J.B. 1945. New Genera of the Bellerophontacea. Journal of Paleontology, 19, 333340.

Kobayashi, T. 1934. The Cambro-Ordovician formations and faunas of South Chosen; paleontology, part I: Middle Ordovician Faunas. Journal of the Faculty of Science, Imperial University of Tokyo, Section II, Geology, Mineralogy, Geography, Seismology, 3, 335-519.

Kobayashi, T. 1959. Some Ordovician fossils from the Thailand-Malayan borderland. Japanese Journal of Geology and Geography, 29, 223-231. 
Koken, E. 1896. Die Leitfossilien. Ein Handbuch fur den Unterricht und fur das Bestimmen von Versteinerungen. Leipzig, Chr. Herm. Tauchnitz.

Koken, E. 1897. Die Gastropoden des baltischen Untersilurs. Bulletin de l'Académie Impériale des Sciences de St.-Pétersbourg, Série 5, 7, 97-214.

Koken, E. \& Perner, J. 1925. Die Gastropoden den baltischen Untersilurs. Memoires de l'Academie des Sciences de Russie, Serie 8, Classe physico-mathematique, 37, 1-326.

Krasilova, I.N. 1970. In: Rozman, Kh.S., Ivanova, V.A., Krasilova, I.N. \& Modzalevskaja, E.A. (eds) Upper Ordovician Biostratigraphy of the USSR NE. Trudy, Geologicheskiy Institut, Akademiya Nauk SSSR, Moscow, 205, 168-187, 287-288 [in Russian].

Krasilova, I.N. 1979. Dvustvorchatyye Mollyuski mangazeyskogo, Dolborskogo I Ketskogo gorizontov. In: Rozman, Kh.S., Krasilova, I.N., Stukalina, T.A. \& Sytova, V.A. (eds) Fauna Ordovika Srednei Sibiri. Trudy, Geologicheskiy Institut, Akademiya Nauk SSSR, Moscow, 330, 79-130 [in Russian].

Krríž, J. 1969. Genus Butovicella Křŕž, 1965 in the Silurian of Bohemia (Bivalvia). Sborník geologických věd, Palaeontologie, 10, 105-139.

Kř́žž, J. 1999. Bivalvia dominated communities of Bohemian type from the Silurian and Lower Devonian carbonate facies. In: Boucot, A.J. \& Lawson, J.D. (eds) Final report, project Ecostratigraphy. Paleocommunities: A case study from the Silurian and Lower Devonian. Cambridge University Press, Cambridge, 229-252.

Kř́ž, J. 2005. Telychian (Llandovery, Silurian) bivalves from Spain. Paleontology, 48, 455477.

Krríž, J. \& Steinová, M. 2009. Uppermost Ordovician bivalves from the Prague Basin (Hirnantian, Perunica, Bohemia). Bulletin of Geosciences, 84, 409-436. 
Kröger, B. 2013. Cambrian-Ordovician cephalopod palaeogeography and diversity. In: Harper, D.A.T. \& Servais, T. (eds) Early Palaeozoic Biogeography and Palaeogeography. Geological Society London Memoirs, 38, 429-428.

Kröger, B. \& Zhang, Y. 2009. Pulsed cephalopod diversification during the Ordovician. Palaeogeography, Palaeoclimatology, Palaeoecology, 273, 174-183.

Kuhn, O. 1940. Paläozoologie in Tabellen. Fischer, Jena.

Landing, E. \& Kröger, B. 2012. Cephalopod ancestry and ecology of the hyolith "Allatheca" degeeri s.l. in the Cambrian Evolutionary Radiation. Palaeogeography, Palaeoclimatology, Palaeoecology, 353, 21-30.

Lefebvre, B. 2007. Early Palaeozoic palaeobiogeography and palaeoecology of stylophoran echinoderms. Palaeogeography, Palaeoclimatology, Palaeoecology, 245, 156-199.

Linné, C. 1758. Systema naturae per regna tria naturae, secundum classes, ordines, genera, species, cum characteribus, differentiis, synonymis, locis. Editio decima, reformata. Salvisu, Holmiae.

Loi, A., Ghienne, J.-F., Dabard, M.P., Paris, F., Botquelen, A., Christ, N., Elaouad-Debbaj, Z., Gorini, A., Vidal, M., Videt, B. \& Destombes, J. 2010. The Late Ordovician glacio-eustatic record from a high-latitude storm-dominated shelf succession: The Bou Ingarf section (Anti-Atlas, Southern Morocco). Palaeogeography, Palaeoclimatology, Palaeoecology, 296, 332-358.

Matthews, S.C. 1973. Notes on open nomenclature and on synonymy lists. Palaeontology, 16, $713-719$.

Marek, L. 1963. Bellerophontid gastropods in the Kosov Beds (Ordovician) of Bohemia. Věstnik Ústředního ústavu geologického, 38, 277-280.

Marek, J. 1999. Ordovician cephalopods of the Prague Basin: a review. Acta Universitatis Carolinae, Geologica, 43, 413-416. 
McAlester, A.L. 1968. Type species of Paleozoic nuculoid bivalve genera. Memoir of the Geological Society of America, 105, 1-143.

McAlester, A.L. 1969. Palaeotaxodonta (Bivalvia). In: Moore, R.C. (ed.) Treatise on Invertebrate Paleontology. Part N, Mollusca 6, Bivalvia. Geological Society of America \& University of Kansas Press, Boulder \& Lawrence, N227-N243.

McCoy, F. 1852. Description of the British Palaeozoic fossils in the Geological Museum of the University of Cambridge. Parker \& Son, London.

Mergl, M. 1983. New brachiopods (Cambrian-Ordovician) from Algeria and Morocco (Mediterranean Province). Časopis pro Mineralogii a Geologii, 28, 337-347.

Miller, S.A. 1877. The American Palaeozoic fossils, a catalogue of the genera and species. Published by the author, Cincinnati, Ohio.

Miller, S.A. 1889. North American geology and palaeontology for the use of amateurs, students and scientists. Western Methodist Book Concern, Cincinnati.

Monteserín López, V., Navarro Juli, J.J., Palero, F., Pascual Muñoz, H., Hernández Samaniego, A., Dabrio, C., Gutiérrez-Marco, J.C., Sarmiento, G., Pieren Pidal, A., Gorgues, R., Lillo Ramos, J., López Sopeña, F. \& Carreras Suárez, F. 2016. Hoja 837 (Viso del Marqués), Mapa Geológico de España a escala 1:50.000, 2 a Serie Magna. IGME, Ministerio de Economía y Competitividad, Madrid.

Neumayr, M. 1884. Zur Morphologie der Bivalvenschlosses. Sitzungsberichte der Kaiserlichen Akademie der Wissenschaften, Mathematisch-naturwissenschaftliche Klasse, 88, 385-419.

Neumayr, M. 1891. Beiträge zu einer morphologischen Eintheilung der Bivalven. Denkschriften der Kaiserlichen Akademie der Wissenschaften, Mathematischnaturwissenschaftliche Klasse, 58, 701-801. 
2355

2356

2357

2358

2359

2360

2361

2362

2363

2364

2365

2366

2367

2368

2369

2370

2371

2372

2373

2374

2375

2376

2377

2378

2379

Nevesskaya, L.A., Scarlato, O.A., Starobogatov, Y.I. \& Eberzin, A.G. 1971. Novye predstavleniia o sisteme dvustvorchatykh molliuskov. Paleontologicheskii Zhurnal, 1971, 3-20 [in Russian].

Novack-Gottshall, P.M. \& Miller, A.I. 2003. Comparative geographic and environmental diversity dynamics of gastropods and bivalves during the Ordovician Radiation. Paleobiology, 29, 576-604.

Oehlert, D.P. 1888. Descriptions de quelques espèces devoniennes du département de la Mayenne. Bulletin de la Societe d'Etudes Scientifiques d' Angers, 1887, 65-120.

Öpik, A. 1953. Lower Silurian fossils from the 'Illaenus Band' Heathcote, Victoria. Memoirs of the geolological Survey of Victoria, 19, 1-42.

Özdikmen, H. 2008. New family and Genus names, Wademidae nom. nov. and Wadema nom. nov., for Georginidae and Georgina Wade, 1977 (Mollusca: Cephalopoda). Munis Entomology \& Zoology, 3, 594-595.

Paul, H. 1939. Die Muscheln der Magdeburger Kulmgrauwacke. Abhandlungen und Berichte aus dem Museum für Naturkunde und Vorgeschichte und dem Naturwissenschaftlichen Verein in Magdeburg, 7, 165-181.

Peel, J.S. 1974. Systematics, ontogeny and functional morphology of Silurian trilobed bellerophontacean gastropods. Bulletin of the geological Society of Denmark, 23, 231-264.

Peel, J.S. 1975. New Silurian gastropods from Nova Scotia and Britain. Canadian Journal of Earth Sciences, 12, 1524-1533.

Peel, J.S. 1984. Autecology of Silurian gastropods and monoplacophorans. Special Papers in Palaeontology, 32, 165-182.

Peel, J.S. 1991. The Class Tergomya and Helcionelloida, and early molluscan evolution. Grønlands Geologiske Undersøgelse, Bulletin, 161, 11-65.

Peel, J.S. 2006. Scaphopodization in Palaeozoic molluscs. Palaeontology, 49, 1357-1364. 
Pelseneer, P. 1889. Sur la classification phylogénétique de pélécypods. Bulletin Scientifique de la France et de la Belgique, 20 [= sér. 3, 2] (1-4), 27-52.

Perner, J. 1903. Systéme Silurien du centre de la Bohême par Joachim Barrande. lère partie: Recherches Paléontologiques, Vol IV, Gastéropodes, Tome 1, Texte (Patellidae et Bellerophontidae) et Planches 1-89. C. Bellmann, Prague.

Perner, J. 1907. Systéme Silurien du centre de la Bohême par Joachim Barrande. 1ère partie: Recherches Paléontologiques, Vol IV, Gastéropodes, Tome 2, Texte et Planches 90-175. C. Bellmann, Prague.

Perner, J. 1911. Systéme Silurien du centre de la Bohême par Joachim Barrande. lère partie: Recherches Paléontologiques, Vol IV, Gastéropodes, Tome 3, Texte et Planches 176-247. C. Bellmann, Prague.

Pfab, L. 1934. Revision der Taxodonta des böhmischen Silurs. Palaeontographica, Abteilung $A, \mathbf{8 0}, 195-253$.

Pitcher, B.L. 1939. The Upper Valentian Gastropod Fauna of Shropshire. Annals and Magazine of Natural History Series 11, 4, 82-132.

Pojeta, J. 1966. North American Ambonychiidae (Pelecypoda). Palaeontographica Americana, 5, 129-241.

Pojeta, J. 1971. Review of Ordovician Pelecypods. United States Geological Survey Professional Papers, 685, 1-46.

Pojeta, J. 1978. The origin and early taxonomic diversification of Pelecypods. Royal Society of London Philosophical Transactions, B 284, 225-246.

Polechová, M. 2013. Bivalves from the Middle Ordovician Šárka Formation (Prague Basin, Czech Republic). Bulletin of Geosciences, 88, 427-461.

Polechová, M. 2016. The bivalve fauna from the Fezouata Formation (Lower Ordovician) of Morocco and its significance for palaeobiogeography, palaeoecology and early 
diversification of bivalves. Palaeogeography, Palaeoecology, Palaeoclimatology, 460, $155-169$.

Portlock, J.E. 1843. Report on the Geology of the County Londonderry and of parts of Tyrone and Fermanagh, Milliken, Dublin.

Rábano, I., Gutiérrez-Marco, J.C. \& García-Bellido, D.C. 2014. A remarkable illaenid trilobite from the Middle Ordovician of Morocco. Bulletin of Geosciences, 89, 365-374.

Reed, F.RC. 1920. A monograph of the British Ordovician and Silurian Bellerophontacea. Part I. Palaeontographical Society Monograph for 1918, 1-48. Universidade do Porto, 4, 121-126.

2428

Reed, F.R.C. 1944. Some new Ordovician lamellibranchs from Girvan. Annals and Magazine of Natural History, Series 11, 76, 209-215.

Reed, F.R.C. 1952. Revision of certain Ordovician fossils from County Tyrone. Proceedings of the Royal Irish Academy. Section B: Biological, Geological, and Chemical Science, 55, 29-136.

Reich, M., Sprinkle, J., Lefebvre, B., Rössner, G. \& Zamora, S. 2017. The first Ordovician cyclocystoid (Echinodermata) from Gondwana and its morphology, paleoecology, taphonomy, and paleogeography. Journal of Paleontology, 91, 735-754.

Rollins, H.B. \& Batten, R.L. 1968. A sinus-bearing monoplacophoran and its role in the classification of primitive molluscs. Palaeontology, 11, 132-140.

Romão, J.M., Gutiérrez-Marco, J.C., Rábano, I., Oliveira, J.T. \& Guedes, A.M. 1995. A Formação de Cabeço do Peão (Ordovícico Superior) no Sinforma Amêndoa-Carvoeiro (SW da ZCI) e sua correlação estratigráfica na província mediterrânica. Memórias do Museu e Laboratório Mineralógico e Geológico da Faculdade de Ciências da

Saemann, L. 1852. Über die Nautiliden. Palaeontographica, 3, 121-167. 
Sá, A.A. 2006. Biostratigrafia do Ordovícico do nordeste de Portugal (Zona Centro-Ibérica): estado actual do conhecimento. In: Mirão, J. \& Balbino, A. (eds) Livro de Resumos do VII Congresso Nacional de Geologia, Évora, 2, 617-620.

Sá, A.A. 2008. Moluscos del Ordovícico de la región de Trás-os-Montes (Zona Centroibérica, NE de Portugal). Coloquios de Paleontologia, 58, 41-72.

Sánchez, T.M. 1990. Bivalvos del Ordovícico medio-tardío de la Precordillera de San Jaun (Argentina). Ameghiniana, 27, 251-261.

Sánchez, T.M. 1999. New Late Ordovician (Early Caradoc) bivalves from the Sierra de Villicum (Argentine Precordillera). Journal of Paleontology, 73, 66-76.

Scarlato, O.A. \& Starobogatov, Y.I. 1979. Osnovye cherty evoliutsii i sistema klassa Bivalvia [General evolutionary patterns and the system of the Class Bivalvia]. In: Starobogatov, Y.I. (ed.) Morfologiia, Sistematika i Filogeniia Molliuskov. Akademiia Nauuk SSSR, Trudy Zoologicheskogo Instituta, 80, 5-38 [In Russian]. For English translation, see K.J. Boss \& M.K. Jacobson (1985), Museum of Comparative Zoology, Harvard University, Department of Mollusks. Special Occasional Publication, 5, 1-67.

Schallreuter, R. 1970. Alter und Heimat der Backsteinkalkgeschiebe. Hercynia (Neue Folge), 6, 285-305.

Sinicyna, I.N. 1979. Nekotoryye pozdneordovikskne dvustrozchatye mollyuski Kazakhstana. Voprosy Paleontologii, 8, 72-83, 134-137 [in Russian].

Sowerby, J. de C. 1839. In: Murchison, R.I. The Silurian System etc., Part II, Organic remains, 579-768. Murray, London.

Stait, B.A. \& Burrett, C.F. 1984. Ordovician nautiloid faunas of central and southern Thailand. Geological Magazine, 121, 115-124.

Stanley, S.M. 1970. Relation of shell form to life habits of the Bivalvia (Mollusca). Geological Society of America Memoir, 125, 1-296. 
Stewart, S. 2012. Distribution and palaeoecology of Ordovician bivalves and gastropods from Girvan, SW Scotland. Earth and Environmental Science Transactions, 102, 145-158.

Sutton, M.D., Briggs, D.E.G., Siveter, D.J. \& Siveter, D.J. 2006. Fossilized soft tissues in a Silurian platyceratid gastropod. Proceedings of the Royal Society B: Biological Sciences, 273, 1039-1044.

Teichert, C. 1933. Der Bau der actinoceroiden Cephalopoden. Palaeontographica Abteilung A, 77, 111-230.

Termier, G. \& Termier, H. 1950. Paleontologic marocaine. Tome II, Invertebrés de I'Ere primaire, fascicule 3. Mollusques, Notes et Mémoires du Service géologique du Maroc, 78, $1-247$.

Toni, R.T. 1975. Upper Ordovician bivalves from the Oslo region. Norsk Geologisk Tidsskrift, 55, 135-156.

Troedsson, G.T. 1918. Om Skånes brachiopodskiffer. Lunds Universitets Årsskrift Ny Följd, 2, 1-104.

Tromelin, G. \& Lebesconte, P. 1875. Note sur quelques fossiles des grès siluriens de SaintGermaine-sur Ille etc. Compte rendu du Congres de l'Association Francaise pour l'Avancemente des Sciences en 1875, 1876, 683-687.

Tunnicliff, S.P. 1982. A revision of late Ordovician bivalves from Pomeroy, Co. Tyrone, Ireland. Palaeontology, 25, 43-88.

Tunnicliff, S.P. 1987. Caradocian bivalve molluscs from Wales. Palaeontology, 30, 677-690.

Ulrich, E.O. 1892. New Lamellibranchiata. American Geologist, 10, 96-104.

Ulrich, E.O. \& Scofield, W.H. 1894. The Lower Silurian Lamellibranchiata of Minnesota. In: Ulrich, E.O., Scofield, W.H., Clarke, J.M. \& Winchell, N.H. (eds) Final Report of the Geological and Natural History Survey of Minnesota, vol. 3, part 2, The Geology of Minnesota, Paleontology. Minneapolis, 475-628. 
Ulrich, E.O. \& Scofield, W.H. 1897. The Lower Silurian Gastropoda of Minnesota. Geology of Minnesota. Final Report of the Geological Survey of Minnesota, 3, 813-1081.

Villas, E., Vizcaïno, D., Álvaro, J.J., Destombes, J. \& Vennin, E. 2006. Biostratigraphic control of the latest-Ordovician glaciogenic unconformity in Alnif (Eastern Anti-Atlas, Morocco), based on brachiopods. Geobios, 39, 727-737.

Vinassa de Regny, P. 1927. Fossili ordoviciani sardi. Atti della Reale Accademia Nazionale dei Lincei. Memoire della Classe di Scienze Fisiche, Matematiche e Naturali, Series, 6, 2, $1-60$.

Vinn, O., Wilson, M.A., Zatoń, M. \& Toom, U. 2014. The trace fossil Arachnostega in the Ordovician of Estonia (Baltica). Palaeontologia Electronica, 17.3.40A, 1-9.

Vinther, J., Parry, L., Briggs, D.E.G. \& Van Roy, P. 2017. Ancestral morphology of crowngroup molluscs revealed by a new Ordovician stem aculiferan. Nature, 542, 471-474

Vinther, J., Jell, P., Kampouris, G., Carney, R., Racicot, R.A. \& Briggs, D.E.G. 2012. The origin of multiplacophorans - convergent evolution in aculiferan molluscs. Palaeontology, 55, 1007-1019.

Wade, M. 1977. Georginidae, new family of actinoceratoid cephalopods, Ordovician, Australia. Memoir of the Queensland Museum, 18, 1-15.

Wade, M. 1988. Nautiloids and their descendants: cephalopod classifcation in 1986. Memoir of the New Mexico Bureau of Mines and Mineral Resources, 44, 15-25.

Wagner, P.J. 1995. Stratigraphic tests of cladistic hypotheses. Paleobiology, 21, 153-178.

Wagner, P.J. 1999. Phylogenetics of Ordovician-Silurian Lophospiridae (Gastropoda: Murchisoniina): the importance of stratigraphic data. American Malacological Bulletin, 15, 1-31.

Wagner, P.J. 2002. Phylogenetic relationships of the earliest anisostrophically coiled gastropods. Smithsonian Contributions to Paleobiology, 88, 1-152. 
Wahlman, G.P. 1992. Middle and Upper Ordovician Symmetrical Univalved Mollusks (Monoplacophora and Bellerophontina) of the Cincinnati Arch Region. US Geological Survey Professional Papers, 1066-O, 1-213.

Webby, B.D., Paris, F., Droser, M. \& Percival, I. 2004. The Great Ordovician Biodiversification Event. Columbia University Press, New York.

Wenz, W. 1938-1944. Gastropoda. In: Schindewolf, O.H. (ed.) Handbuch der Paläozoologie. Band 6. Gebrüder Borntraeger, Berlin, 1-1506.

Whitfield, R.P. 1886. Notice of geological investigations along the eastern shore of Lake Champlain, conducted by Prof. H. M. Seely and Pres. Ezra Brainerd, of Middlebury College, with descriptions of the new fossils discovered. Bulletin of the American Museum of Natural History, 1, 8, 293-345.

Yochelson, E.L. 1963. The Middle Ordovician of the Oslo Region, Norway. 15. Monoplacophora and Gastropoda. Norsk geologisk tidsskrift, 46, 133-213.

Yochelson, E.L. 1964. Modestospira, a New Ordovician Gastropod. Journal of Paleontology, 38, 891-898.

Zamora, S., Rahman, I.A. \& Ausich, W.I. 2015. Palaeogeographic implications of a new iocrinid crinoid (Disparida) from the Ordovician (Darriwilian) of Morocco. Peer J, 3, e1450, 1-19.

Zittel, K.A. \& Eastman, C.R. 1913. Textbook of Palaeontology (2nd ed.) 1. Macmillan, London. 


\section{Figure captions}

Fig. 1. (a) Map of Morocco showing inset of enlarged area in (b). (b) Simplified geological map of the Moroccan Anti-Atlas, showing the distribution of Ordovician rocks and localities. The numbered localities refer to tergomyan and gastropod material, while E2 refers to the Erfoud 2 locality. Modified from Horný (1997e) and Álvaro et al. (this volume).

Fig. 2. Range and distribution of molluscs discussed herein. The stratigraphy is based on Álvaro et al. (this volume).

Fig. 3. (a) Pie diagram illustrating the composition of the Early Ordovician bivalve fauna from Morocco, Polechová (2016). (b) Pie diagram illustrating the composition of the Late Ordovician bivalve fauna from Morocco.

Fig. 4. Sinuitopsis neglecta Barrande in Perner, 1903 from the Lower Ktaoua Formation. (a) \& (b) NM S7574, right lateral and dorsal views showing fine sculpture (latex cast).

Destombes locality 1778. (c) NM S2664, cross-section and growth lines on umbilical wall. (d) NM S2573, right lateral view of mature specimen showing overall morphology. Destombes locality 88. (e)-(h) NM S2572, dorsal, left lateral, posterior, and detail views of internal mould showing muscle impression (arrows). Destombes locality 88 . Scale bars for (a)$(\mathbf{c})=5 \mathrm{~mm},(\mathbf{d})-(\mathbf{g})=10 \mathrm{~mm},(\mathbf{h})=1 \mathrm{~mm}$.

Fig. 5. Atlantophon maider Horný, 1997e from the Lower Ktaoua Formation. (a)-(e) Holotype (NM S2673). Left lateral, anterior, dorsal, posterior oblique, and detailed views respectively. Destombes locality 882 . Scale bars $=5 \mathrm{~mm}$. 
Fig. 6. Sinuites destombesi Horný, 1997e from the Upper Ktaoua Formation. (a)-(d) Holotype specimen (NM S2560) showing characteristic shape and ornamentation. Destombes locality 1624. (e) One of the largest specimens (NM S2569), showing sculpture and subinductural vallum (arrow) (see also Fig. 6b \& 6d). Destombes locality 1651. (f) Anterior view of large specimen (NM S2562) showing the shape of the median apertural sinus. Upper arrow points to sinus apex. Lower arrow points to edge of lateral shield. Destombes locality 1624. Scale bars $=10 \mathrm{~mm}$.

Fig. 7. Sinuites destombesi Horný, 1997e from the Upper Ktaoua Formation. Details of ornamentation. (a) NM S2566, median sinus with comarginal ribs only. Destombes locality 1080. (b) NM S2569, sub-dorsum of left flank of last whorl with commarginal ribs and fainter spiral lirae (see Fig. 5e for left lateral view of specimen). Destombes locality 1651. (c) NM S2560 (Holotype), median sinus with comarginal ribs and spiral lirae. Destombes locality1624. (d) NM S2569 showing subinducturala deposits (si) on the lower left side of the last whorl (see Fig. 5e for left lateral view of specimen). Destombes locality 1651. (e) NM S2560 (Holotype), showing labroumbilical depression (lud) and labroumbilical ridge (lur). Destombes locality 1624. (f) NM S2563 showing subinductural deposits (si). Destombes locality 1624 . Scale bars $=1 \mathrm{~mm}$.

Fig. 8. Sinuites destombesi Horný, 1997e from the Upper Ktaoua Formation. Cross section of specimen MGM-6963X. Locality Jbel Bou Ingarf 'South'. Scale bar $=10 \mathrm{~mm}$.

Fig. 9. Tritonophon peeli Horný, 1997d from the Lower Ktaoua Formation. NM S2668, right side and posterior views illustrating ornamentation and the high median lobe. Destombes locality 399 . Scale bars $=1 \mathrm{~mm}$. 
Fig. 10. Tritonophon grandis sp. nov., from the Lower Second Bani Formation. (a)-(e)

2577

2578

2579

2580

2581

2582

2583

2584

2585

2586

2587

2588

2589

2590

2591

2592

2593

2594

2595

2596

2597

2598

2599

Holotype (MGM-6967X), right lateral, left lateral, posterior, dorsal, and anterior views respectively. (f) Posteror view of paratype (MGM-6968X). (g) \& (h) Posterior and right lateral views of paratype (MGM-6969X). Locality Aït Isioul 'south'. Scale bar in (a) is same for $(\mathbf{a})-(\mathbf{e})$. Scale bars $=5 \mathrm{~mm}$.

Fig. 11. Bucanopsina calypso (Perner, 1903) from the Lower Ktaoua Formation. (a) \& (b) Specimen NM S2659, dorsally compressed. Dorsal view and detail of median sinus respectively. (b) is a latex cast. Destombes locality 1640. (c) \& (d) Right lateral and posterior view of well-preserved, uncompressed specimen (NM S2660). Latex cast. Destombes locality 1778. Scale bars for $(\mathbf{a})=10 \mathrm{~mm},(\mathbf{b})=1 \mathrm{~mm},(\mathbf{c}) \&(\mathbf{d})=5 \mathrm{~mm}$.

Fig. 12. Nonorios pater (Barrande in Perner, 1903) from the Lower Ktaoua Formation. (a) \& (b) Specimen NM S2631, dorsal and lateral oblique views of typical internal mould.

Destombes locality 1270. (c) \& (d) Specimen NM S2632, latex cast of umbilicus and dorsal view of same specimen showing ornamentation. Destombes locality 1276 . Scale bars $=10$ $\mathrm{mm}$.

Fig. 13. Radvanospira antiquata (Perner, 1903) from the Lower Ktaoua Formation. (a) \& (b) Specimen NM S2702, apertural and lateral views of internal mould. Destombes locality 1305. (c) Specimen NM S2627, dorsal view of steinkern. Destombes locality 1305. (d) \& (e) Dorsal and lateral oblique views of steinkern (NM S2698). Destombes locality 88. (f) \& (g) Dorsal and lateral oblique views showing ornamentation (NM S2628). Destombes locality 1315. Scale bars $=10 \mathrm{~mm}$. 
Fig. 14. Radvanospira antiquata (Perner, 1903) from the Lower Ktaoua Formation. (a) \& (b)

2602

2603 Specimen NM S2700, dorsal view of internal mould and latex cast of the umbilicus of the same showing fine growth lines. Destombes locality 88. (c)-(e) NM S2626, lateral, lateral oblique, and dorsal views of well-preserved specimen showing partially preserved ornamentation. Destombes locality 1313. (f)-(h) NM S2629, apertural, lateral, and ventral views of small specimen. Destombes locality 1315. (i) NM S2701, lateral view of large internal mould. Scale bars $=5 \mathrm{~mm}$.

Fig. 15. Radvanospira baniensis sp. nov. from the Lower Second Bani Formation at the locality Aït Isioul 'south'. (a)-(f) Holotype (MGM-6977X), apertural, dorsal, lateral, ventral, lateral, and ventral oblique views respectively. (g)-(i) Internal mould (MGM-6978X), apertural, lateral and dorsal views respectively. Specimen was sectioned (see Fig. 16). Scale bars $=10 \mathrm{~mm}$.

Fig. 16. Radvanospira baniensis sp. nov. from the Lower Second Bani Formation at the locality Aït Isioul ‘south’. Cross section of specimen MGM-6978X (see also Fig. 15(g)-(i)). Scale bar $=10 \mathrm{~mm}$.

Fig. 17. Deaechospira amouguerana (Horný, 1997b) from the Upper Tiouririne Formation. (a)-(h) Holotype (NM S2654) in various views. Destombes locality 585. (g) \& (h) are latex cast showing details of the peripheral band. Arrows in (a) \& (g) points to a repaired injury. Scale bars in $(\mathbf{a})-(\mathbf{f})=5 \mathrm{~mm},(\mathbf{g}) \&(\mathbf{h})=1 \mathrm{~mm}$ 
Fig. 18. Deaechospira amouguerana (Horný, 1997b) from the Lower Ktaoua Formation. (a)(c) NM S2656, latex cast of base of mature specimen showing inner margin. Destombes locality 1778. (d)-(f) NM S2655, lateral, ventral, and apertural view showing ornamentation and shell repair (arrows). Destombes locality 585. (g)-(i) NM S2686 Lateral, ventral oblique and detail views of specimen showing the apertural sinus. Destombes locality 86. (j) NM S2685, detail of peripheral band. Destombes locality 86. (k) NM S2684, internal mould with some shell, showing the course of the peripheral band. Destombes locality 86 . Scale bars for (a) $-(\mathbf{h}) \&(\mathbf{k})=5 \mathrm{~mm},(\mathbf{i}) \&(\mathbf{j})=1 \mathrm{~mm}$.

Fig. 19. Deaechospira amouguerana (Horný, 1997b) from the Lower Ktaoua Formation. (a)(e) NM S2657, latex cast of juvenile specimen showing ornamentation and peripheral band. Arrow in (b) points to shell repair. Destombes locality 1778 . Scale bars $=1 \mathrm{~mm}$.

Fig. 20. Deaechospira sp. from the Upper Tiouririne Formation. Destombes locality 134. (a)(f) NM S2689, various views of specimen with partial shell preserved. S = sinus. Arrow in (d) points to muscle scar. (e) \& (f) are latex cast from external mould, showing apertural sinus and peripheral band respectively. (g)-(i) NM S2687, lateral, dorsal and detail of partial specimen. Scale bars of $(\mathbf{a})-(\mathbf{e})=5 \mathrm{~mm},(\mathbf{f})-(\mathbf{i})=1 \mathrm{~mm}$.

Fig. 21. Allossospira debganensis (Horný, 1997e) from the Upper Ktaoua Formation. (a)-(i) NM S2644, holotype, various views showing morphological details. Arrows in (e) show the transistion from a flat peripheral band with sharp upper margin to protruding periperhal band adaperturally. Destombes locality 1132. Scale bars for $(\mathbf{a})-(\mathbf{f}) \&(\mathbf{h})=5 \mathrm{~mm},(\mathbf{g}) \&(\mathbf{i})=1$ $\mathrm{mm}$. 
2649

2650

2651

2652

2653

2654

2655

2656

2657

2658

2659

2660

2661

2662

2663

2664

2665

2666

2667

2668

2669

2670

2671

2672

2673

Fig. 22. Allossospira debganensis (Horný, 1997e) from the Upper Ktaoua Formation at the locality Jbel Bou Ingarf 'South'. (a) \& (b) MGM-6979X, large specimen showing development of spire and peripheral band. Arrows in (a) point to the different convexity of the left and right sides of the whorl. Arrows in (b) point to shell repair. (c) MGM-6980X showing protruding peripheral band. (d) MGM-6981X showing several shell layers. (e) MGM-6982X, dorsal view of small specimen. Arrow points to possible impression of the protoconch. (f) MGM-6983X, detail of un-bordered peripheral band. (g) \& (h) MGM-6984X, lateral and ventral views of shell respectively, showing the turn of the growth lines on the lower whorl surface and base. Arrows point to shell repair. All specimens are silicon casts. Scale bars for $(\mathbf{a})-(\mathbf{d}),(\mathbf{g}) \&(\mathbf{h})=10 \mathrm{~mm},(\mathbf{e})=5 \mathrm{~mm},(\mathbf{f})=1 \mathrm{~mm}$.

Fig. 23. Allossospira debganensis (Horný, 1997e) from the Upper Ktaoua Formation at the locality Jbel Bou Ingarf 'South'. (a) \& (b) MGM-6985X-1, small specimen showing development of whorl curvature, peripheral band and ornamentation. (c) MGM-6985X-2, apertural view of small specimen occurring with MGM-6985X-1. Both specimens are silicon casts. Scale bars $=1 \mathrm{~mm}$.

Fig. 24. Allossospira debganensis (Horný, 1997e) from the Upper Ktaoua Formation at the locality Jbel Bou Ingarf 'South'. (a) MGM-6986X, steinker in place in the external mould. (b) MGM-6987, cross section showing the development of the whorls. Scale bars $=10 \mathrm{~mm}$.

Fig. 25. Lophospira latilabra sp. nov. From the Upper Ktaoua Formation at the locality Jbel Bou Ingarf 'South'. (a)-(d), (f)-(h), (i) \& (k) MGM-6992X, holotype. Silicon casts of both halves of the external mould. (e) \& (j) MGM-6993X, paratype. Apertural view and detail of spire showing possible protoconch. Scale bars $=5 \mathrm{~mm}$. 
2675 Fig. 26. (a), (d), (e), (g) \& (j) Myoplusia sp. (a), (j) MGM-6853X, right valve, dorsolateral

2676

2677

2678

2679

2680

2681

2682

2683

2684

2685

2686

2687

2688

2689

2690

2691

2692

2693

2694

2695

2696

2697

2698

view. (j) Lateral view. (d) MGM-6852X, right valve, lateral view. (e) FSL 550117, left valve, lateral view. (g) MGM-6851X, left valve, lateral view. (b), (c) \&(k)-(q) Praenucula pojetai sp. nov. (b) \& (m) MGM-6846X, paratype, left valve, external mould, lateral view. (m) Paratype, left valve, internal mould, lateral view. (c) FSL 550161, right valve, lateral view. (k) \& (n) MGM-6843X, articulated specimen. (k) Dorsolateral view. (n) Dorsal view. (l) FSL 550118, right valve, lateral view. (o)-(q) MGM-6845X, holotype, left valve. (o) Lateral view. (p) Dorsal view. (q) Dorsolateral view. (f), (h) \& (i) Sluha kosoviensis (Barrande, 1881d). (f) \& (h) MGM-6847X, left valve. (f) Dorsolateral view. (h) Lateral view. (i) FSL 550162, external mould, lateral view. Scale bars $=5 \mathrm{~mm}$.

Fig. 27. (a), (e) \& (h) Dceruska sp. (a) MGM-6861X, left valve, lateral view. (e) \& (h) MGM-6842X, articulated specimen. (e) Lateral view. (h) Dorsal view. (b), (c), (i)-(k) \& (l) Cyrtodonta sp. (b) MGM-6863X, left valve, lateral view. (c) MGM-6859X, right valve, lateral view. (i) \& (k) MGM-6869X, articulated specimen. (i) Right valve, lateral view. (k) Dorsal view. (j) \& (l) MGM-6868X, articulated specimen. (j) Dorsal view. (l) Left valve, lateral view. (d) \& (m)-(o) Nuculites sp. (d) MGM-6860X, right valve, lateral view. (m)-(o) MGM-6862X, left valve. (m) Part of the external mould. (n) Dorsolateral view. (o) Lateral view. (f) \& (g) Cleionychia transversa (Portlock, 1843). MGM-6841X, left valve. (f) Detail of the anterior part with anterior adductor muscle scar. (g) Lateral view. Scale bars for (b)-(d) $=20 \mathrm{~mm},(\mathbf{a}) \&(\mathbf{e})-(\mathbf{m})=10 \mathrm{~mm}$.

Fig. 28. Angular measurements (angles alpha, beta, gamma) used in describing Ambonychiids (after Pojeta 1966). 
Fig. 29. (a), (c) \& (d)-(h) Cleionychia prisca (Portlock, 1843). (a) MGM-6875X, left valve, lateral view. (c) MGM-6856X, right valve, lateral view. (d)-(h), MGM-6864X, two specimens in life position. (d) Two articulated specimens, lateral view. (e) One articulated specimen (MGM-6864X a) showing hinge line. (f) One articulated specimen, posterior view. (g) Anterior view with beaks into the substrate, brachiopods and bryozoans. (h) Lateral view on two articulated specimens. (b) \& (j) Ambonychia sp., MGM-6866X, articulated specimen. (b) Dorsal view with prominent escutcheon. (j) Left valve, lateral view. (i) Ambonychia aff. magna Isberg, 1934. MGM-6858X, left valve, dorsal view. Scale bars $=10 \mathrm{~mm}$.

Fig. 30. (a), (d) \& (e)-(k) Modiolopsis sp. (a) MGM-6873X, left valve, lateral view (d) MGM-6857X, left valve, lateral view (e) MGM-6874X, right valve, lateral view. (f) MGM6871X, left valve, lateral view (g) MGM-6867X, left valve, lateral view. (h) \& (j) MGM6872X, right valve. (h) Lateral view. (j) Detail of the right valve, lateral view. (i) \& (k) MGM-6870X, right valve. (i) Lateral view. (k) Detail of the right valve, lateral view. (b) Pseudarca? sp., FSL 550155, left valve, lateral view. (c) Phestia? sp., FSL 550115, right valve, lateral view. Scale bars for $(\mathbf{c}) \&(\mathbf{g})=5 \mathrm{~mm},(\mathbf{a}),(\mathbf{b}),(\mathbf{d})-(\mathbf{f}) \&(\mathbf{h})-(\mathbf{k})=10 \mathrm{~mm}$.

Fig. 31. Actinocerids of the Upper Ktaoua Formation, Katian Stage, Morocco. (a) Wadema tattai sp. nov., specimen AA.ABT.OS 38, holotype. Naturally weathered median section. Note the thin siphuncular engrafts (arrow) and lamellar annuli, and note also the bryozoan overgrowth (left side). (b) Ormoceratidae gen. et sp. indet., specimen MGM-7014X, natural cut of internal mold, with massive remains of siphuncular annuli. Scale bars $=10 \mathrm{~mm}$.

Fig. 32. Late Ordovician cephalopods of Morocco. (a) \& (b) Tafadnatoceras tiouririnense 
gen. et sp. nov. from the Upper Tiouririne Formation, Katian; (a) MGM-7009X; (b) MGM7005X, holotype. (c) \& (d) Endoceratidae gen. et sp. indet. from the Taddrist Formation. (c) MGM-6997X, adoral view; (d) MGM-7001X, lateral view of internal mold of siphuncle. (e) Wadema sp., MGM-7013X, adoral view of internal mold. Scale bars for (a) \& (c)-(e) $=10$ $\mathrm{mm},(\mathbf{b})=5 \mathrm{~mm}$.

Fig. 33. Interpretation of septal neck, siphuncular tube structures. (a) Tafadnatoceras tiouririnense gen et sp. nov., holotype. (b) Paradnatoceras tubiforme Chen \& Liu, 1974, NIGP 15395-15653, holotype. Camera lucida drawing from median polished sections, not to scale. Black lines, septa; stippled lines, connecting ring; grey areas, siphuncular deposits. Endocameral deposits omitted.

Fig. 34. Polished median sections of siphuncle and septal neck details Tafadnatoceras tiouririnense gen et sp. nov. from the Upper Tiouririne Formation, Katian. (a) MGM-7003X, adoral part of specimen with barrel-shaped siphuncular segments. (b) MGM-7009X, part of section with of adnate barrel-shaped siphuncular segments; (c) same specimen as in (a), adapical part with nearly tubular siphuncular segments; (d) MGM-7005X, holotype, with stacked parietal siphuncular deposits, which form continuous lining, note also heavy endocameral deposits. Scale bars $=3 \mathrm{~mm}$. 


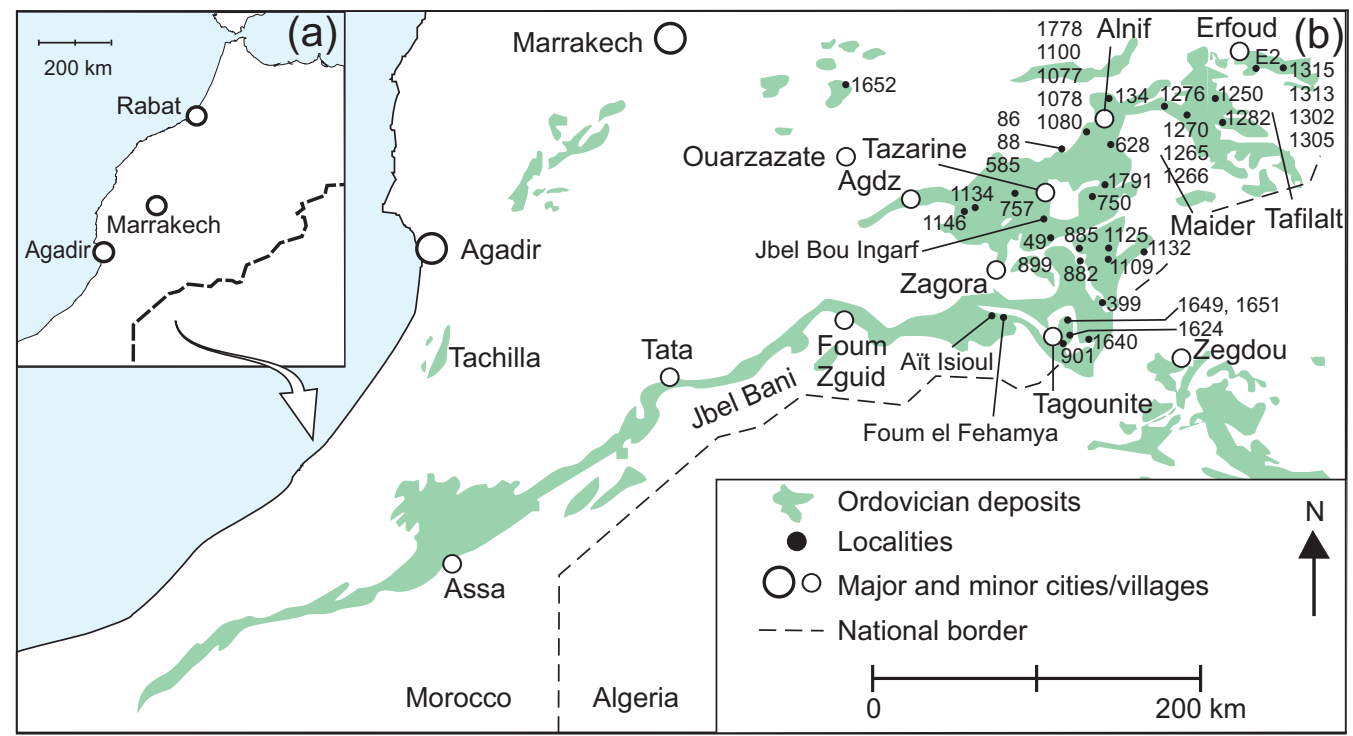




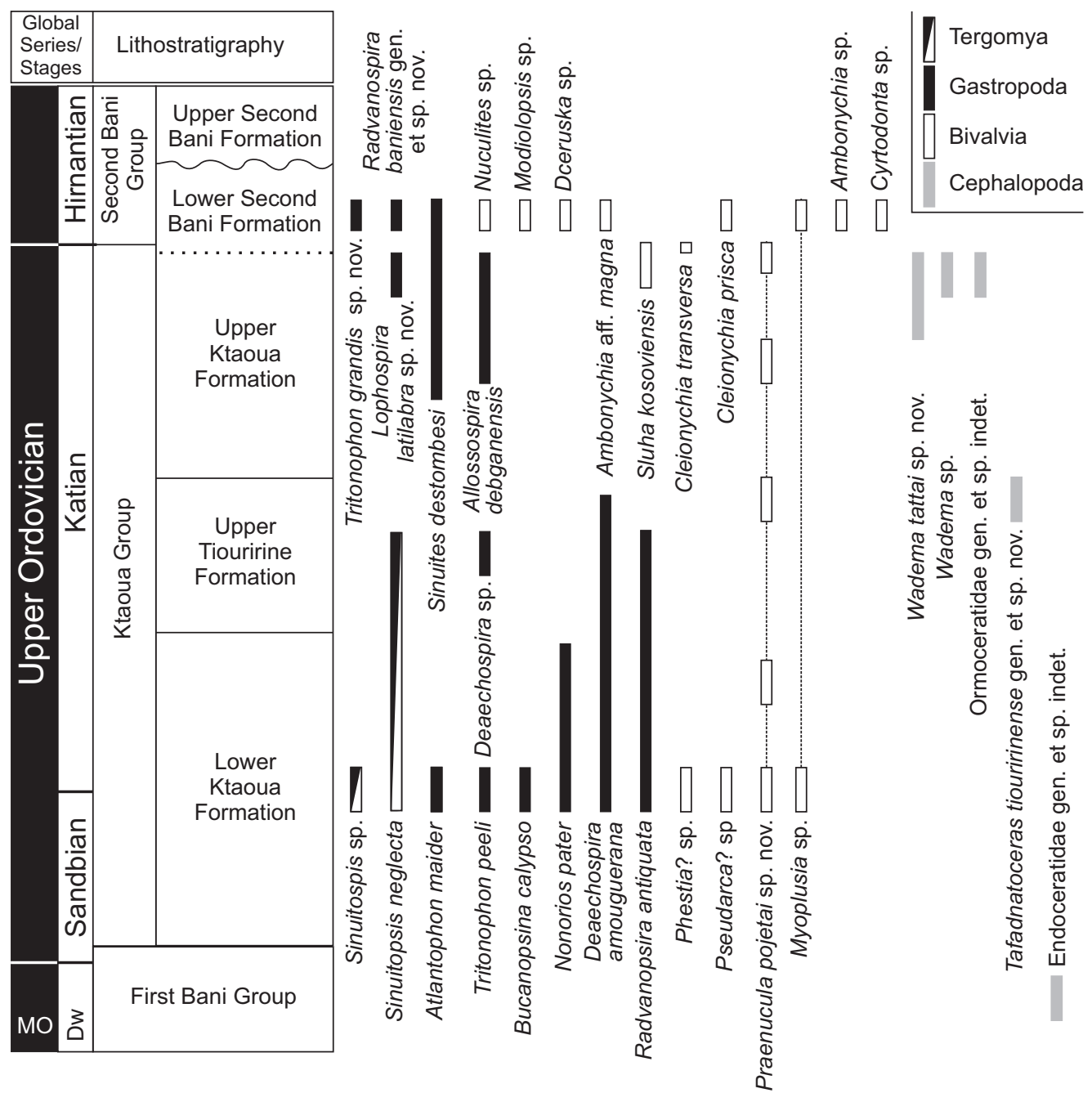


Fig. 2

(a)

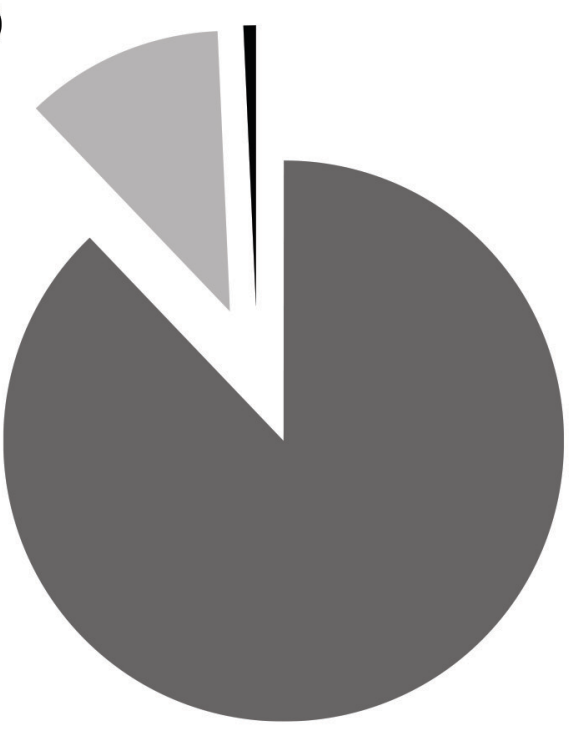

heteroconchs $88 \%, 123$

$$
\text { specimens }
$$

protobranchs, $11 \%, 16$ specimens

pteriomorphs, $1 \%, 1$ specimen

(b)

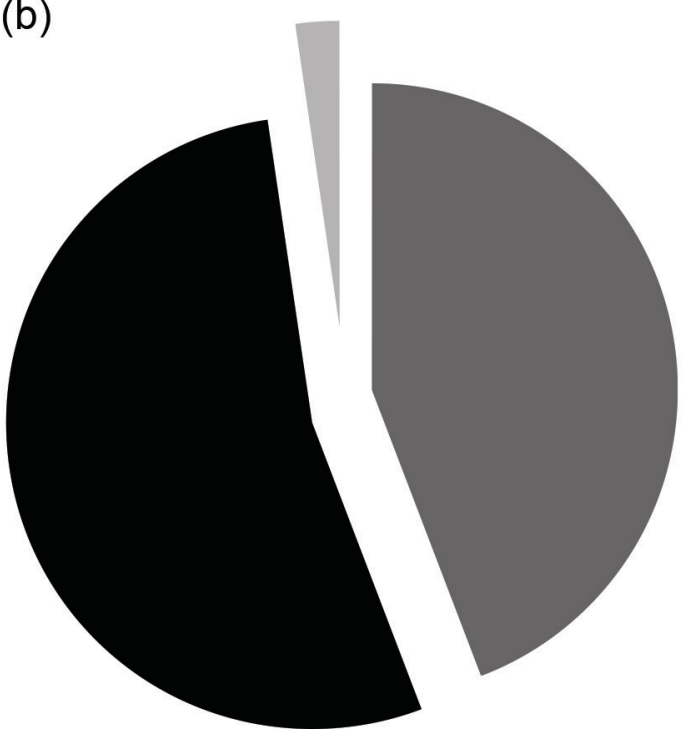

protobranchs, $44 \%, 19$ specimens

pteriomorphs, 53\%, 22 specimens

heteroconchs, $3 \%, 1$ specimen 
Figure-04.psd @ 41,5\% (Gray/8) *
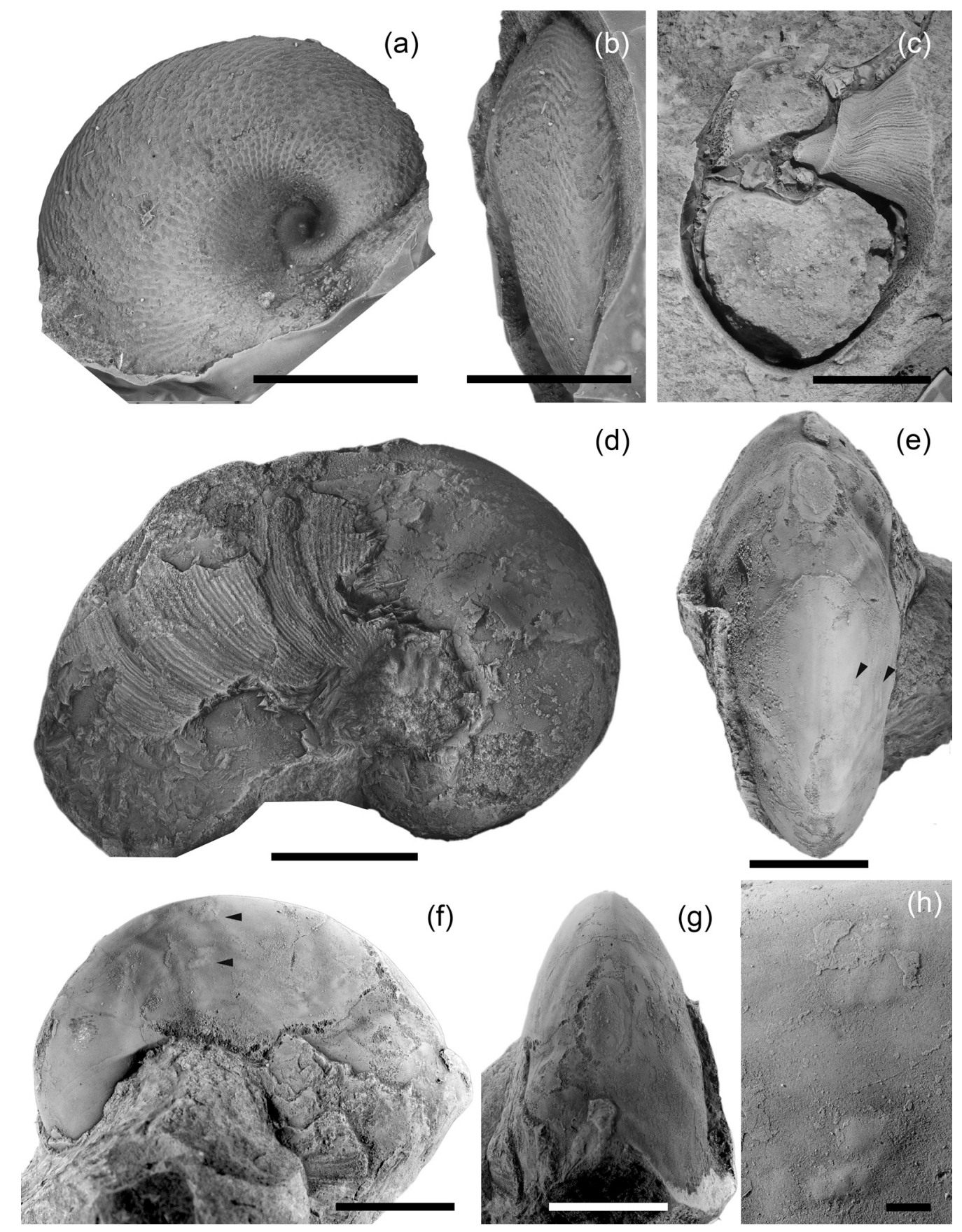
Figure-05.psd @ 66,7\% (Gray/8) *

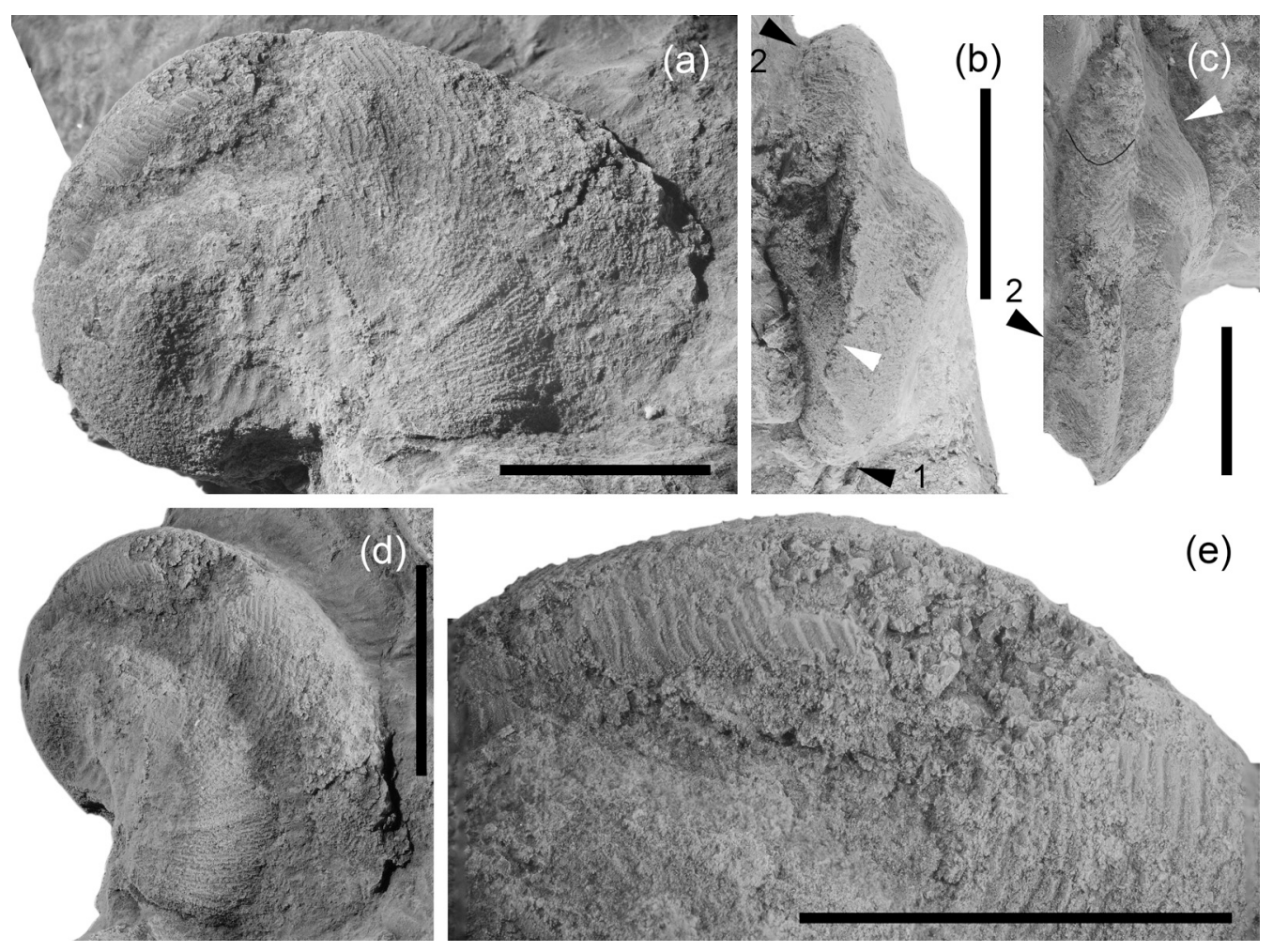


Figure-06.psd @ 33,3\% (Gray/8) *

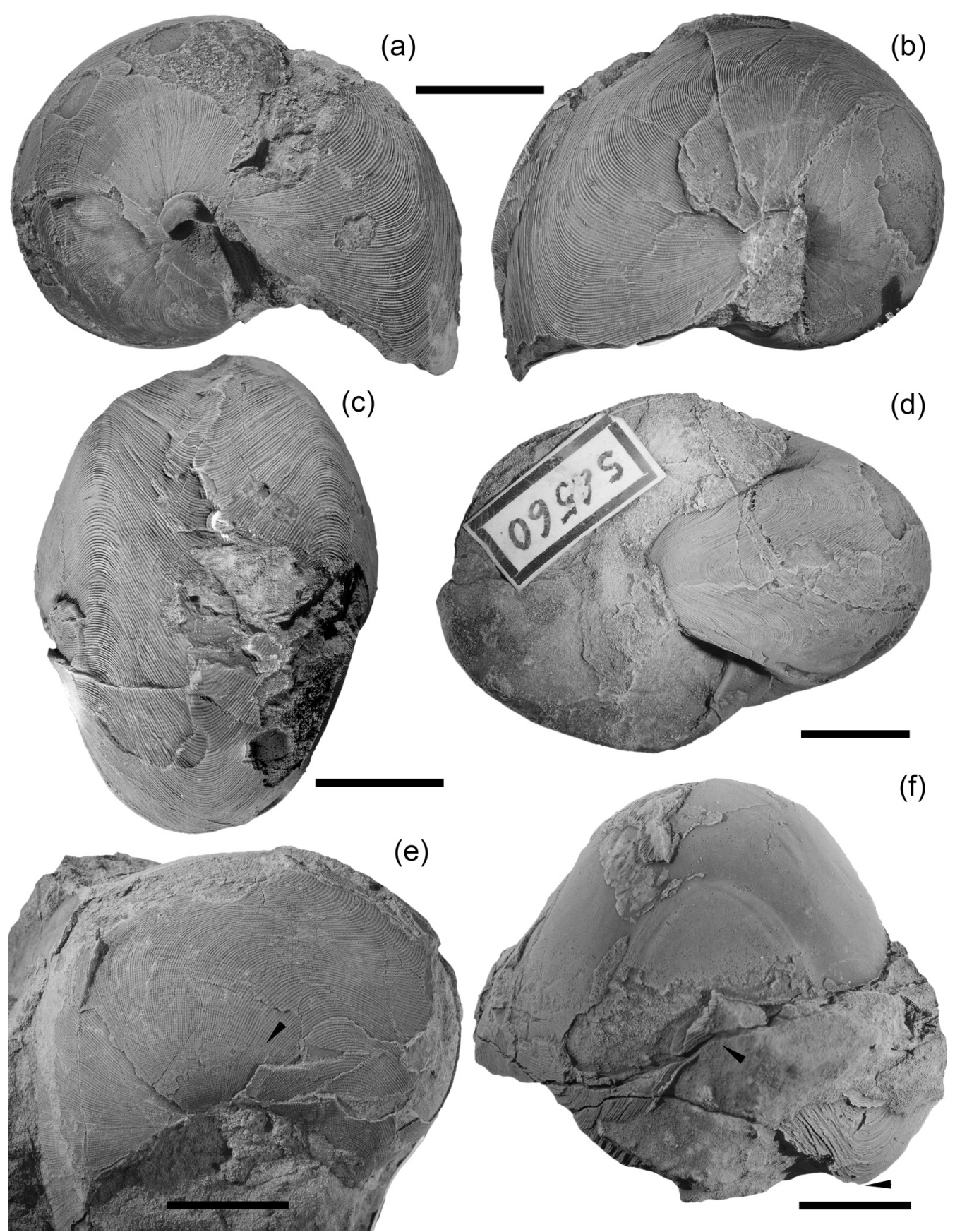


Figure-07.psd @ 33,3\% (Gray/8) *
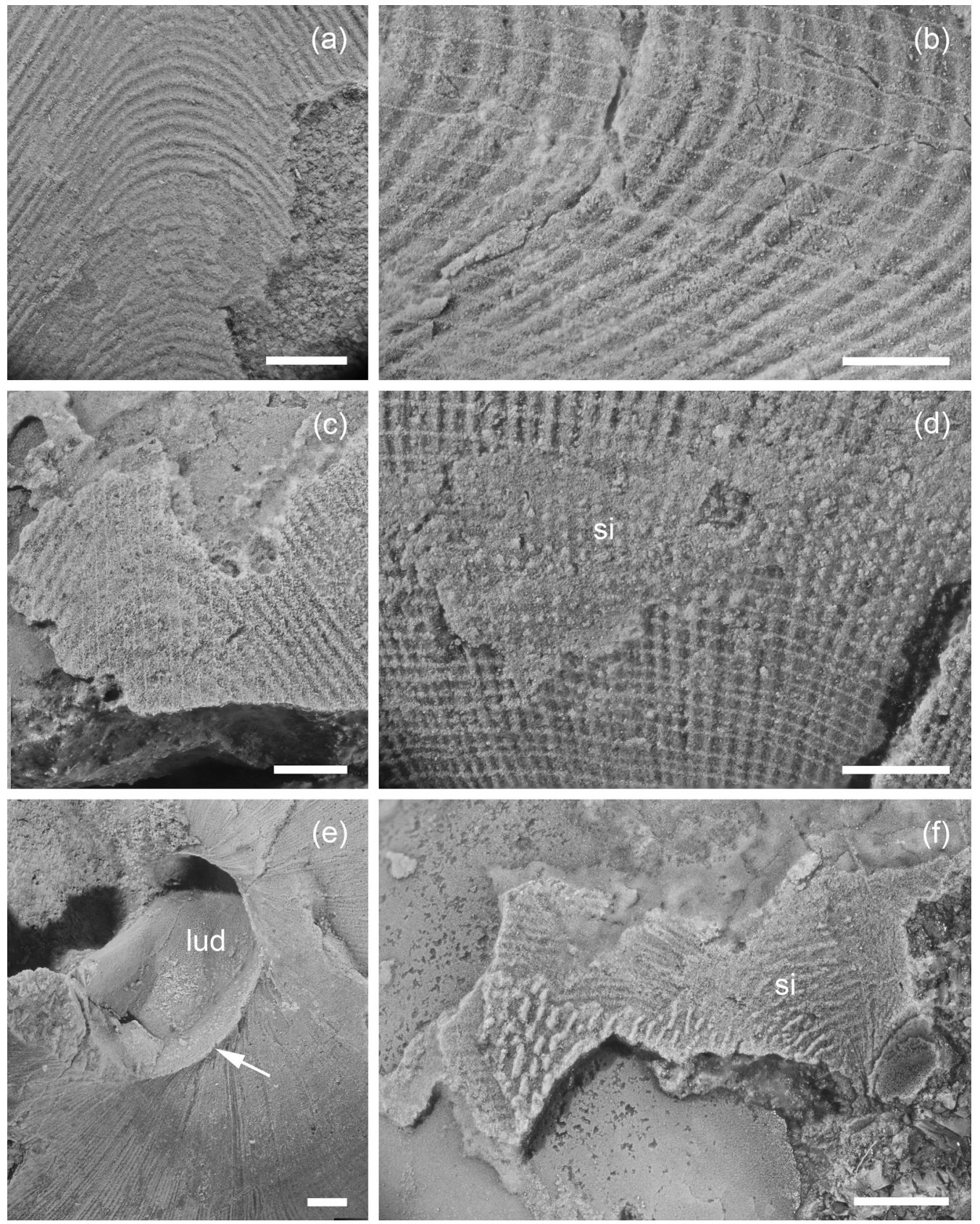


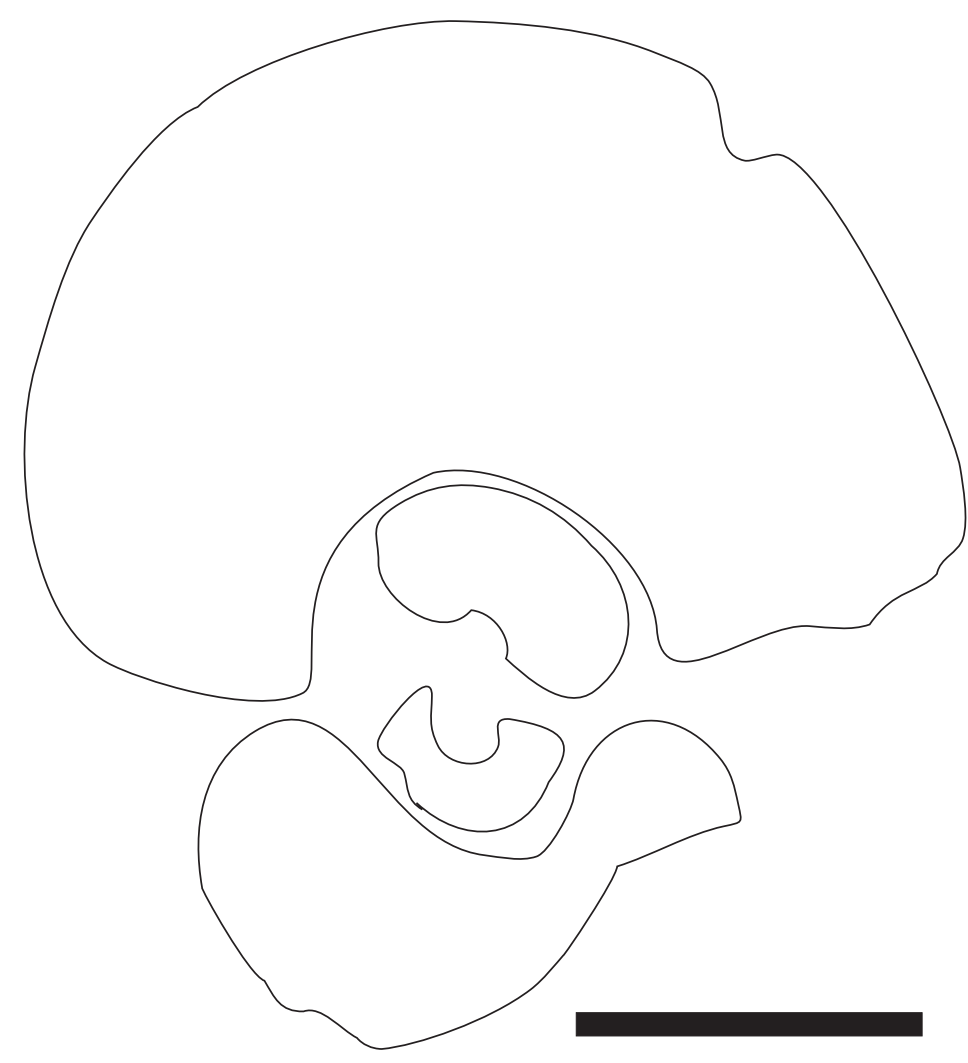


Figure-09.psd @ 100\% (RGB/8) *

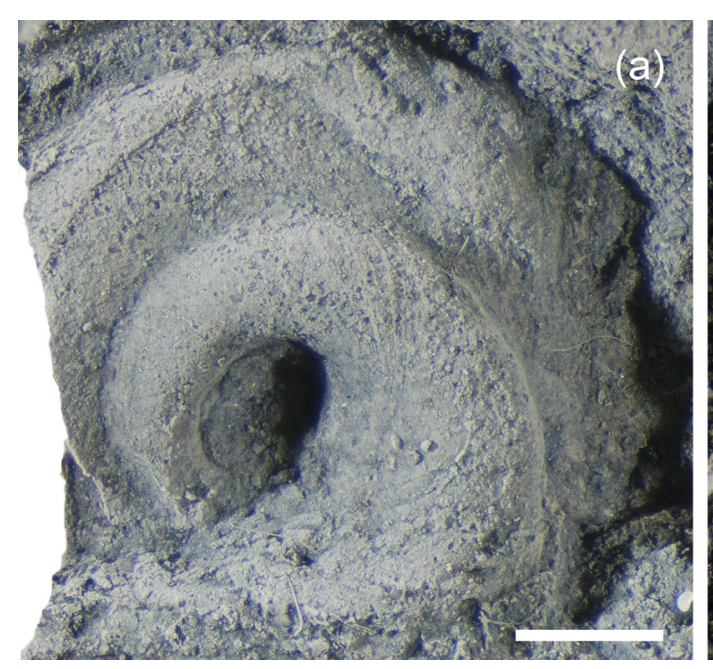

(b)

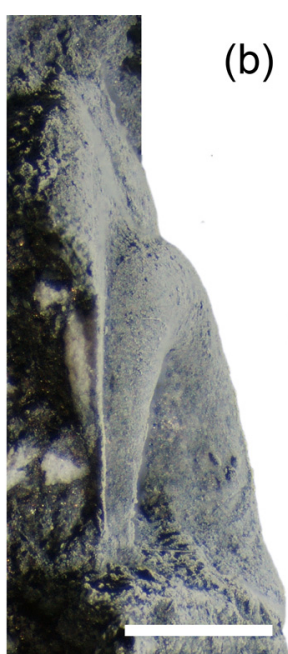


Figure-10.psd @ 142\% (Gray/8) *

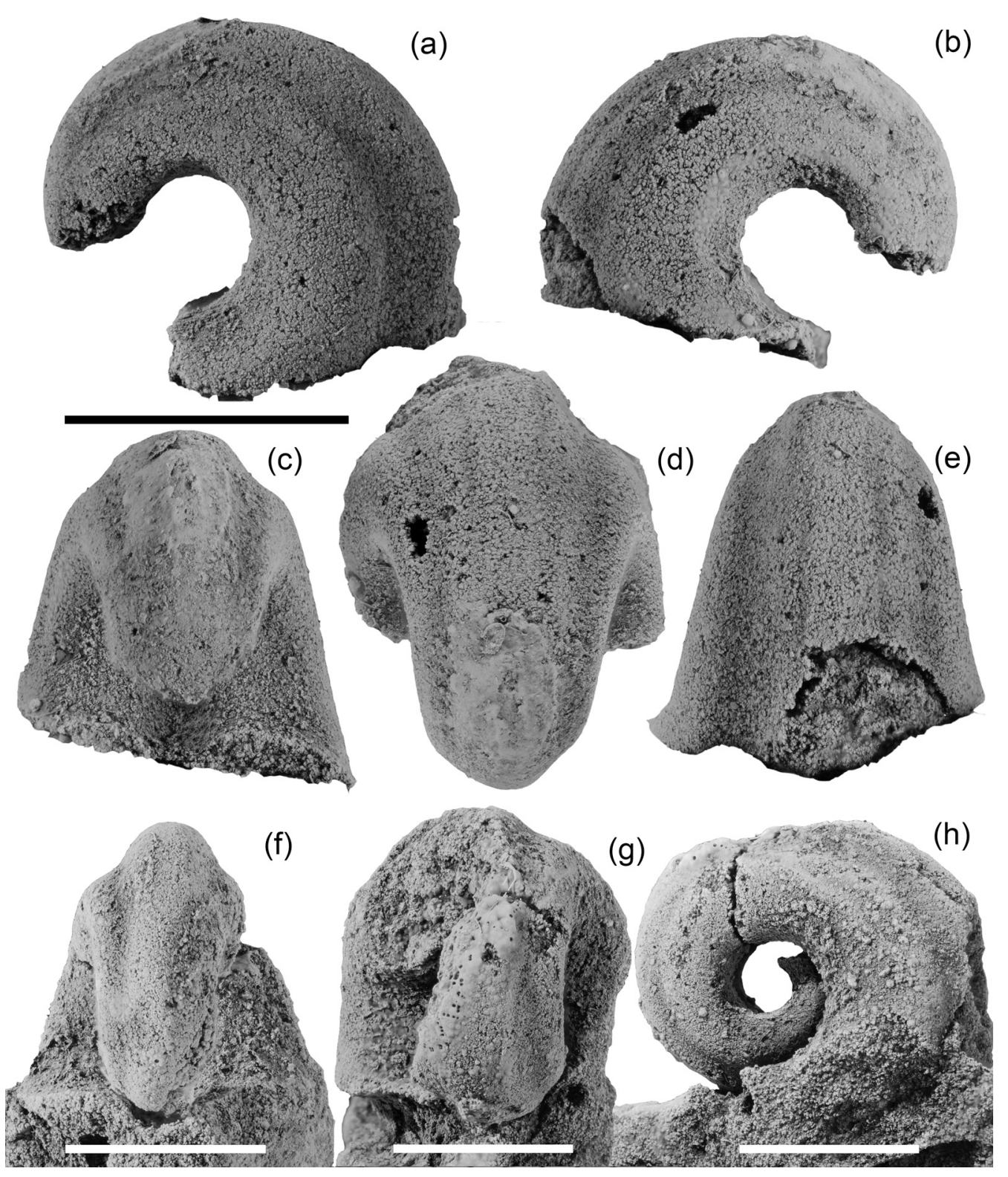


Figure-11.psd @ 50\% (Gray/8)*
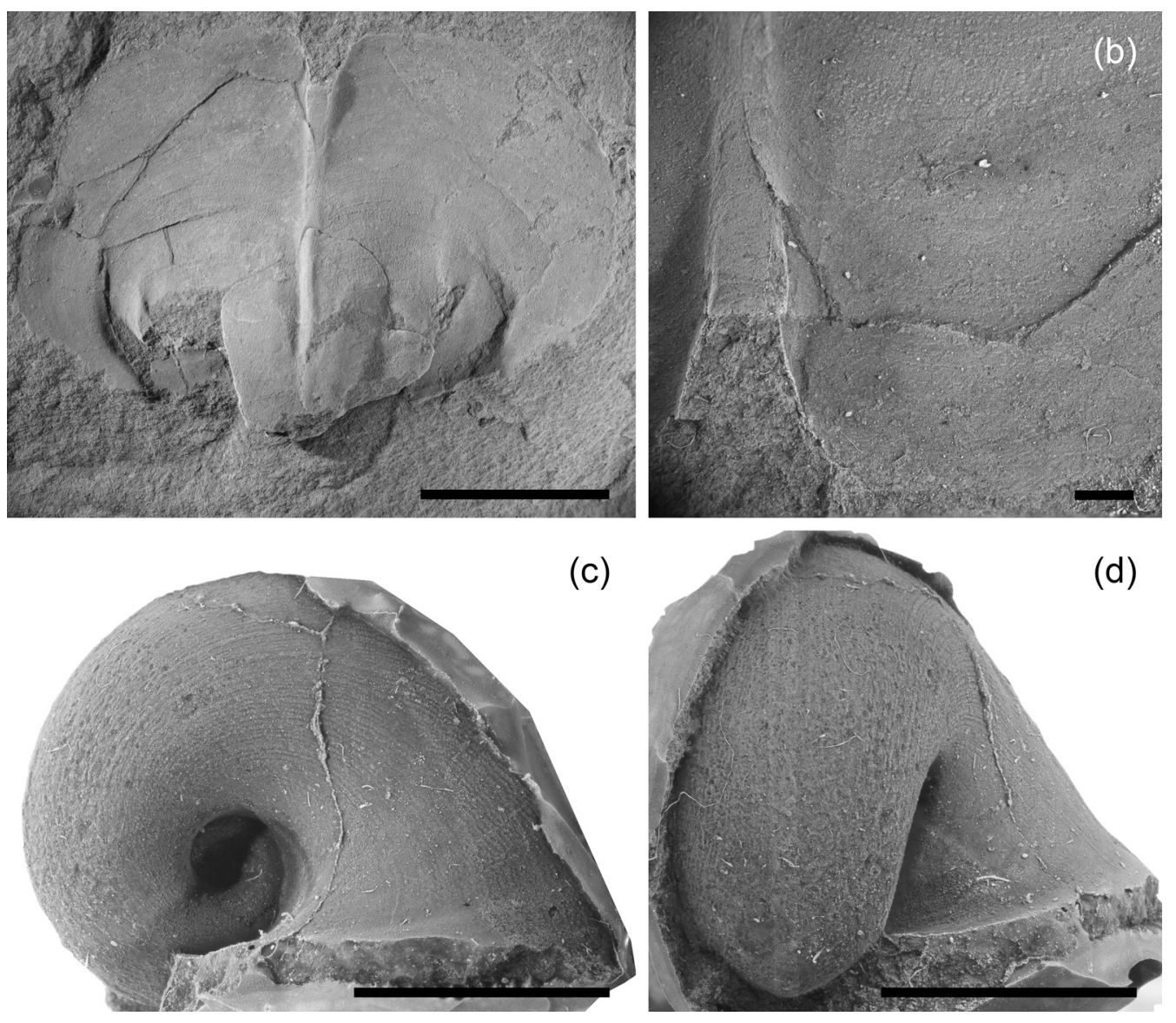
Figure-12.psd @ 62,4\% (Gray/8) *

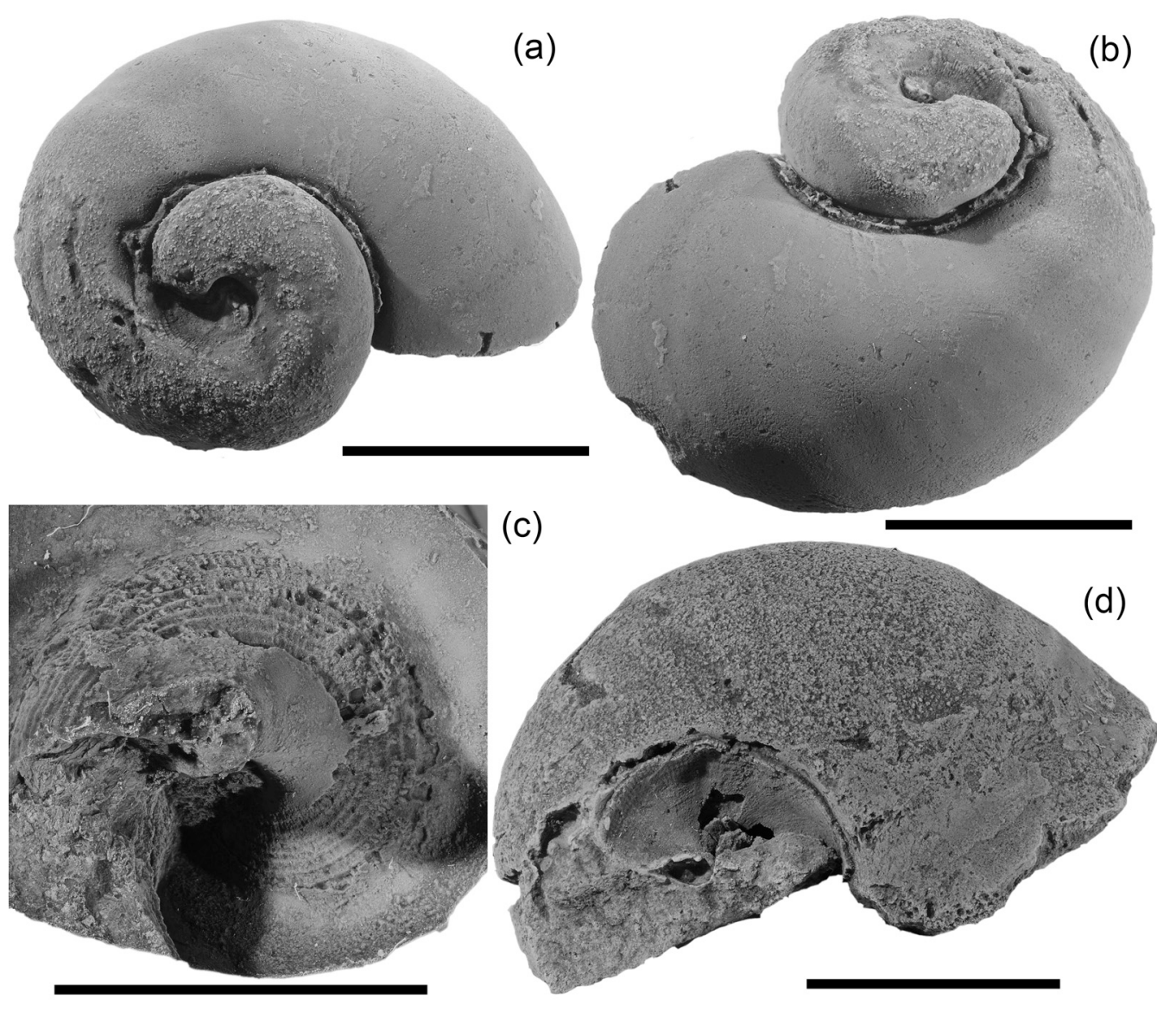


Figure-13.psd @ 33,3\% (Gray/8) *

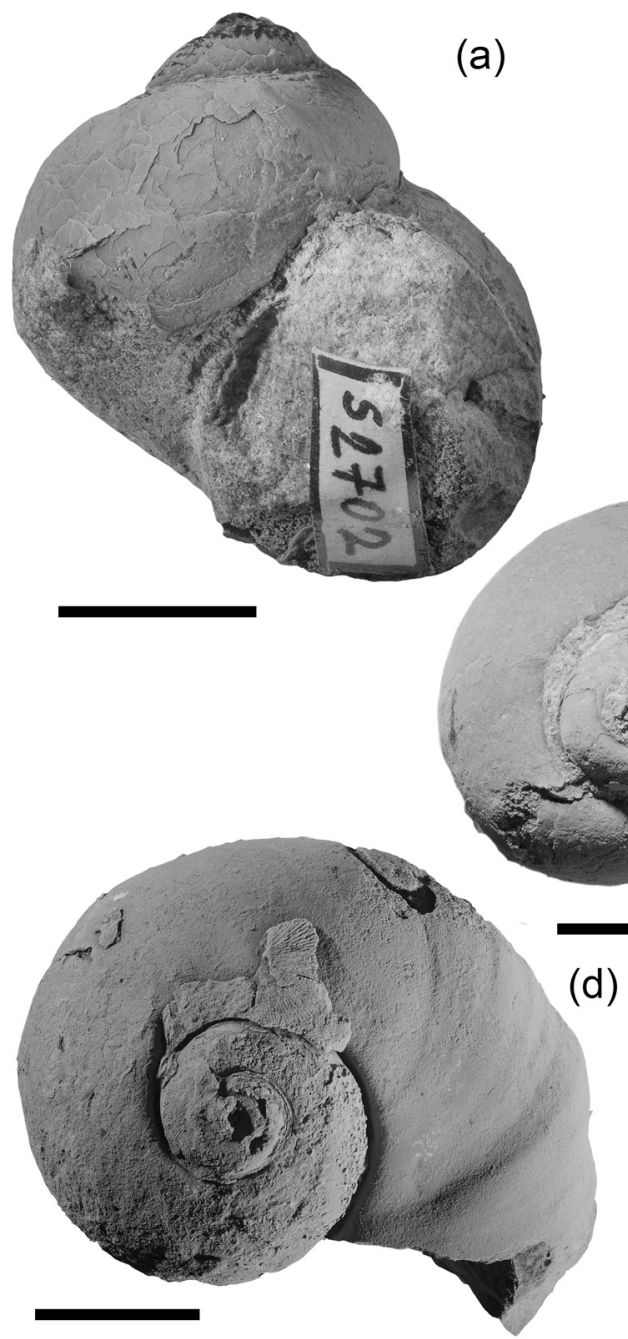

(c)

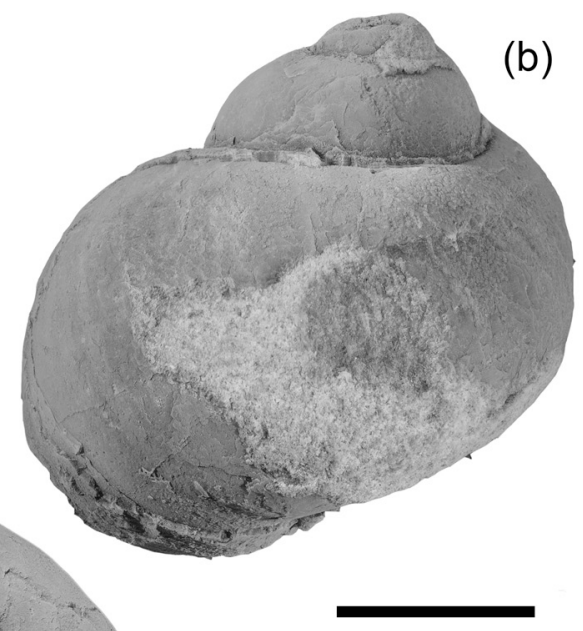

(b)

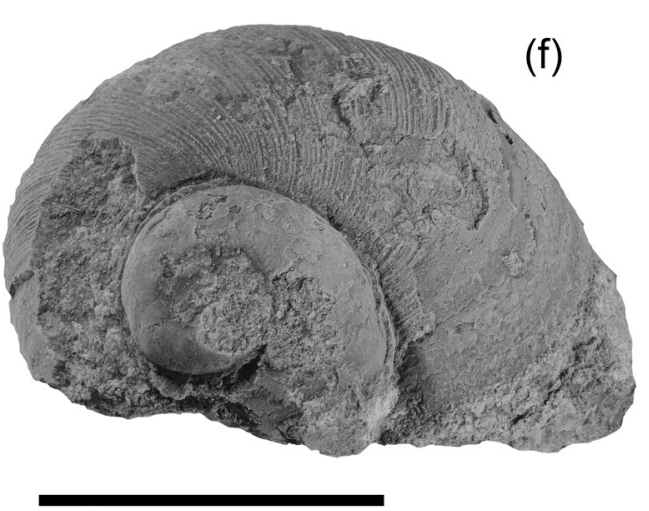

(e)

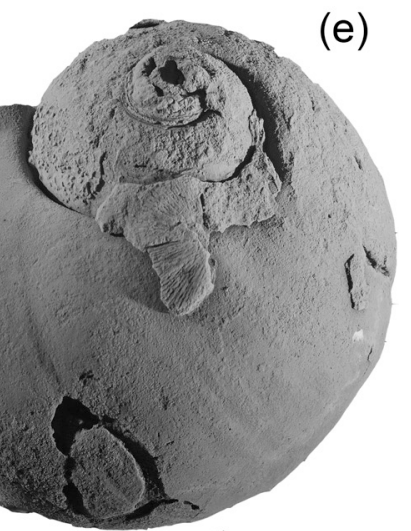

(g)

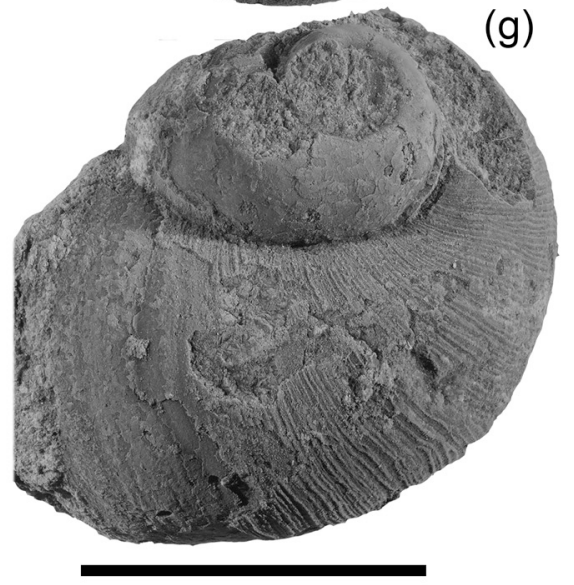


Figure-14.psd @ 33,3\% (Gray/8) *

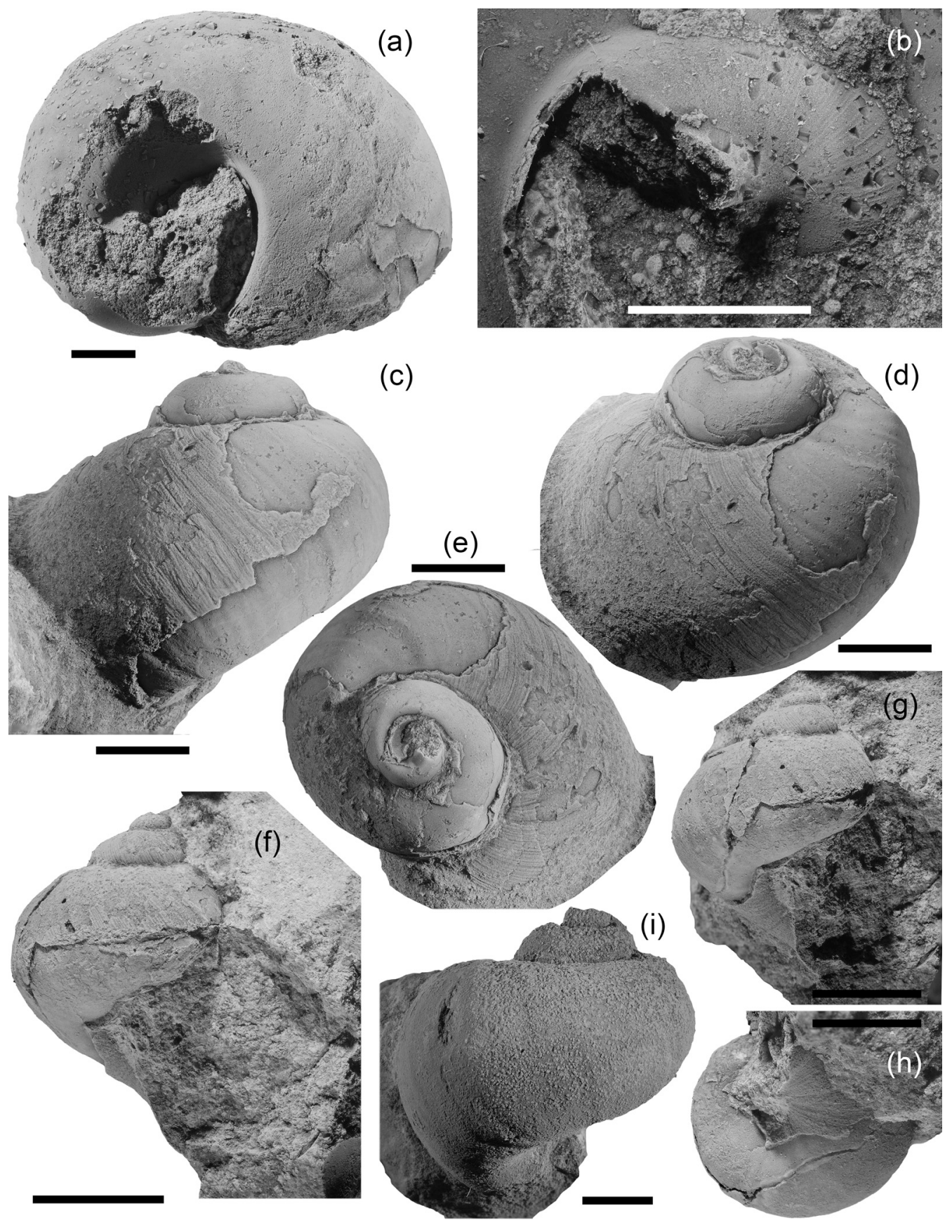


Figure-15.psd @ 33,3\% (Gray/8) *

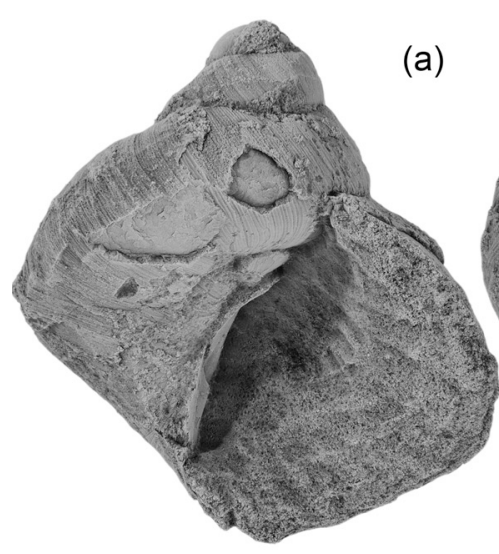

(a)

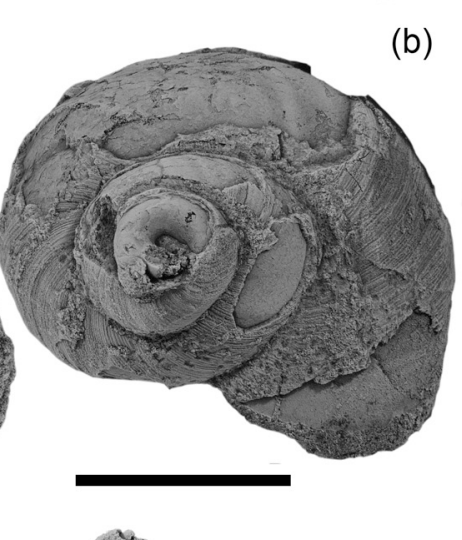

(b)
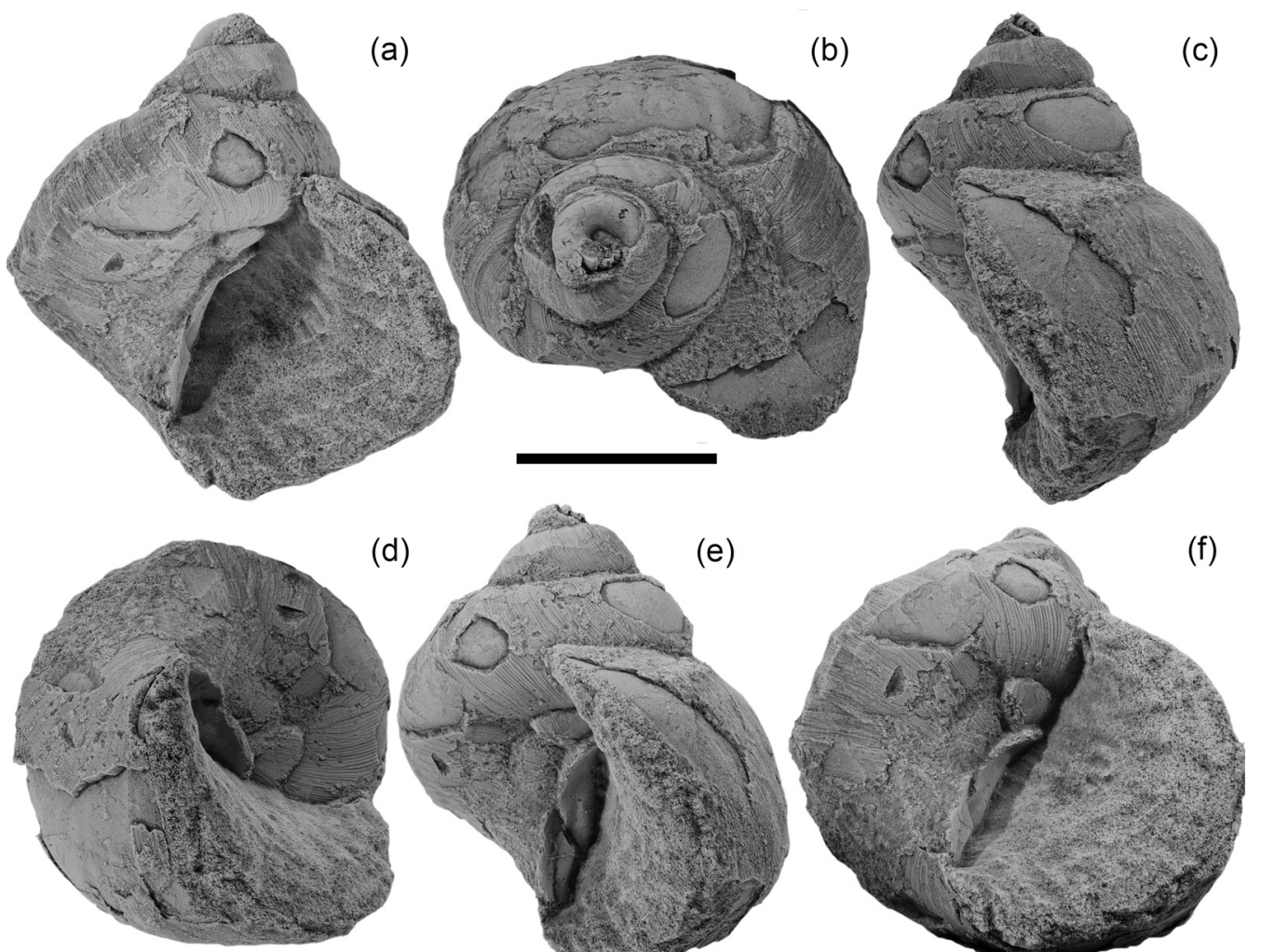

(d)
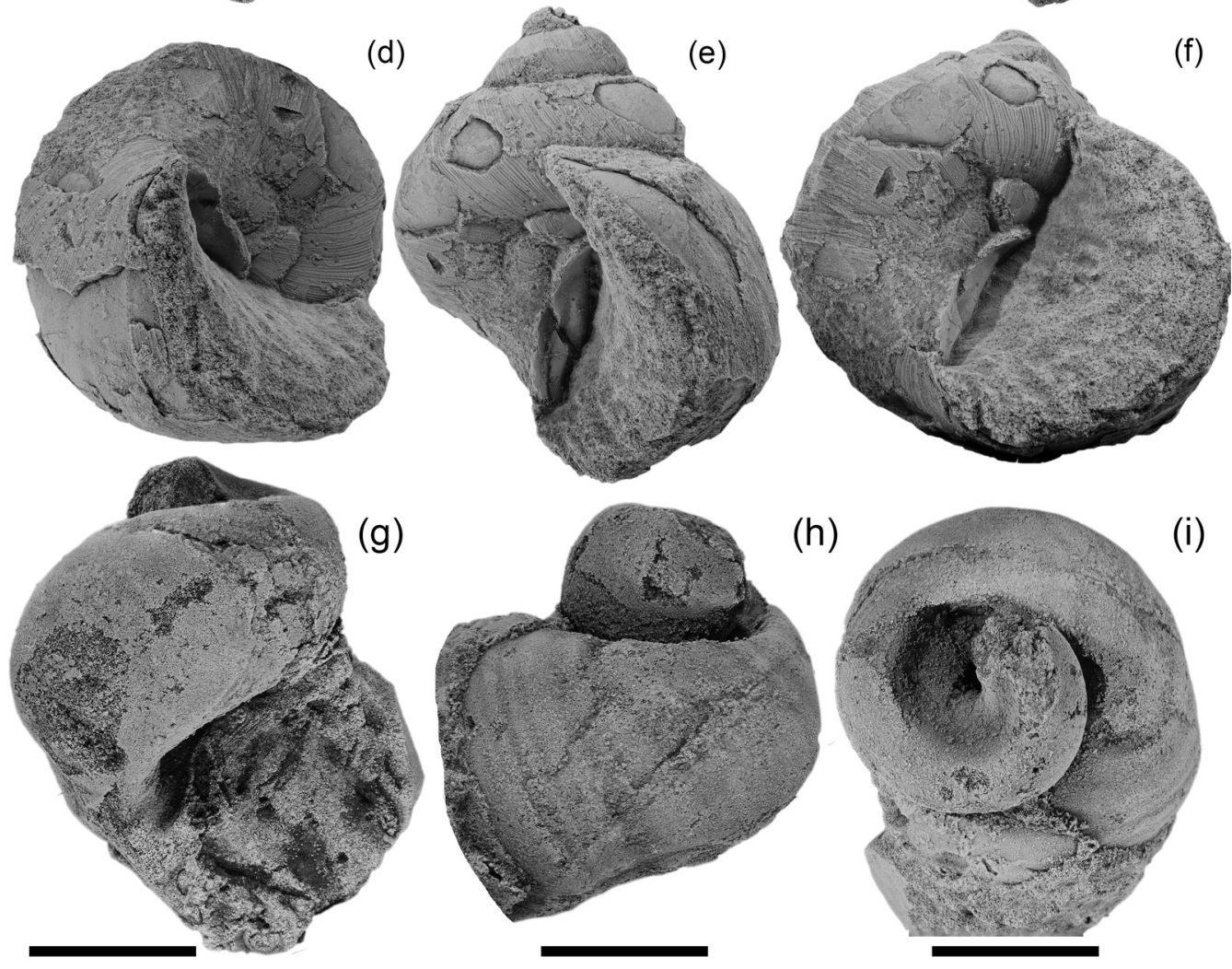

(h) (i)

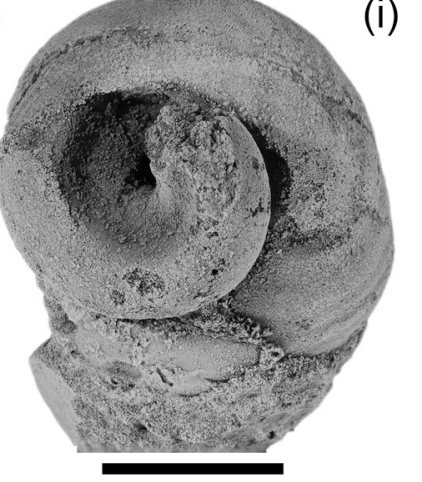




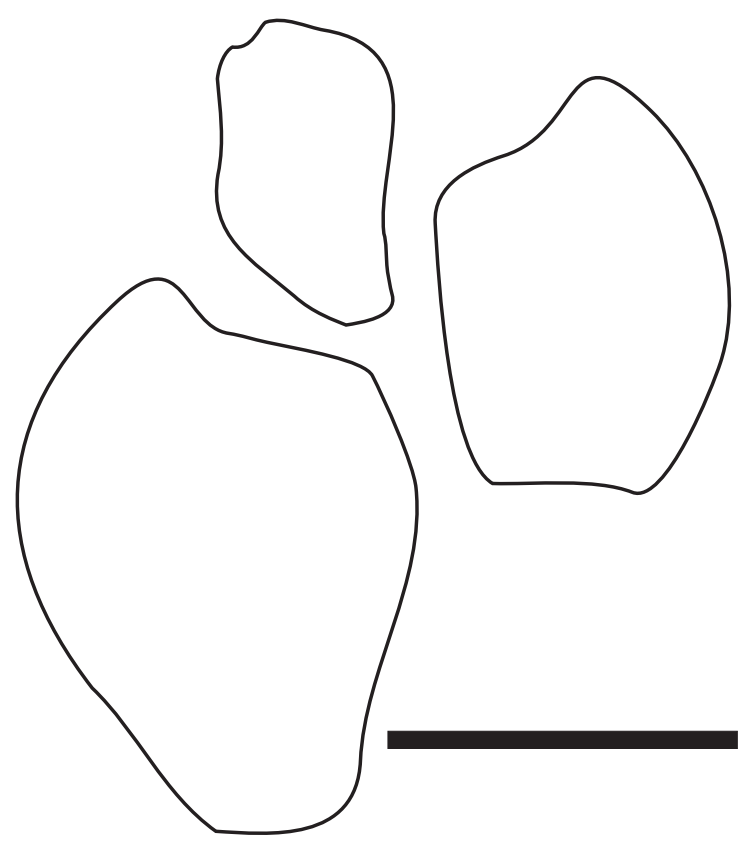


Figure-17.psd @ 2050\% (Layer 0, Gray/8) *

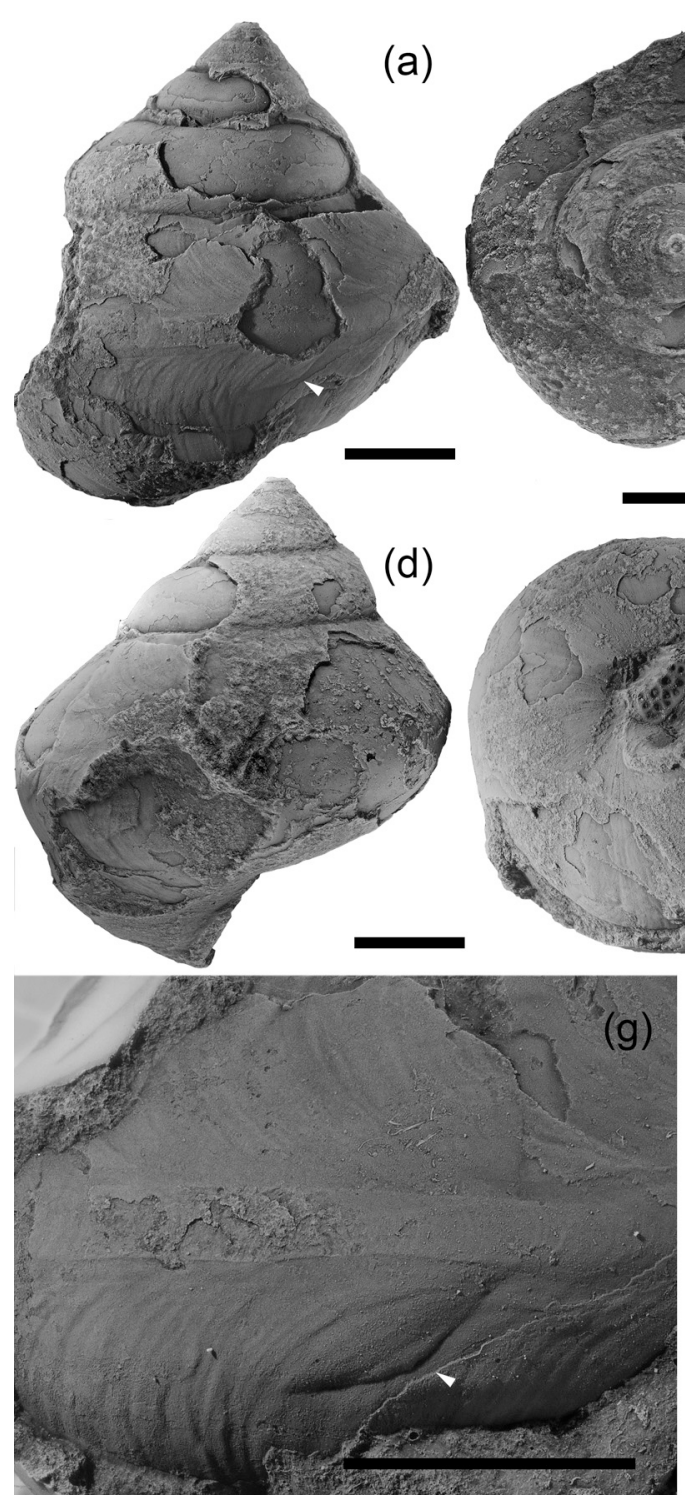

(b)

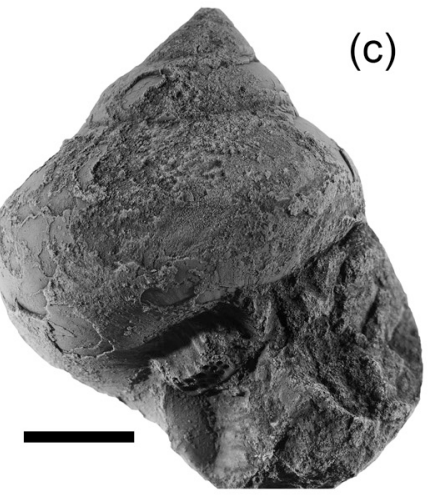

(c)
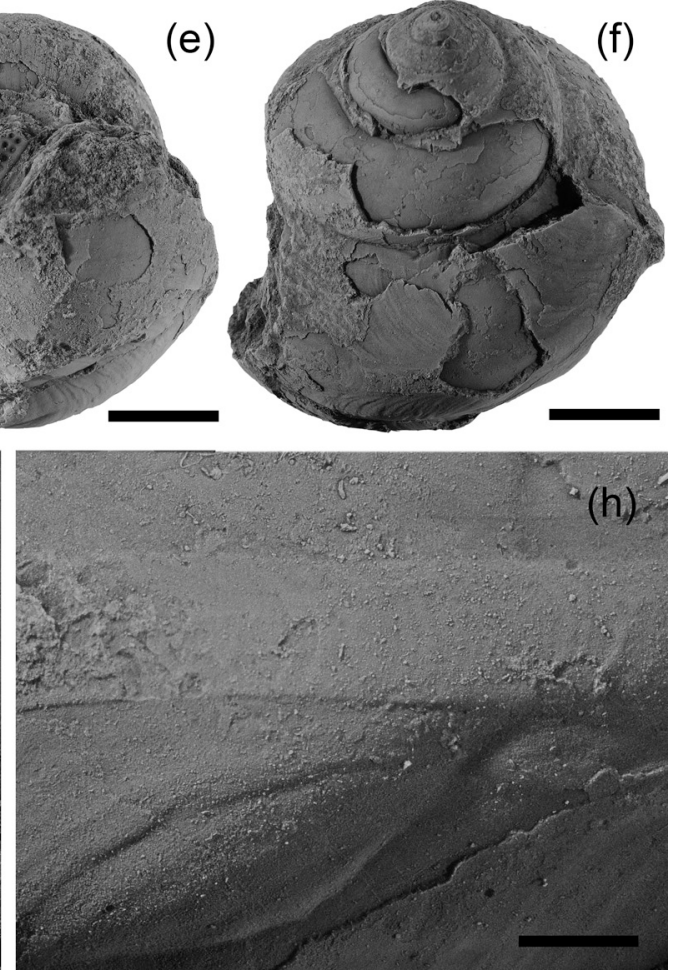
Figure-18.psd @ 33,3\% (Gray/8) *

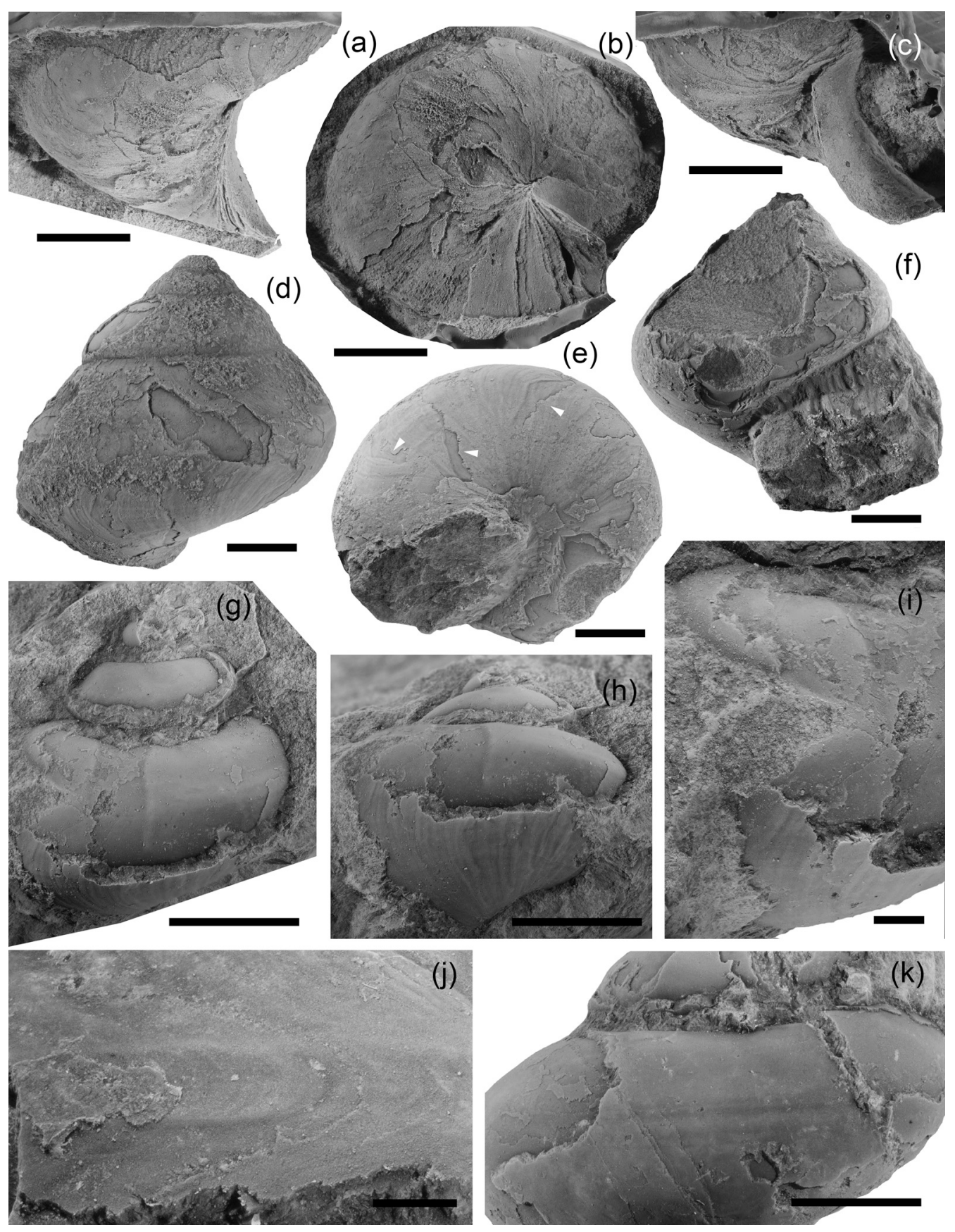


Figure-19.psd @ 66,7\% (Gray/8) *

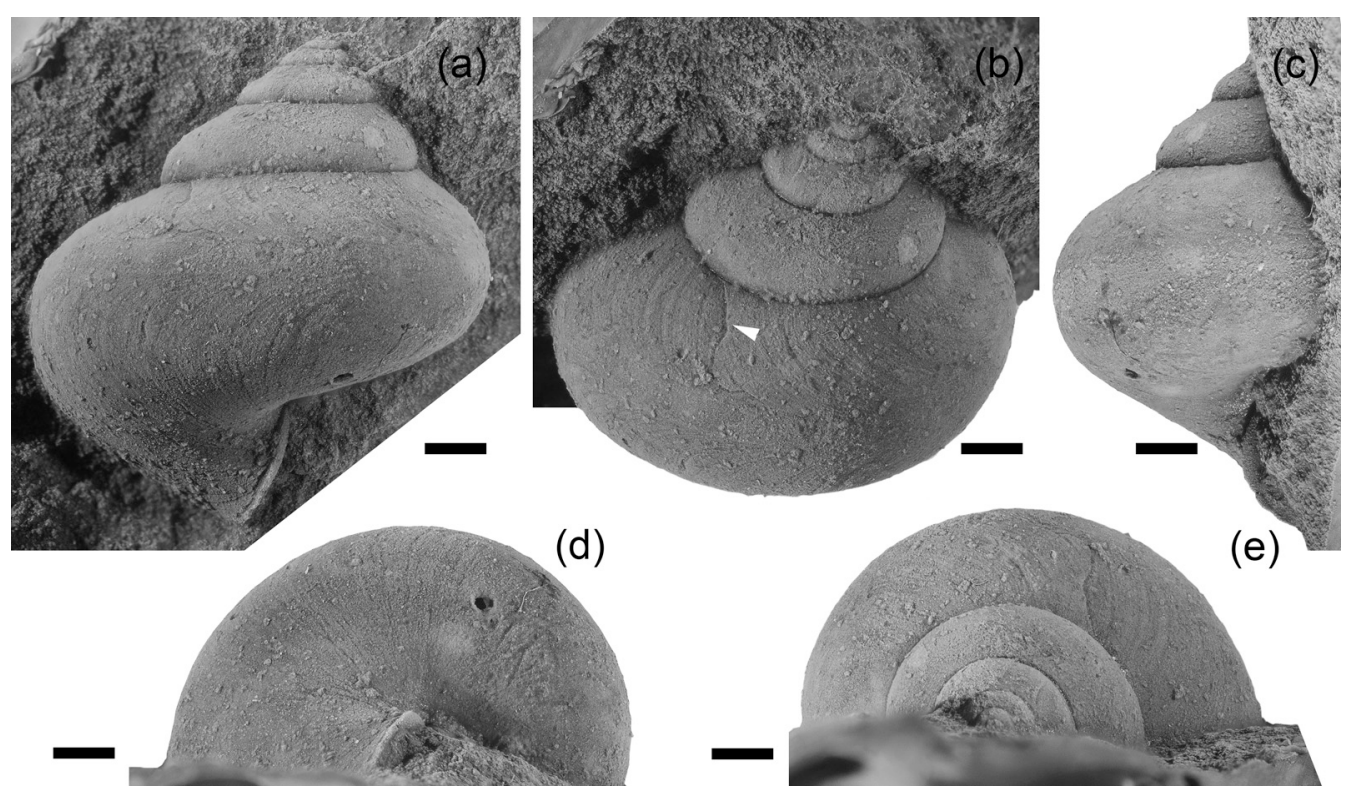


Figure-20.psd @ 33,3\% (Gray/8) *
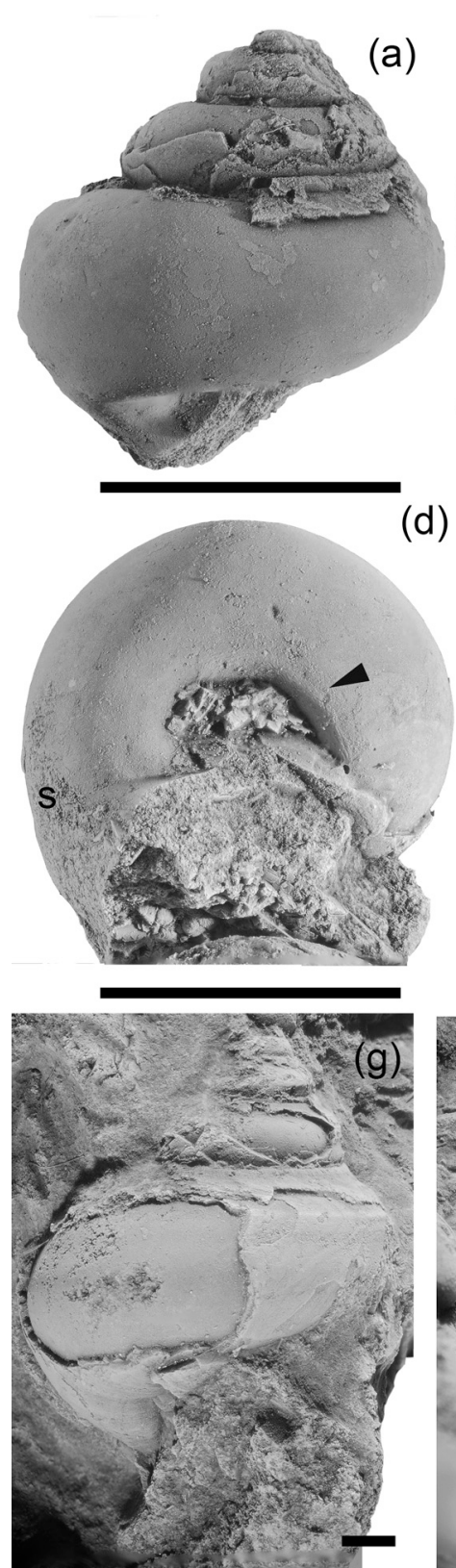

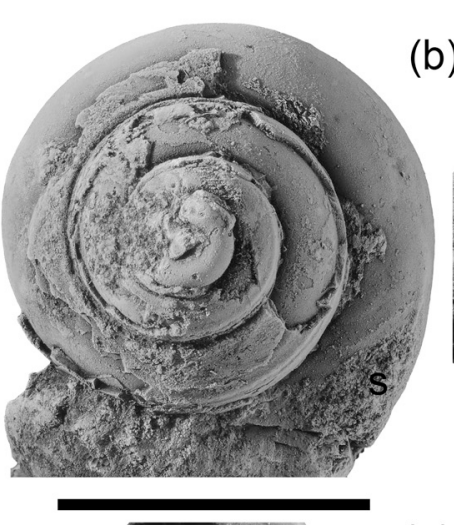

(b)

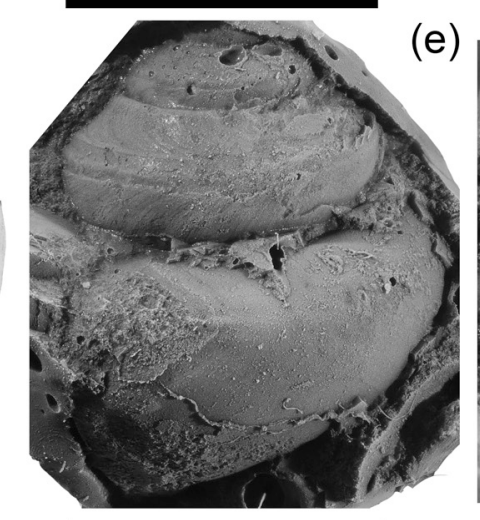

(e)

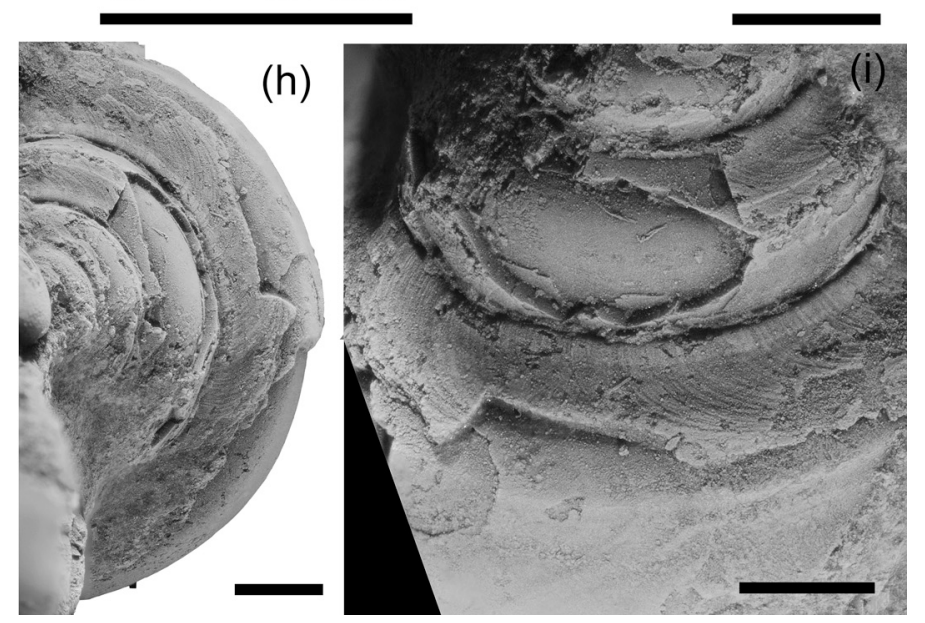

(c)

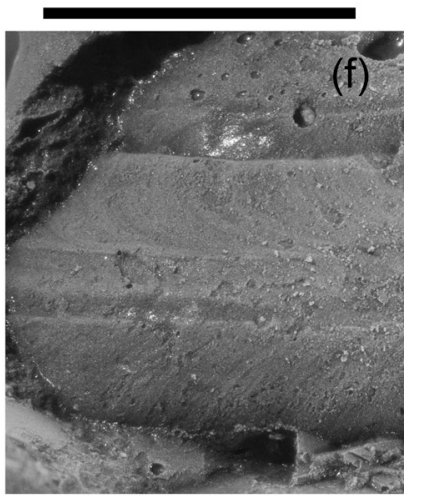

(f) 
Figure-21.psd @ 33,3\% (Gray/8) *

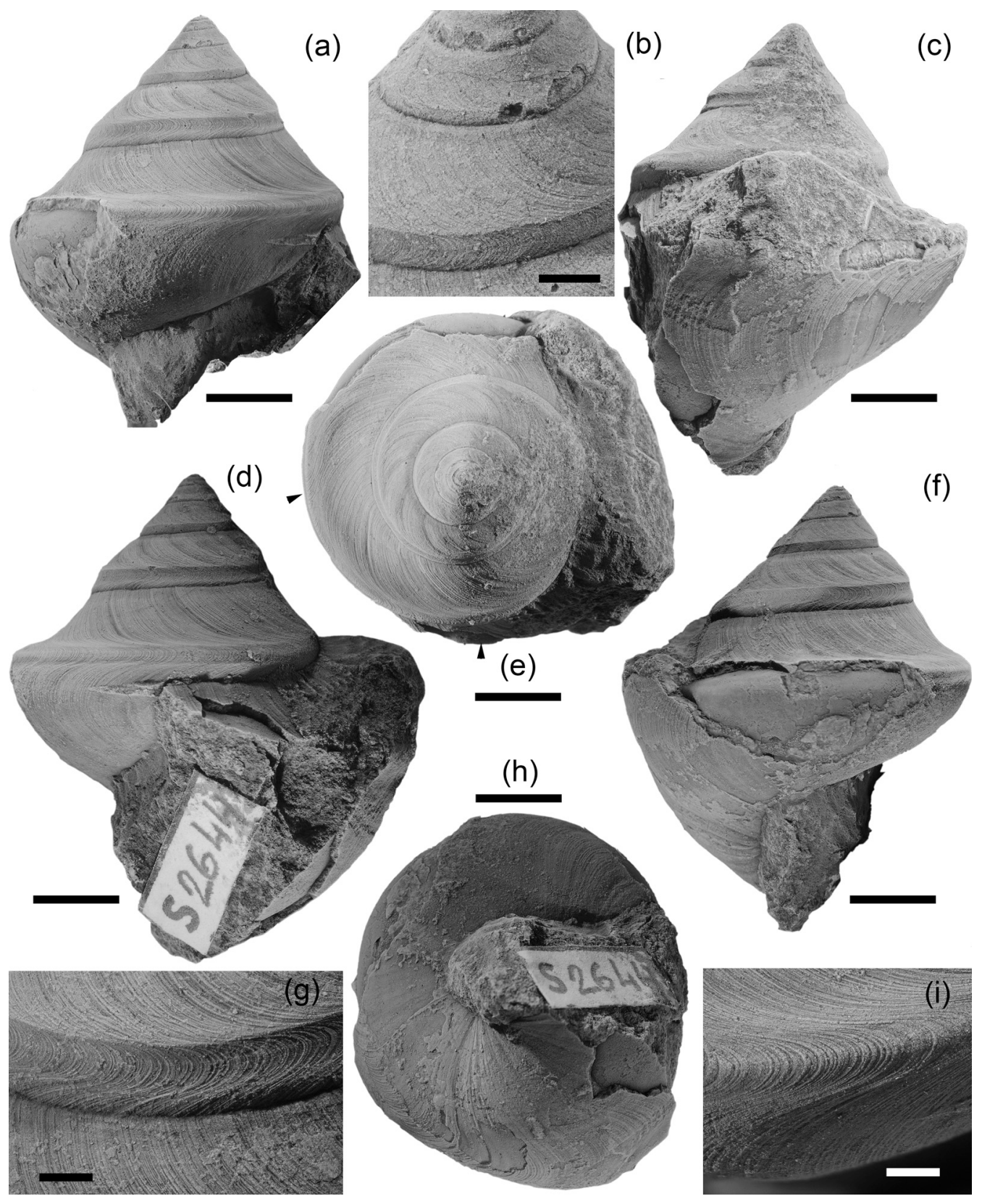


Figure-22.psd @ 33,3\% (Gray/8) *

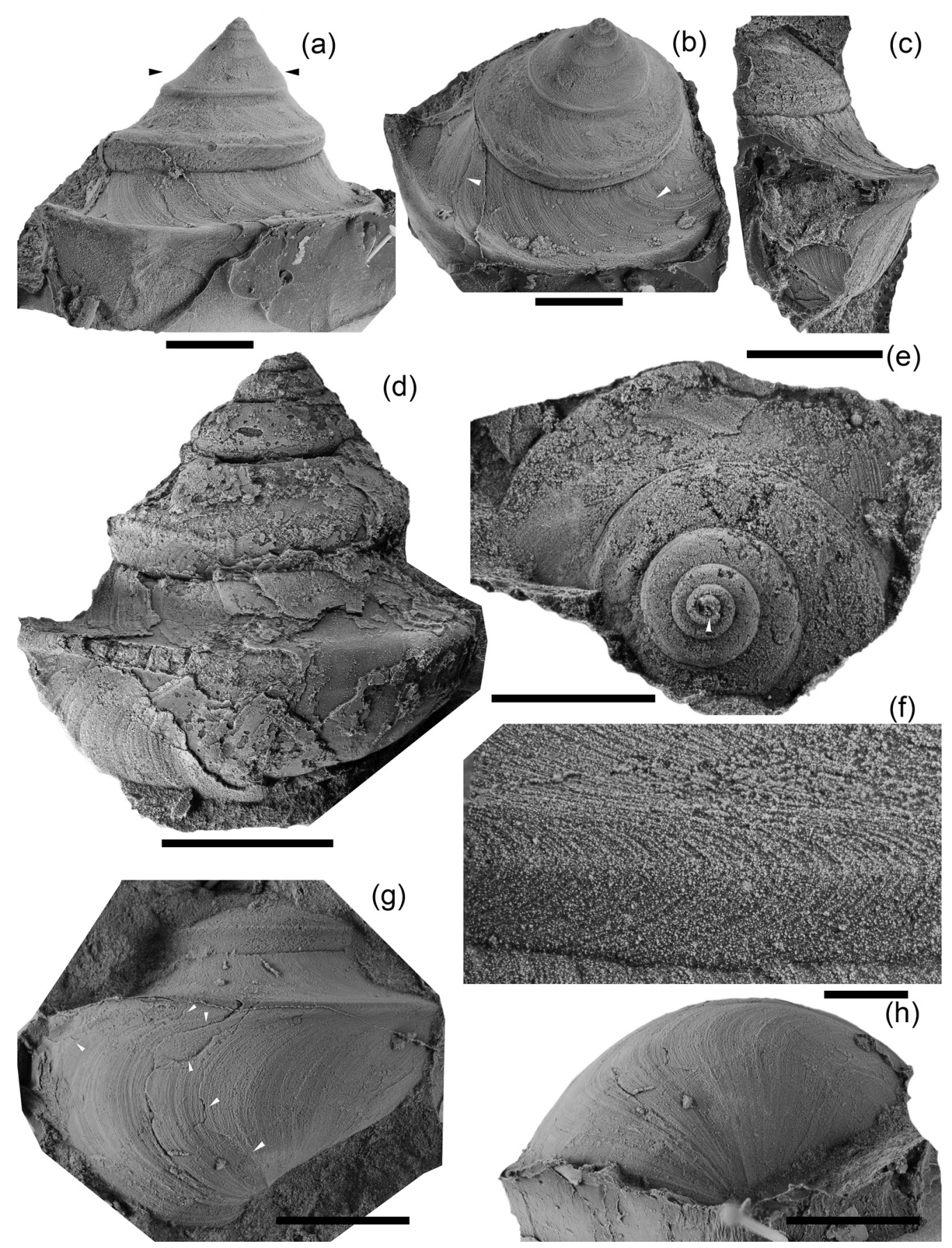


Figure-23.psd @ 66,7\% (Gray/8) *
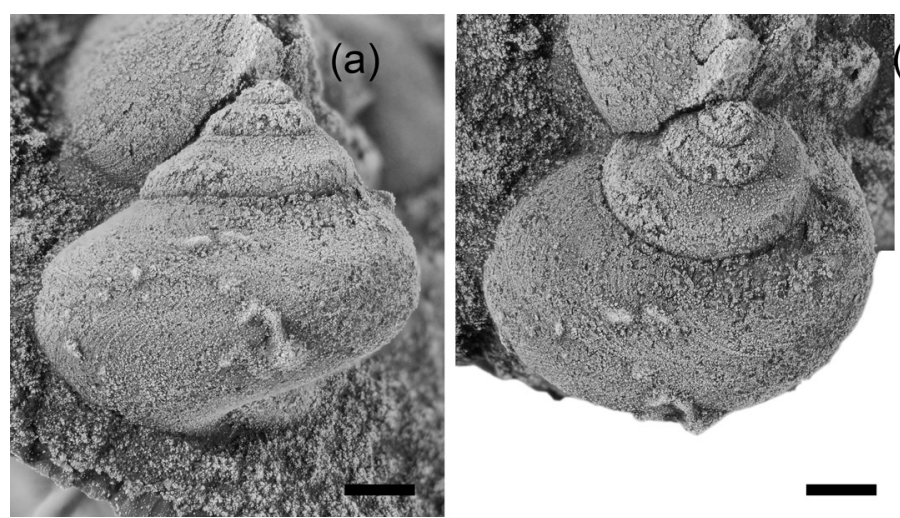

(b)

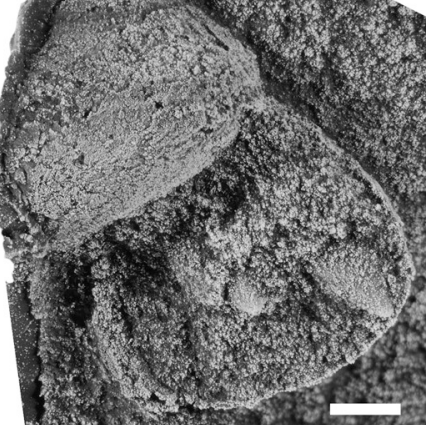


Figure-24.psd @ 100\% (Gray/8) *

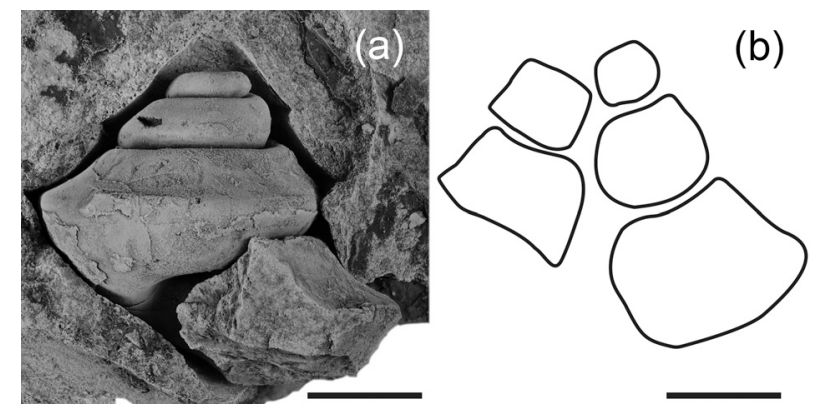


Figure-25.psd @ 33,3\% (Gray/8) *
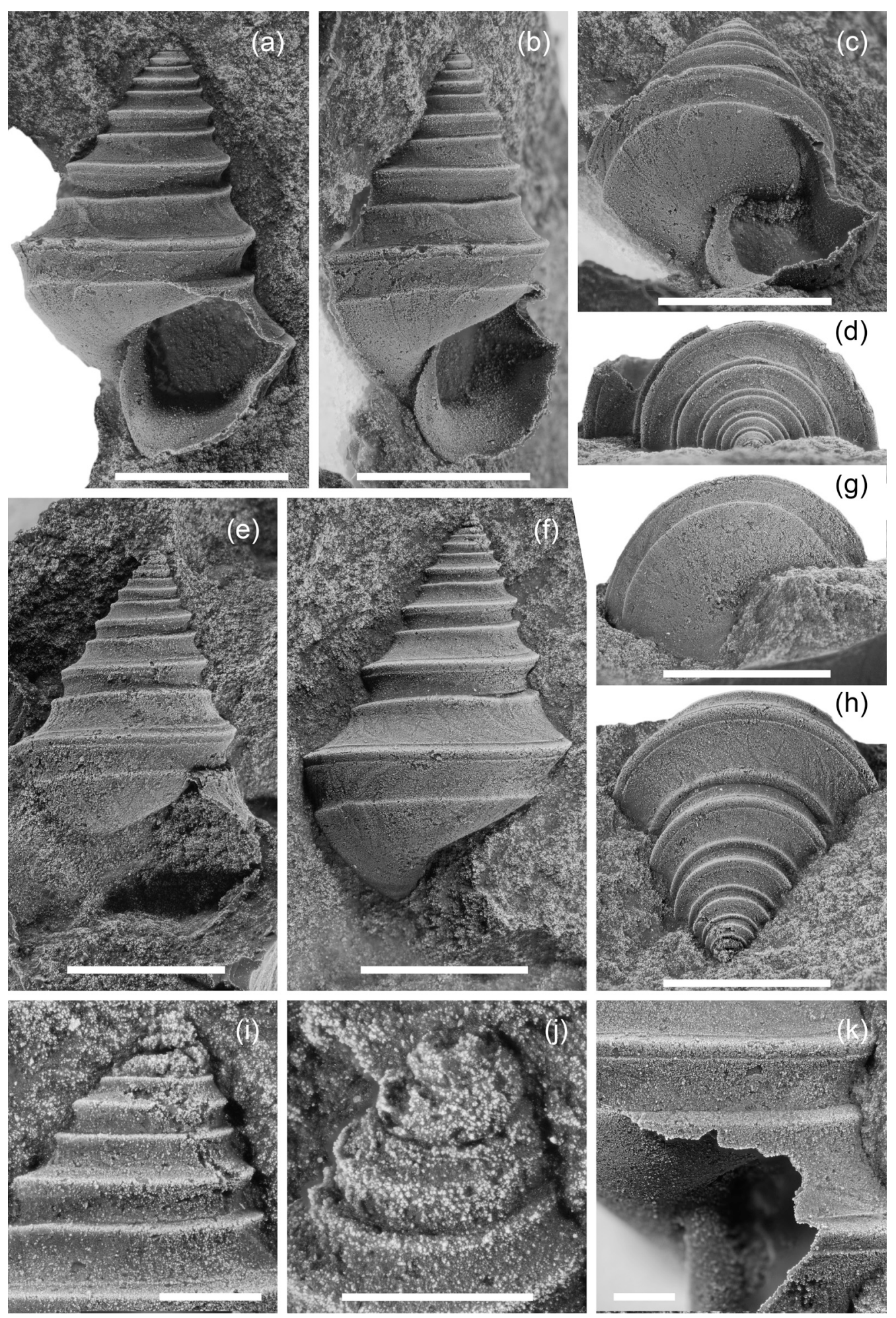
Figure-26.TIF @ 33,3\% (Layer 0, RGB/8\#) *
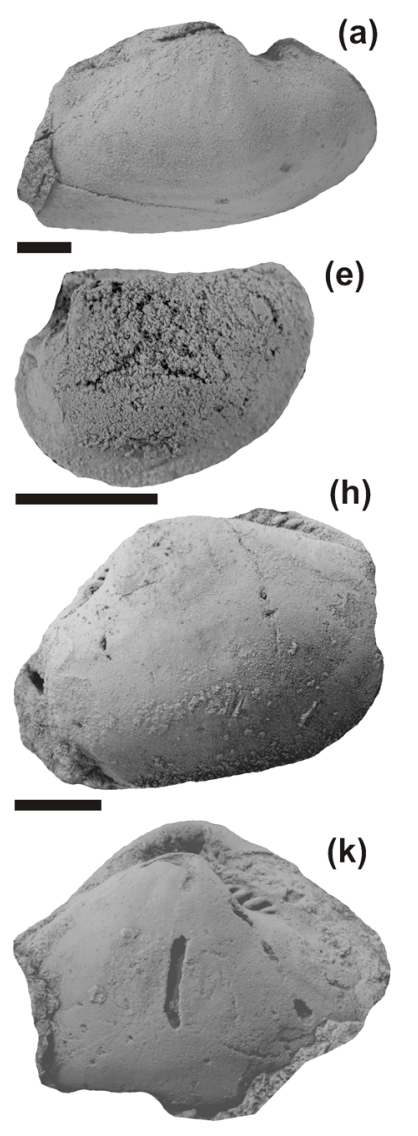

(k)

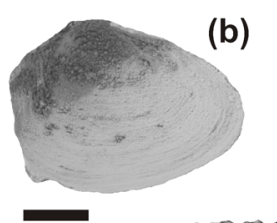

(b)
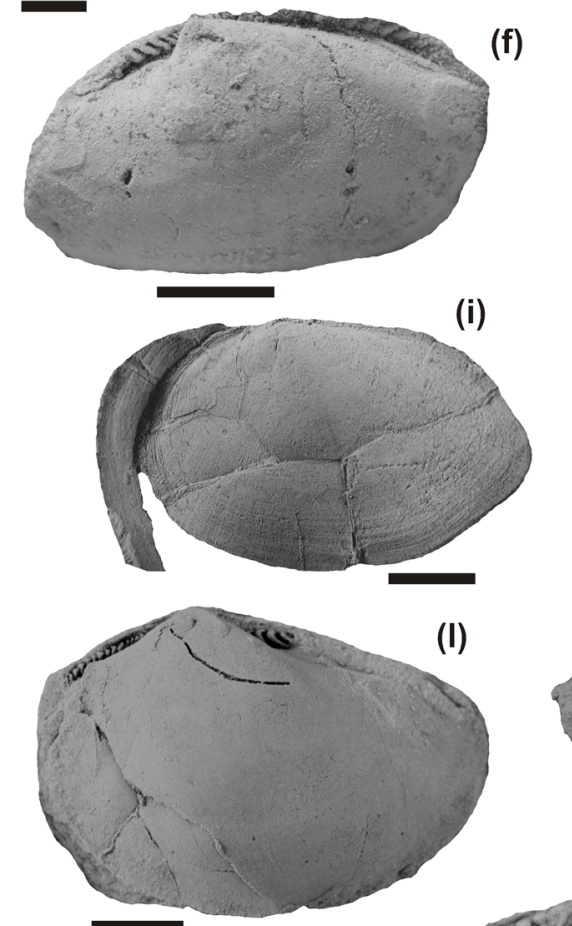

(I) (c)

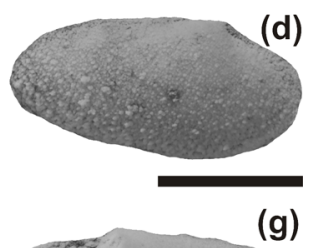

(g)
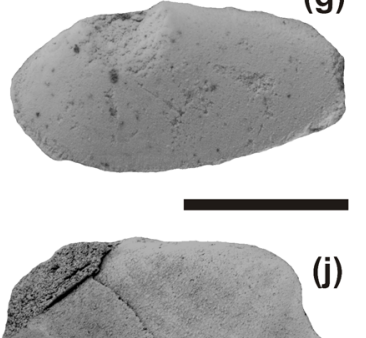

(j)

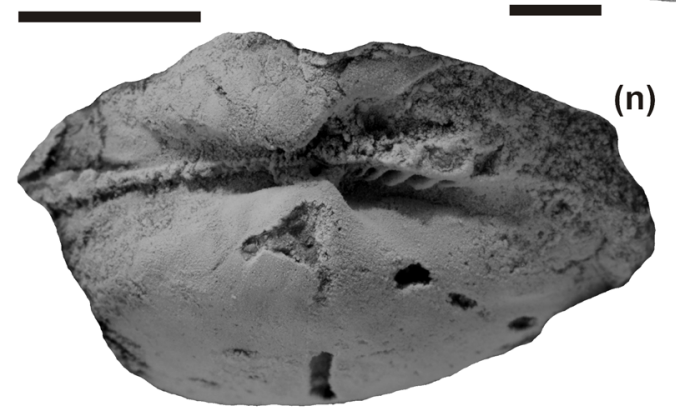

(p)

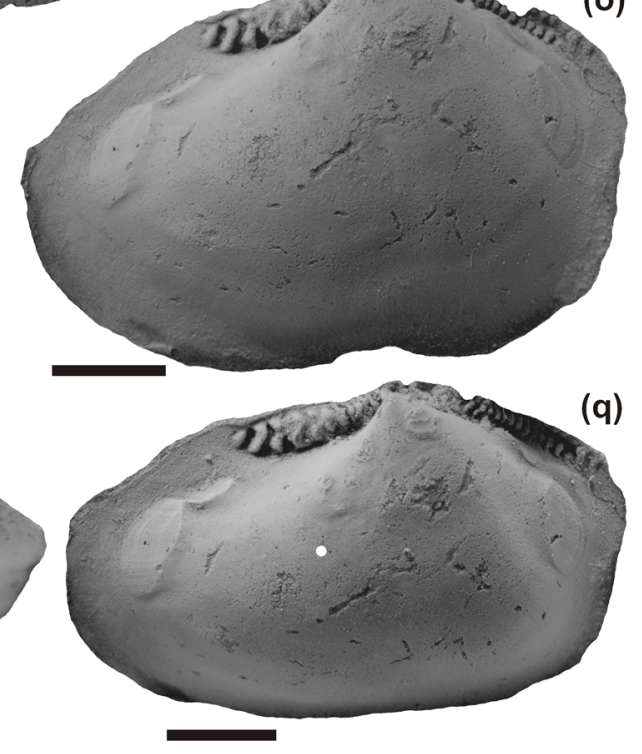


Figure-27.TIF @ 33,3\% (Layer 0, RGB/8\#) *

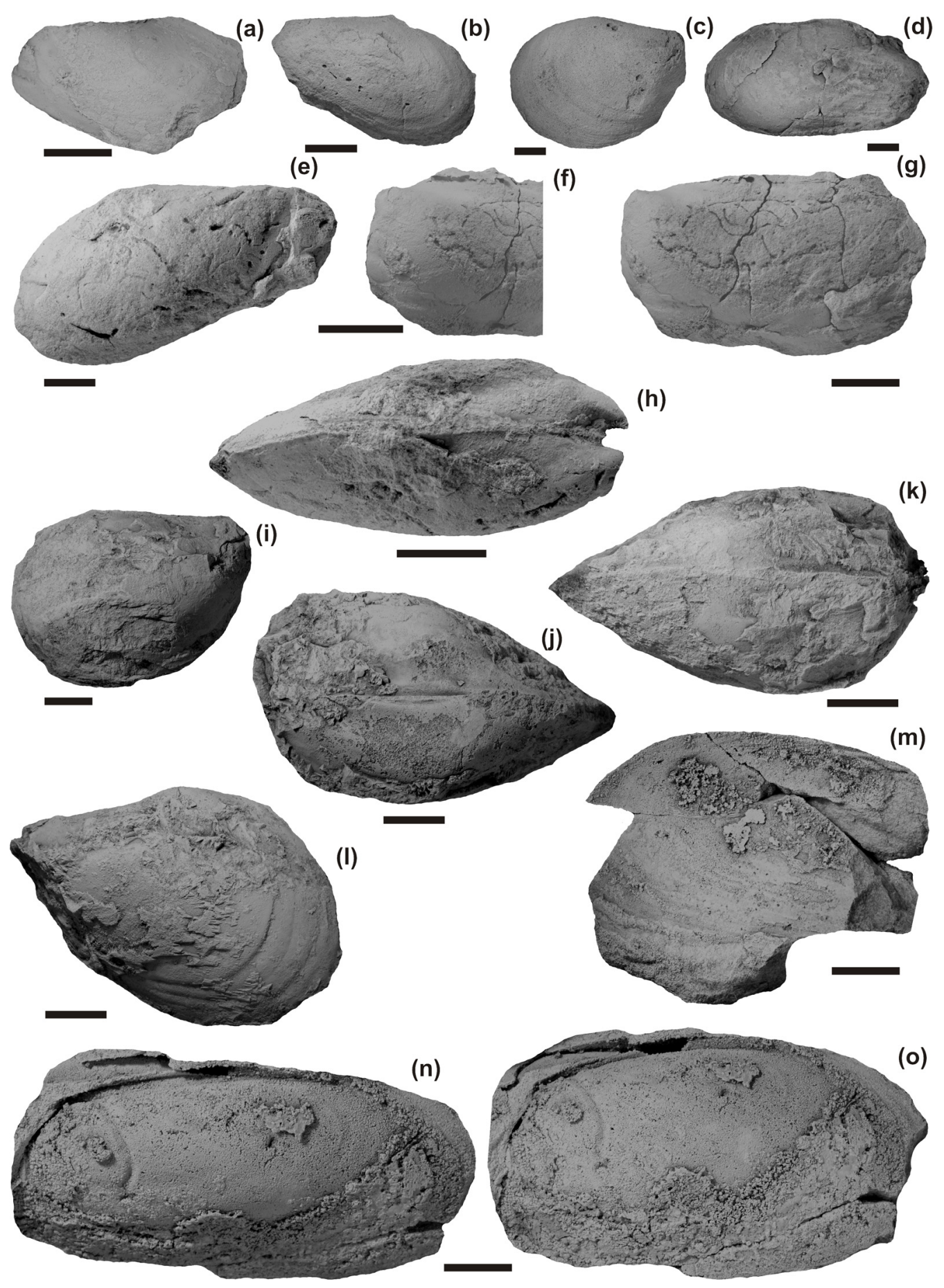



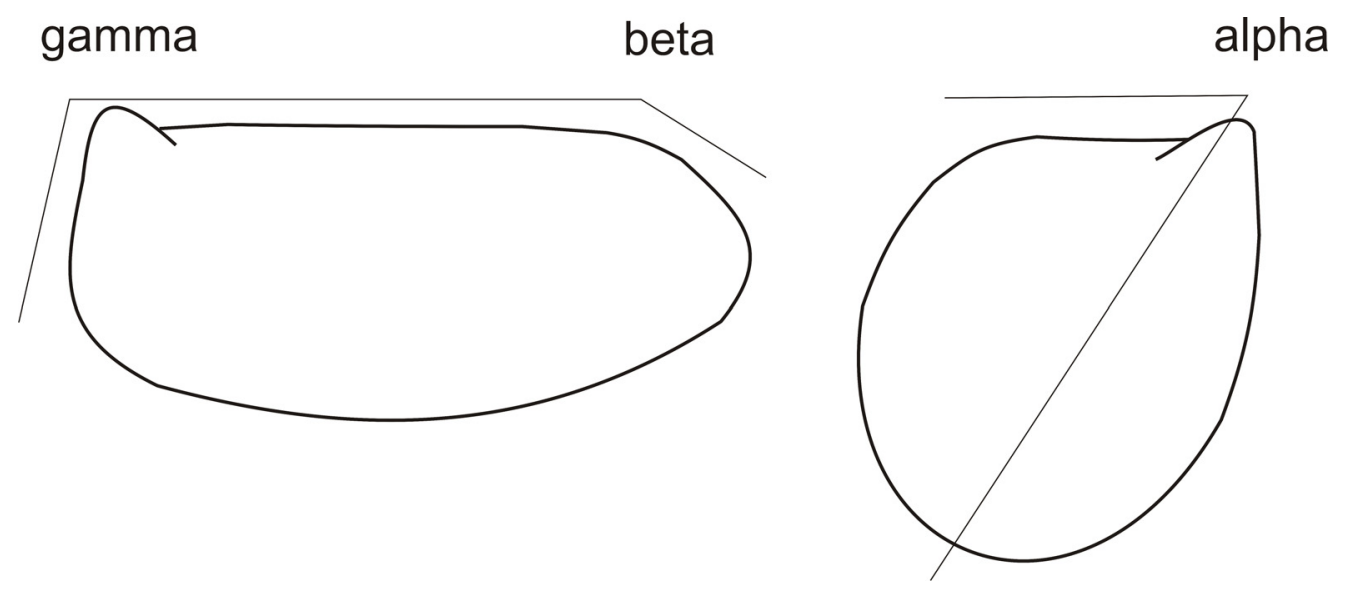
Figure-29.TF @ 33,3\% (RGB/8\#) *

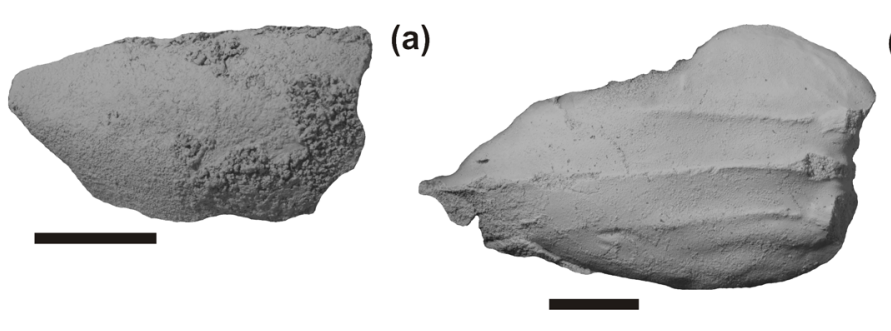

(b)
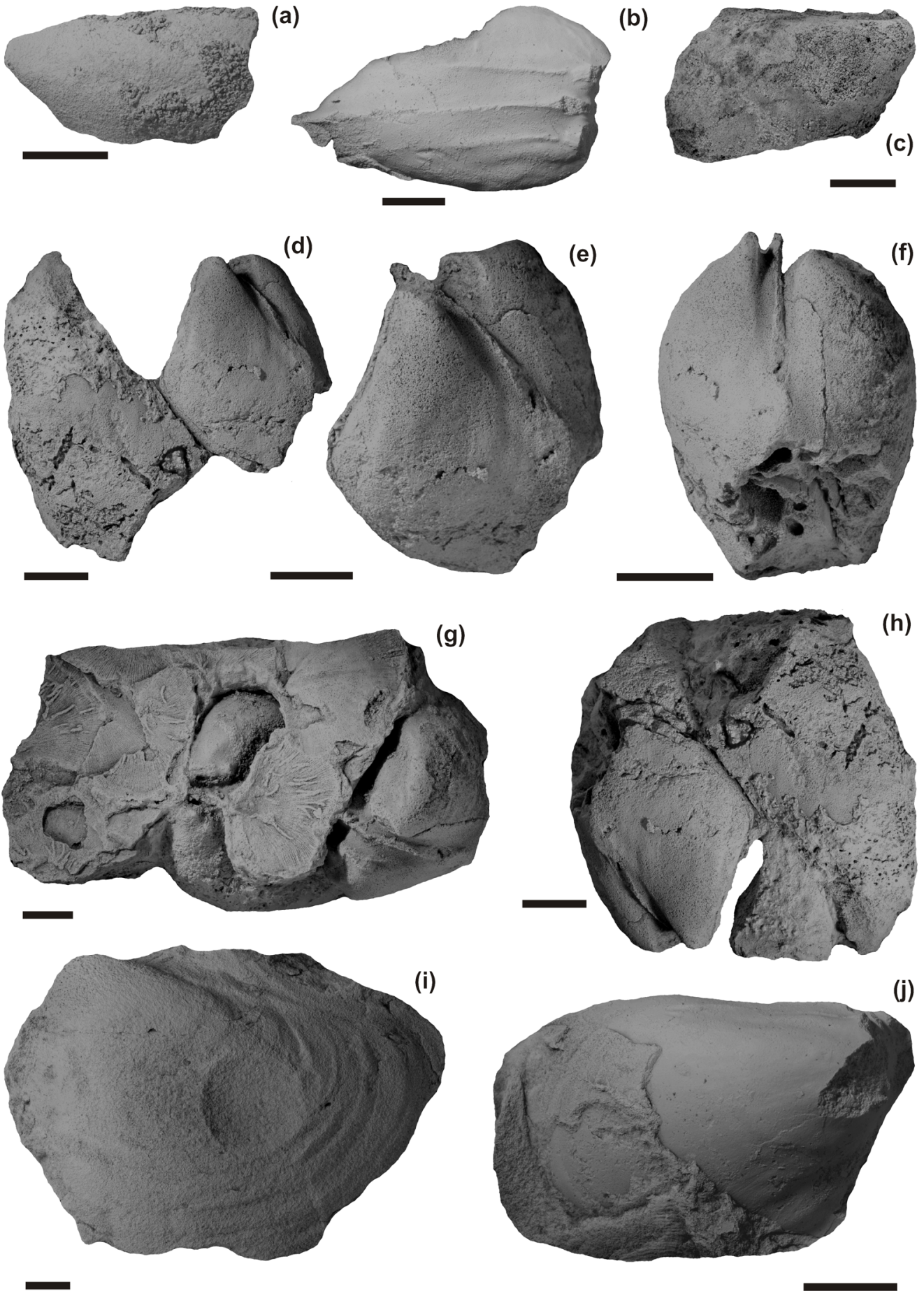
Figure-30.TF @ 33,3\% (RGB/8\#) *

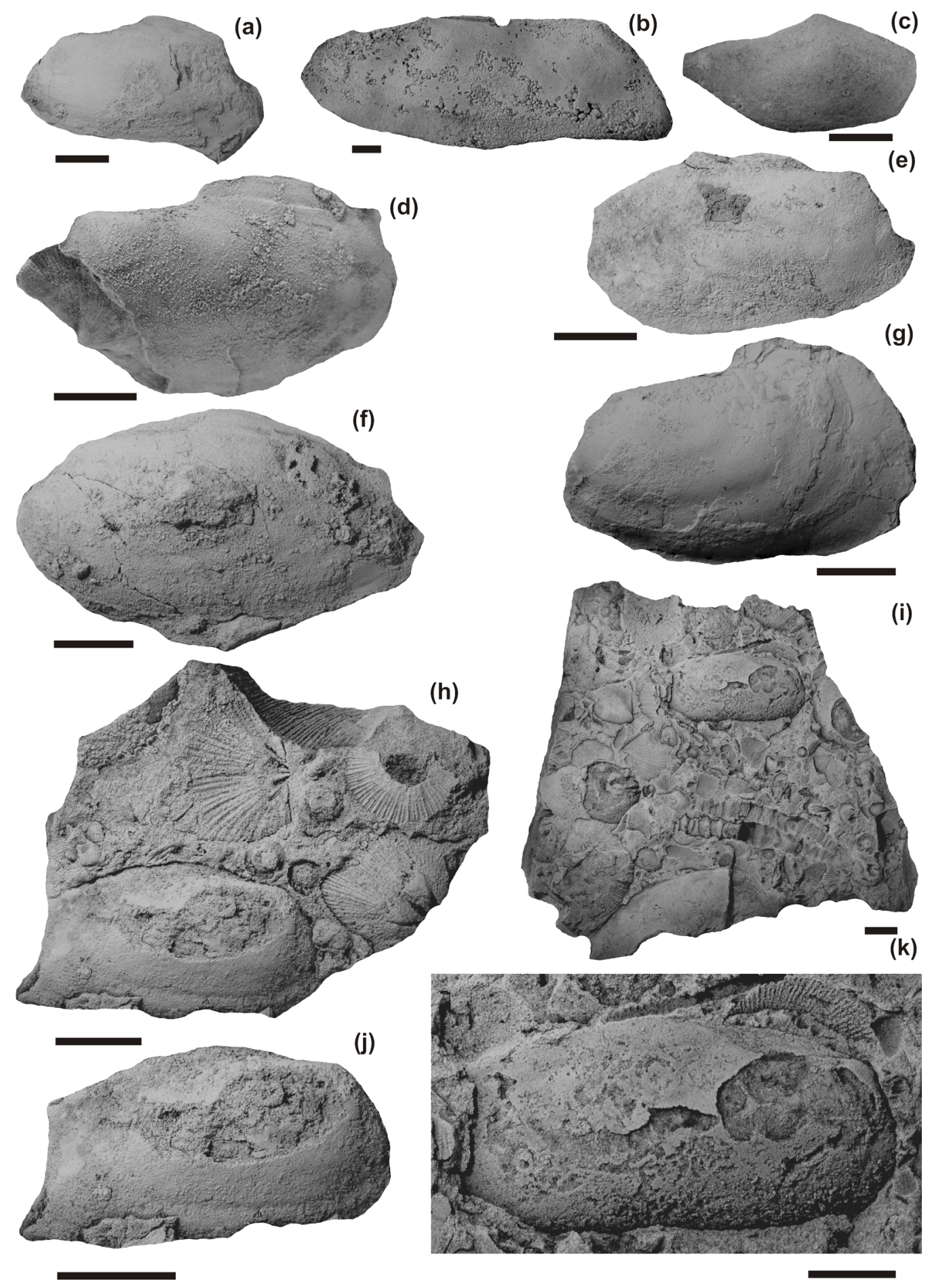




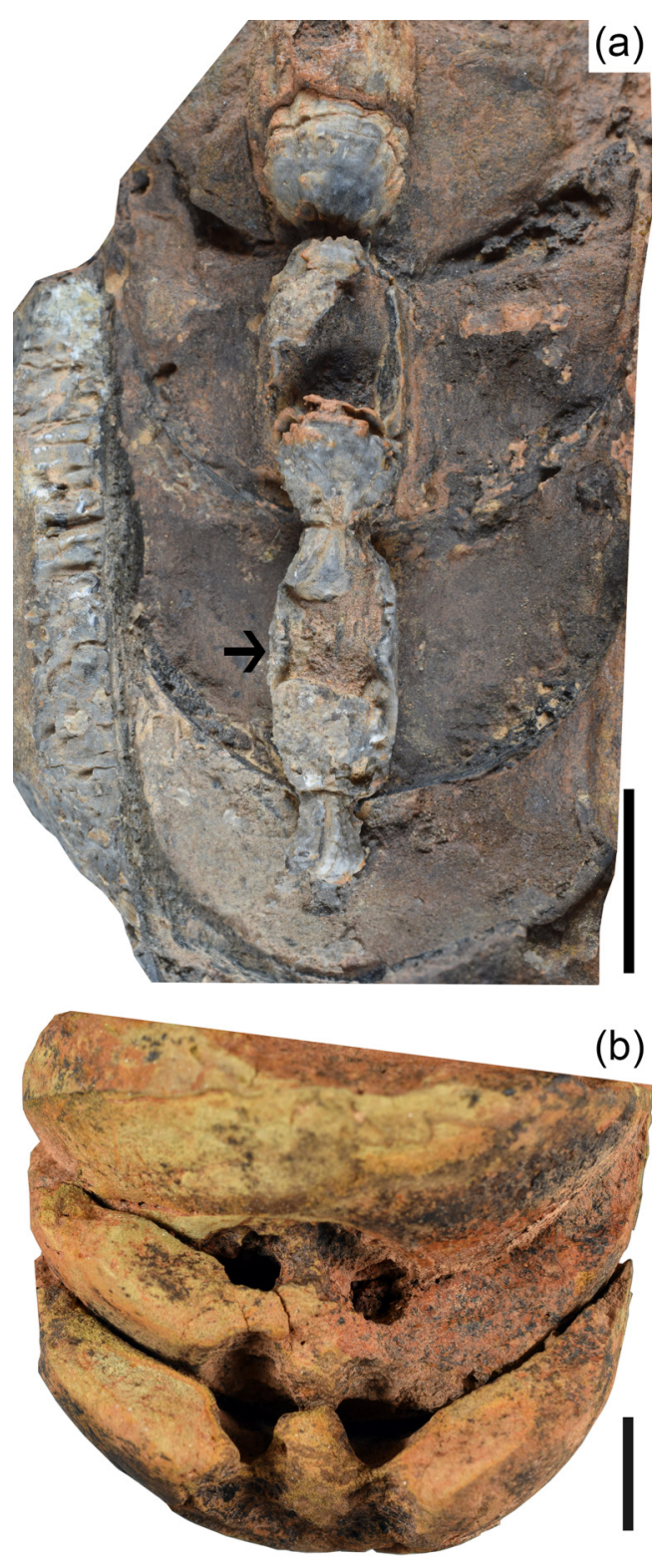




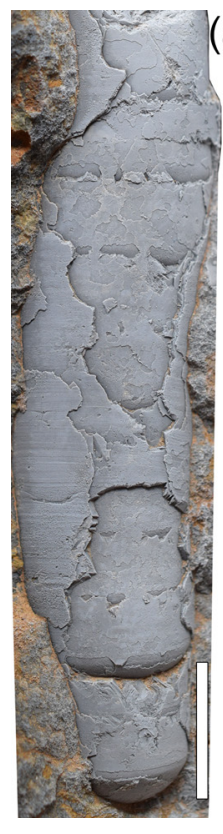

(a) (b)

(b) $\quad$ i

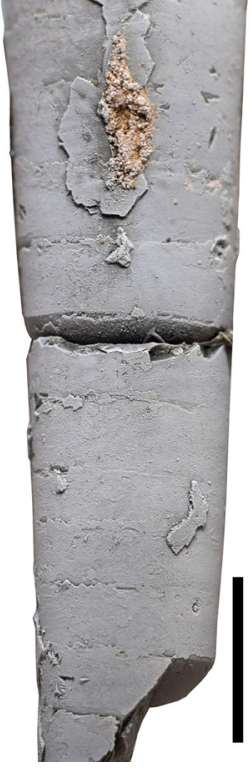

(d)

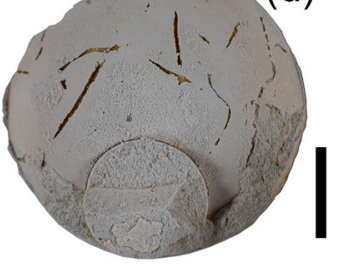

(e)
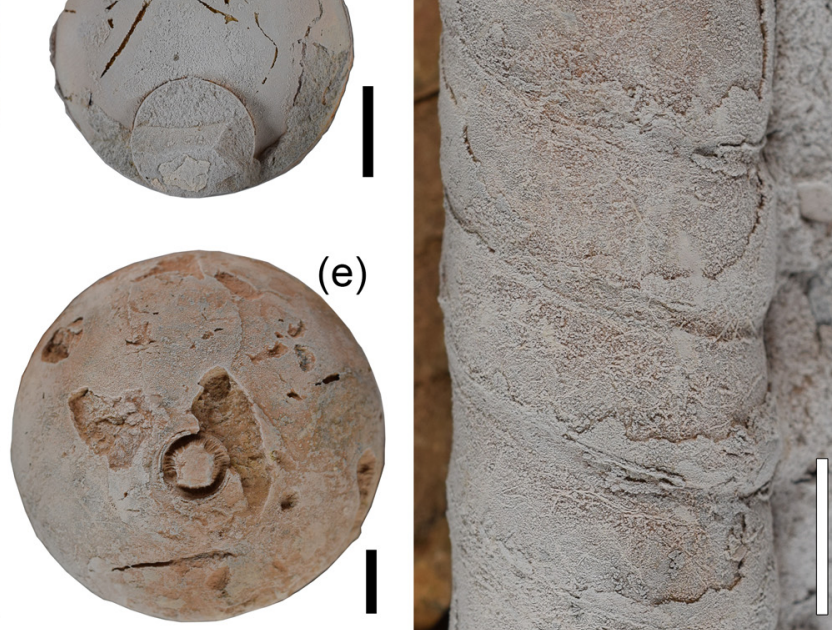

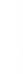


(a)

(b)
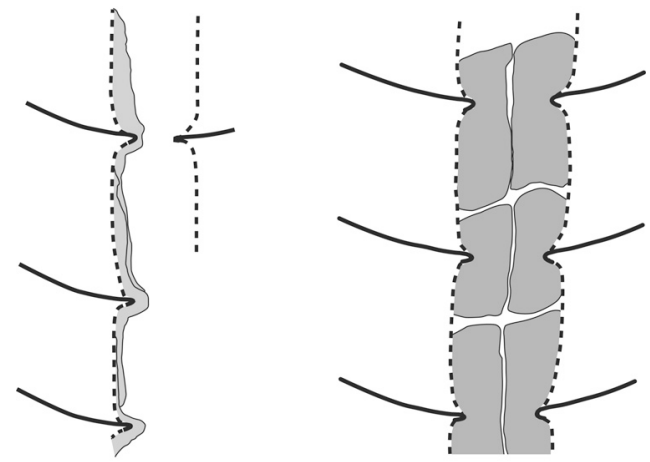

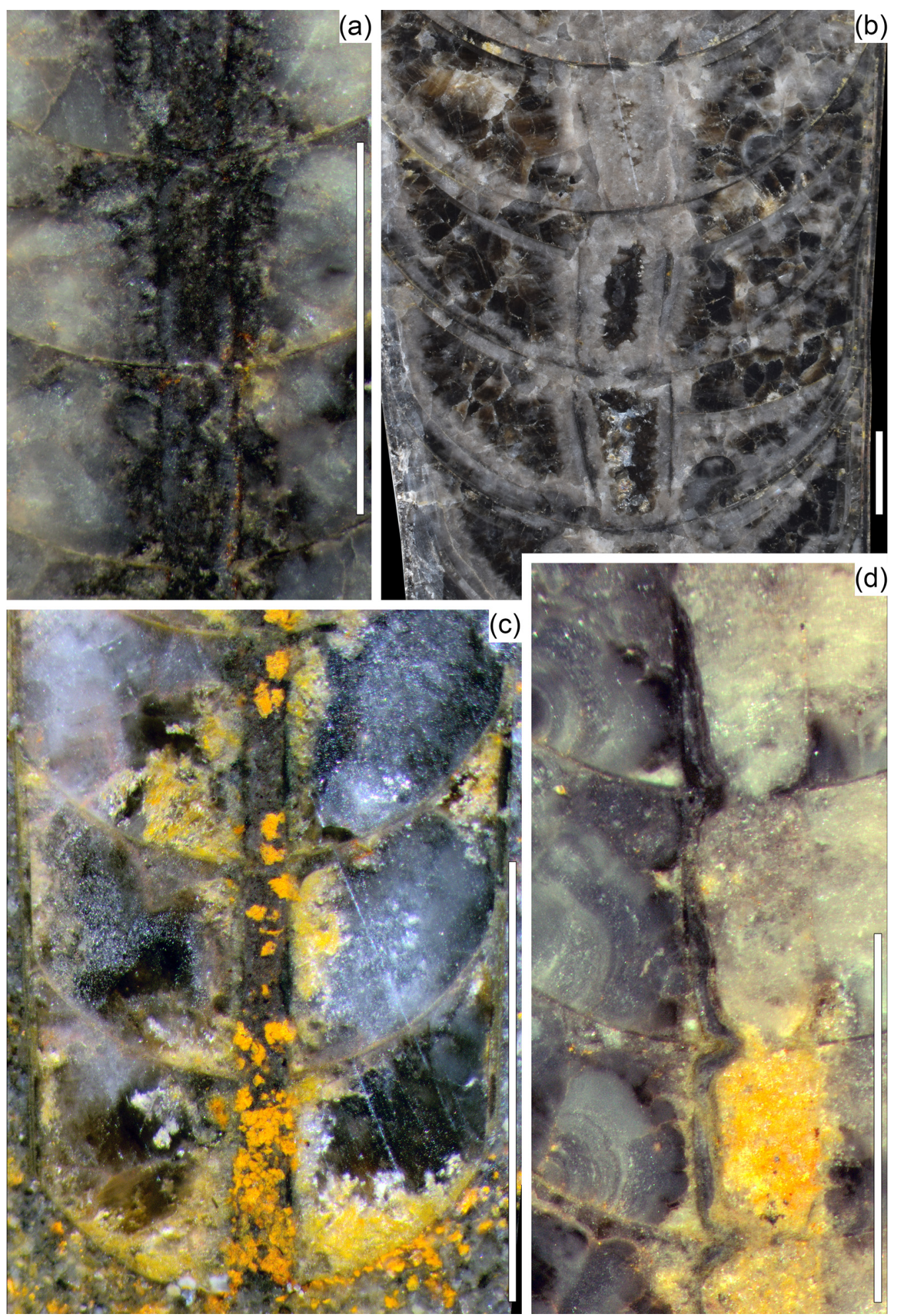
Table 1. Numerical and ranked abundance of bivalves, based on the collections of bivalves from Morocco (Early and Late Ordovician). RV and LV - right and left valves (disarticulated specimens); A - shells with conjoined valves (articulated specimens); RA - percentage relative abundance; AA - percentage relative abundance of shells with conjoined valves; $\mathrm{R}$ - ranked abundance.

Morocco - Early Ordovician

\begin{tabular}{llcccccc}
\hline Species & Life habits & RV & LV & A & RA & AA & R \\
\hline Redonia michelae & infaunal & 42 & 46 & 5 & 66.2 & 6.76 & 1 \\
Babinka prima & infaunal & 7 & 10 & - & 11.50 & 0.00 & 2 \\
Coxiconchia guiraudi & infaunal & 10 & 3 & - & 8.80 & 0.00 & 3 \\
Ekaterodonta courtessolei & infaunal & 6 & 2 & 1 & 6.8 & 1.35 & 4 \\
Aloconcha? & infaunal & 3 & - & - & 2.03 & 0.00 & 5 \\
Cardiolaria? & infaunal & 2 & 1 & - & 2.03 & 0.00 & 6 \\
Glyptarca sp. & infaunal & - & - & 1 & 1.40 & 1.35 & 7 \\
Cienagomya? & infaunal & - & 1 & - & 0.68 & 0.00 & 8 \\
Praenucula? & infaunal & 1 & - & - & 0.68 & 0.00 & 9 \\
Totals & & 71 & 63 & 7 & $100.12 \%$ & $9,46 \%$ &
\end{tabular}

Morocco - Late Ordovician

\begin{tabular}{|c|c|c|c|c|c|c|c|}
\hline Species & Life habits & $\mathrm{RV}$ & LV & A & RA & $\mathrm{AA}$ & $\mathrm{R}$ \\
\hline Praenucula pojetai & infaunal & 5 & 3 & 1 & 20.0 & 20.0 & 1 \\
\hline Modiolopsis sp. & semi-infaunal & 3 & 7 & - & 20.0 & - & 1 \\
\hline Cyrtodonta sp. & semi-infaunal & 1 & 1 & 2 & 12.0 & 66.7 & 2 \\
\hline Cleionychia prisca & epifaunal & 1 & 2 & 1 & 10.0 & 40.0 & 3 \\
\hline Myoplusia sp. & infaunal & 2 & 3 & - & 10.0 & - & 3 \\
\hline Dceruska sp. & semi-infaunal & - & 1 & 1 & 6.0 & 66.7 & 4 \\
\hline Nuculites sp. & infaunal & - & 1 & 1 & 6.0 & 66.7 & 4 \\
\hline Sluha kosoviensis & infaunal & - & 2 & - & 4.0 & - & 4 \\
\hline Ambonychia sp. & epifaunal & - & - & 1 & 4.0 & 100.0 & 4 \\
\hline Phestia? sp. & infaunal & 1 & - & - & 2.0 & - & 5 \\
\hline Pseudarca? sp. & infaunal & 1 & - & - & 2.0 & - & 5 \\
\hline Cleionychia transversa & epifaunal & - & 1 & - & 2.0 & - & 5 \\
\hline Ambonychia aff. magna & epifaunal & - & 1 & - & 2.0 & - & 5 \\
\hline Totals & & 14 & 22 & 7 & $100.0 \%$ & $28.0 \%$ & \\
\hline
\end{tabular}


Table 2. Dimensions and type of the valve in Praenucula pojetai sp. nov.

Abreviations: $\mathrm{V}=$ valve $(\mathrm{R}=$ right valve, $\mathrm{L}=$ left valve, $\mathrm{A}=$ articulated specimen $), \mathrm{L}=$ length of the valve, $\mathrm{H}=$ height of the valve, $\mathrm{W}=$ width of the valve.

\begin{tabular}{lllll}
\hline Dimensions. & $\mathrm{V}$ & $\mathrm{L}$ & $\mathrm{H}$ & $\mathrm{W} / 2$ \\
\hline FSL 550118 & $\mathrm{R}$ & 22.5 & 14.2 & 2.0 \\
MGM-6845X & $\mathrm{L}$ & 22.2 & 15.0 & 2.1 \\
MGM-6844X & $\mathrm{R}$ & 20.1 & 14.8 & 2.5 \\
FSL 550113 & $\mathrm{R}$ & 15.5 & 11.1 & 1.5 \\
FSL 550161 & $\mathrm{R}$ & 12.5 & 7.7 & 1.0 \\
MGM-6849X & $\mathrm{R}$ & - & 18.4 & - \\
MGM-6846X & $\mathrm{L}$ & - & 12.1 & 1.9 \\
MGM-6843X & $\mathrm{A}$ & - & - & 4.0 \\
MGM-6848X & $\mathrm{L}$ & - & - & 1.5 \\
\hline
\end{tabular}

Table 3. Dimensions and type of the valve in Nuculites sp.

Abreviations: $\mathrm{V}=$ valve $(\mathrm{R}=$ right valve, $\mathrm{L}=$ left valve, $\mathrm{A}=$ articulated specimen $), \mathrm{L}=$ length of the valve, $\mathrm{H}=$ height of the valve, $\mathrm{W}=$ width of the valve.

\begin{tabular}{lllll}
\hline Dimensions. & V & L & H & W/2 \\
\hline MGM-6860X & A & 96.5 & 48.7 & 16.1 \\
MGM-6862X & L & 59.2 & 32.2 & 7.2 \\
\hline
\end{tabular}

Table 4. Dimensions and type of the valve in Myoplusia sp.

Abreviations: $\mathrm{V}=$ valve $(\mathrm{R}=$ right valve, $\mathrm{L}=$ left valve, $\mathrm{A}=$ articulated specimen $), \mathrm{L}=$ length of the valve, $\mathrm{H}=$ height of the valve, $\mathrm{W}=$ width of the valve.

\begin{tabular}{lllll}
\hline Dimensions. & $\mathrm{V}$ & $\mathrm{L}$ & $\mathrm{H}$ & $\mathrm{W} / 2$ \\
\hline MGM-6853X & $\mathrm{R}$ & 26.2 & 18.5 & 3.9 \\
MGM-6850X & $\mathrm{L}$ & 13.0 & 11.1 & 1.5 \\
MGM-6851X & $\mathrm{L}$ & 11.6 & $? 6.0$ & 1.1 \\
FSL 550117 & $\mathrm{L}$ & 9.8 & 7.3 & 1.0 \\
MGM-6852X & $\mathrm{R}$ & 8.2 & 4.9 & 1.2 \\
\hline
\end{tabular}

Table 5. Dimensions and type of the valve in Sluha kosoviensis (Barrande, 1881d).

Abreviations: $\mathrm{V}=$ valve $(\mathrm{R}=$ right valve, $\mathrm{L}=$ left valve, $\mathrm{A}=$ articulated specimen $), \mathrm{L}=$ length of the valve, $\mathrm{H}=$ height of the valve, $\mathrm{W}=$ width of the valve.

\begin{tabular}{lllll}
\hline Dimensions. & $\mathrm{V}$ & $\mathrm{L}$ & $\mathrm{H}$ & $\mathrm{W} / 2$ \\
\hline FSL 550162 & $\mathrm{L}$ & 24.4 & 17.2 & 1.2 \\
MGM-6847X & $\mathrm{L}$ & 22.2 & 18.5 & 3.1 \\
& & & & \\
\hline
\end{tabular}

Table 6. Dimensions and type of the valve in Phestia? sp.

Abreviations: $\mathrm{V}=$ valve $(\mathrm{R}=$ right valve, $\mathrm{L}=$ left valve, $\mathrm{A}=$ articulated specimen $), \mathrm{L}=$ length of the valve, $\mathrm{H}=$ height of the valve, $\mathrm{W}=$ width of the valve.

\begin{tabular}{lllll}
\hline Dimensions. & $\mathrm{V}$ & $\mathrm{L}$ & $\mathrm{H}$ & $\mathrm{W} / 2$ \\
\hline FSL 550115 & $\mathrm{R}$ & 20.2 & 10.4 & 1.5 \\
\hline
\end{tabular}


Table 7. Dimensions and type of the valve in Modiolopsis sp.

Abreviations: $\mathrm{V}=$ valve $(\mathrm{R}=$ right valve, $\mathrm{L}=$ left valve, $\mathrm{A}=$ articulated specimen $), \mathrm{L}=$ length of the valve, $\mathrm{H}=$ height of the valve, $\mathrm{W}=$ width of the valve.

\begin{tabular}{lllll}
\hline Dimensions. & $\mathrm{V}$ & $\mathrm{L}$ & $\mathrm{H}$ & $\mathrm{W} / 2$ \\
\hline MGM-6871X & $\mathrm{L}$ & 51.2 & 30.8 & 8.4 \\
MGM-6873X & $\mathrm{L}$ & $? 49.1$ & 28.4 & 7.1 \\
MGM-6854X & $\mathrm{L}$ & 44.8 & 23.9 & 6.0 \\
MGM-6874X & $\mathrm{R}$ & 39.7 & 22.0 & 4.1 \\
MGM-6855X & $\mathrm{R}$ & 37.2 & 26.0 & 3.2 \\
MGM-6870X & $\mathrm{R}$ & 35.0 & 19.1 & 1.9 \\
MGM-6872X & $\mathrm{L}$ & $? 31.5$ & 17.2 & 1.9 \\
MGM-6865X & $\mathrm{L}$ & 26.2 & 14.7 & 2 \\
MGM-6867X & $\mathrm{L}$ & 21.0 & 16.1 & 2.5 \\
MGM-6857X & $\mathrm{L}$ & - & 25.2 & 5.0 \\
\hline
\end{tabular}

Table 8. Dimensions and type of the valve in Dceruska sp.

Abreviations: $\mathrm{V}=$ valve $(\mathrm{R}=$ right valve, $\mathrm{L}=$ left valve, $\mathrm{A}=$ articulated specimen $), \mathrm{L}=$ length of the valve, $\mathrm{H}=$ height of the valve, $\mathrm{W}=$ width of the valve.

\begin{tabular}{lllll}
\hline Dimensions. & V & L & H & W/2 \\
\hline MGM-6842X & A & 51.2 & 26.3 & 7.7 \\
MGM-6861X & L & 41.2 & - & - \\
\hline
\end{tabular}

Table 9. Dimensions and type of the valve in Ambonychia aff. magna.

Abreviations: $\mathrm{V}=$ valve $(\mathrm{R}=$ right valve, $\mathrm{L}=$ left valve, $\mathrm{A}=$ articulated specimen $), \mathrm{L}=$ length of the valve, $\mathrm{H}=$ height of the valve, $\mathrm{W}=$ width of the valve.

\begin{tabular}{lllll}
\hline Dimensions. & V & L & H & W/2 \\
\hline MGM-6858X & L & 92.1 & 56.8 & 10.2 \\
\hline
\end{tabular}

Table 10. Dimensions and type of the valve in Ambonychia sp.

Abreviations: $\mathrm{V}=$ valve $(\mathrm{R}=$ right valve, $\mathrm{L}=$ left valve, $\mathrm{A}=$ articulated specimen $), \mathrm{L}=$ length of the valve, $\mathrm{H}=$ height of the valve, $\mathrm{W}=$ width of the valve.

\begin{tabular}{lllll}
\hline Dimensions. & $\mathrm{V}$ & $\mathrm{L}$ & $\mathrm{H}$ & $\mathrm{W} / 2$ \\
\hline MGM-6866X & $\mathrm{A}$ & 45.8 & 22.2 & 11.0 \\
\hline
\end{tabular}

Table 11. Dimensions and type of the valve in Cleionychia transversa (Portlock, 1843)

Abreviations: $\mathrm{V}=$ valve $(\mathrm{R}=$ right valve, $\mathrm{L}=$ left valve, $\mathrm{A}=$ articulated specimen $), \mathrm{L}=$ length of the valve, $\mathrm{H}=$ height of the valve, $\mathrm{W}=$ width of the valve.

\begin{tabular}{lllll}
\hline Dimensions. & V & L & H & W/2 \\
\hline MGM-6841X & L & - & - & 10.0 \\
& & & & \\
\hline
\end{tabular}

Table 12. Dimensions and type of the valve in Cleionychia prisca (Portlock, 1843).

Abreviations: $\mathrm{V}=$ valve $(\mathrm{R}=$ right valve, $\mathrm{L}=$ left valve, $\mathrm{A}=$ articulated specimen $), \mathrm{L}=$ length of the valve, $\mathrm{H}=$ height of the valve, $\mathrm{W}=$ width of the valve. 


\begin{tabular}{lcccc}
\hline Dimensions. & V & L & H & W/2 \\
\hline MGM-6864X b & L & - & 34.8 & - \\
MGM-6864X a & A & - & - & 19.1 \\
MGM-6875X & L & - & - & 10.2 \\
MGM-6856X & R & - & - & 9.0 \\
\hline
\end{tabular}

Table 13. Dimensions and type of the valve in Cyrtodonta sp.

Abreviations: $\mathrm{V}=$ valve $(\mathrm{R}=$ right valve, $\mathrm{L}=$ left valve, $\mathrm{A}=$ articulated specimen $), \mathrm{L}=$ length of the valve, $\mathrm{H}=$ height of the valve, $\mathrm{W}=$ width of the valve.

\begin{tabular}{lllll}
\hline Dimensions. & V & L & H & W/2 \\
\hline MGM-6863X & L & 89.4 & 53.8 & 15.1 \\
MGM-6859X & R & 73.1 & 52.9 & 18.2 \\
MGM-6869X & A & - & 54 & 17 \\
MGM-6868X & A & - & 53 & 22 \\
\hline
\end{tabular}

Table 14. Dimensions and type of the valve in Pseudarca? sp.

Abreviations: $\mathrm{V}=$ valve $(\mathrm{R}=$ right valve, $\mathrm{L}=$ left valve, $\mathrm{A}=$ articulated specimen $), \mathrm{L}=$ length of the valve, $\mathrm{H}=$ height of the valve, $\mathrm{W}=$ width of the valve.

\begin{tabular}{lllll}
\hline Dimensions. & V & L & H & W/2 \\
\hline FSL 550155 & R & 82.1 & 19.8 & $?$ \\
\hline
\end{tabular}

